\author{
UNIVERSIDADE DE SÃO PAULO \\ FACULDADE DE FILOSOFIA LETRAS E CIÊNCIAS HUMANAS \\ DEPARTAMENTO DE SOCIOLOGIA \\ PROGRAMA DE PÓS-GRADUAÇÃO EM SOCIOLOGIA
}

FLAVIA BRANCALION

Tornar-se compositor: a construção do modernismo musical e o processo de institucionalização da música de concerto em São Paulo (1920-1950)

SÃo PAULO

2016 


\section{Tornar-se compositor: a construção do modernismo musical e o processo de institucionalização da música de concerto em São Paulo (1920-1950)}

Dissertação de Mestrado apresentada ao Programa de Pós-Graduação do Departamento de Sociologia da Faculdade de Filosofia, Letras e Ciências Humanas da Universidade de São Paulo, para a obtenção de título de Mestre em Sociologia

Orientador: Prof. ${ }^{\circ}$ Dr $^{\circ}$ Fernando Antônio Pinheiro Filho

SÃO PAULO 
Autorizo a reprodução e divulgação total ou parcial deste trabalho, por qualquer meio convencional ou eletrônico, para fins de estudo e pesquisa, desde que citada a fonte.

Catalogação na Publicação

Serviço de Biblioteca e Documentação

Faculdade de Filosofia, Letras e Ciências Humanas da Universidade de São Paulo

B816t

Brancalion, Flavia

Tornar-se compositor: a construção do modernismo musical e o processo de institucionalização da música de concerto em São Paulo (1920-1950) / Flavia Brancalion ; orientador Fernando Antônio Pinheiro Filho. - São Paulo, 2016.

$94 \mathrm{f}$.

Dissertação (Mestrado)- Faculdade de Filosofia, Letras e Ciências Humanas da Universidade de São Paulo. Departamento de Sociologia. Área de concentração: Sociologia.

1. Compositores paulistas. 2. Música de concerto brasileira. 3. Modernismo. 4. Sociologia da cultura. I. Pinheiro Filho, Fernando Antônio, orient. II. Título. 

BRANCALION, Flavia. Tornar-se compositor: a construção do modernismo musical e o processo de institucionalização da música de concerto em São Paulo (1920-1950). Dissertação apresentada ao Programa de Pós-Graduação em Sociologia da Faculdade de Filosofia, Letras e Ciências Humanas para obtenção do título de mestre em Sociologia.

Data de exame da dissertação:

\section{BANCA EXAMINADORA:}

Prof. Dr. Instituição:

Ass.:

Prof. Dr. Instituição:

Ass.:

Prof. Dr. Instituição:

Ass.: 


\section{RESUMO}

Esta trabalho trata do processo de institucionalização da música de concerto em São Paulo entre 1920 e 1950, tendo por fio condutor as trajetórias cruzadas de compositores que se engajaram no projeto modernista, com mais ou menos intensidade, e colhendo dele mais ou menos frutos. Parte-se do estabelecimento dos perfis morfológicos concernentes às origens sociais desses agentes a fim de compreender as condições de possibilidade de carreiras voltadas à criação musical. Em seguida, redesenha-se o estabelecimento de interdependências que se desenrolaram em certos círculos de sociabilidade nos quais as experiências modernistas se forjaram. Por fim, esboça-se os rendimentos do modernismo musical na fatura das gerações seguintes de compositores.

Palavras-chave: Compositores paulistas - Música de concerto brasileira - Modernismo - Música Nacionalista - Sociologia da Cultura. 


\section{ABSTRACT}

This essay strives to shed a light on the institutionalization of concert music in São Paulo along the 1920s and 1950s through crossed itineraries of those composers who took part in modernism, whether well-succeeded or not. In order to understand the settings that made their careers possible, a morphological analysis is armed. Then, we set out to redraw the interdependencies which were unfolded among the circles of sociability where the experiences of the modernists were shaped. Finally, we put in perspective the revenues derived from it in the next generation of composers.

Keywords: Composers from São Paulo - Brazilian Concert Music - Modernism - Nationalism in music - Sociologie of Culture 


\section{ÍNDICE}

AGRADECIMENTOS 4

INTRODUÇÃO 6

PARTE I - Os caminhos para a composição: o caso de Camargo Guarnieri

Capítulo 1 - A década de 1920: busca pela formação e a construção da vocação

Capítulo 2 - As décadas de 1930 e 1940: política modernista negociada

PARTE II - Desdobramentos

Capítulo 3 - A década de 1950: modernidades em busca de uma tradição

CONCLUSÃO

BIBLIOGRAFIA

87 


\section{AGRADECIMENTOS}

Agradeço especialmente

Os funcionários da Secretaria de Pós-Graduação do Departamento de Sociologia pelo auxílio e organização.

As funcionárias do Arquivo do IEB, sempre muito atenciosas. Também de lá, a professora Flávia Toni.

A CAPES/CNPq pelo apoio financeiro a esta pesquisa.

Meus colegas da pós que ingressaram no mestrado em 2014, com os quais pude enxergar melhor e mais realisticamente aquele projeto de pesquisa inicial tão... otimista e inventivo, digamos, que eu mal sabia como começar.

Certamente também não saberia acabá-lo se não fossem as iluminadoras ideias do meu orientador, professor Fernando Pinheiro Filho, em quem admiro a sensibilidade intelectual para depurar questões interessantes do borrão do material, desenvolvê-las com confiança e precisão - e depois de tudo isso, ainda transmiti-las de maneira invejavelmente objetiva na fala ou na escrita.

O professor Sérgio Miceli e o brilhante amigo Maurício de Bonis pelos apontamentos decisivos no exame de qualificação que me ajudaram a seguir com a pesquisa.

Os colegas alunos e os professores do Departamento de Sociologia, Luiz Jackson e Ruy Braga e Carlos Kater, do Departamento de Música, pelas discussões envolventes travadas em suas aulas.

O mestre Willy Corrêa de Oliveira pelas horas de boa conversa franca e instantes de entrevista.

Os colegas do grupo de estudos de Sociologia da Cultura por terem lido com generosidade um trecho deste trabalho e me estimulado na reta final.

Por outro lado, não poderia ter chegado à última linha dessa dissertação sem o apoio, ou melhor seria o andaime, dos grandes amigos que fiz ao longo desses anos de "sofrência".

Brian Fuentes Requena, entusiasta do bronzeamento dos pulmões nos intervalos das aulas, sempre nos fez economizar com psicólogos ao exortar aquelas qualidades que duvidávamos ter - 
que provavelmente não temos mesmo. Obrigada por insistir e nos fazer recuperar a autoconfiança. Sem você eu realmente não teria dado conta.

Marcello Pocai Stella, apreciador de karaokê e doces à base de ovos; embora não fume, tem muitas qualidades, como ser bom prosador de bar, prestativo e carinhoso. E descolado. Pelos instantes de conversas inspiradoras e projetos conjuntos, tudo entre garrafas de vinho ou cerveja, obrigada.

João Victor Kosicki, querido colega de orientação, é um daqueles amigos reconfortantes de se ter... São calorosos e sabem se esquecer de si em conversas, entusiasmar-se e se envolver com as ideias dos outros. E, claro, minha eterna gratidão pelas caronas, porres, telefonemas da Islândia e por me deixar ver o seu florescimento intelectual "a olhos nus". Minha gratidão por tudo, meu amigo.

Dedico este trabalho a minha mãe, Lili, na esperança de despreocupá-la da vida "estranha" que escolhi viver e das músicas de "plin-plin" que resolvi gostar.

Também ao meu querido, admirado, bello, belíssimo pai, Gerson - que insistiu em escrever sua própria dedicatória.

A minha tia Eneida, cujo termo banal "tia" não faz jus ao amor que cultivamos uma pela outra.

Ao Gordo (vulgo "Caio Brancalion”), amado irmão, coautor de tantos atos de delinquência juvenil durante nossa infância - quantos bombons não surrupiamos do mercado...

Ao Caio, meu companheiro e fundador do "Merdismo" (e de dezenas de outras instituições), que por mais inspirador e genial que seja, curiosamente jamais teve razão nas nossas "discussões" sobre música de vanguarda, Tolstói vs Dostoiévski, conjuntura política, louça suja... Enfim.

Em tempo, à memória de Zoë, Hérmès, Gilberto e dos amores do pretérito imperfeito. 


\section{INTRODUÇÃO}

Este trabalho se debruça sobre o itinerário da institucionalização da música de concerto em São Paulo durante as décadas de 1920, 30 e 40, que passa de uma base de sustentação amparada em setores das oligarquias a um modelo de mecenato oficial estatal, concentrando-se especificamente no surgimento de uma geração de compositores dedicada à produção de peças orientadas pelos debates estéticos da "música nacional". Refiro-me aos compositores próximos dos intelectuais modernista da década de 1920, e stes que num esforço crítico de afastamento dos gostos das elites oligárquicas, apesar da dependência de recursos, espaços providos e origem social comum, infundiram a busca de expressões artísticas compassadas com os "novos tempos". Posteriormente, ao longo da década seguinte, o intento contestatório frente a desatualização cultural discriminada passa a prefigurar um amplo plano de políticas públicas às artes a partir do movimento de integração dos intelectuais e artistas modernistas em instâncias de poder, como atesta o engajamento de Mário de Andrade à frente do Departamento Municipal de Cultura entre 1935 e 1938. Tais políticas, possíveis graças ao declínio da oligarquia cafeeira após 29 , representaram um marco de dinamização do meio musical, através da criação de uma rede de instituições fixas de formação e difusão de repertório, embora nem todas tenham durado, ou operado com o mesmo vigor após o mandato. Apesar disso, o projeto modernista foi eficiente em gestar fortes laços de interdependência entre os membros que o levaram a diante, isto é, entre os intelectuais, críticos e jovens músicos, responsáveis por concretizar em ato o modernismo musical idealizado. Decorre dessa relação de mútua dependência, marcadas por divergências e alianças, um tenso espaço de negociação para que os interesses, ambições e p rojetos pessoais se acomodassem. Contudo, a justa apreciação do itinerário institucional só pode se dar através do lastro empírico de trajetórias artísticas produzidas e produtoras desse processo. Camargo Guarnieri, compositor canonizado como um dos principais representantes paulista da referida experiência modernista na música brasileira pela crítica ligada ao movimento, ao lado de Francisco Mignone, nos servirá de linha condutora analítica de um conjunto de questões que culminou num atraso do campo musical em relação à constituição dos demais campos culturais ao cabo do intervalo recortado.

Pretendo, com efeito, traçar os caminhos possíveis, interditos e os ainda por cavar dos agentes do meio musical da época ligados à música de concerto, com destaque ao emblemático caso de Guarnieri. Nesse sentido, é necessário o recurso da comparação, de forma a arquitetar um retrato coletivo composto pela trajetória de outros músicos. Para tanto recorri a material documental, como biografias e autobiografias, que me permitiram localizar recorrências, delinear perfis comuns e incomuns, sem anular a especificidade de cada trajetória, bem como acompanhar os problemas e obstáculos enfrentados pelos músicos na construção de seu itinerário. Assim, pode-se captar e 
esclarecer quais eram os mecanismos sociais presentes na aprendizagem do oficio musical, num primeiro momento, e viabilização da obra, restaurando as configurações sociais que possibilitaram o acesso dos músicos paulistas à composição erudita, até então atividade restrita a músicos da capital do país.

As questões referentes à formação do campo musical no Brasil, sobretudo a consolidação da polarização de agentes em tomo da música de concerto, deu-se notadamente a partir dos primeiros esforços de criação de instituições de formação e difusão musical no século XIX, pelo Império. Da relativa dificuldade em manter conjuntos musicais fixos e centros de ensino musical que dessem conta da formação requerida para a constituição de uma geração de compositores que não dependessem de atividades nos meio da música de divertimento associada aos espaços de sociabilidade ora da elite, ora de setores populares, advém um cenário que se manteria até meados da década de 1930. No contexto da transição entre a Primeira República e a Era Vargas, surgem projetos concretos de dinamização da vida musical em centros de crescente urbanização, como São Paulo, Rio de Janeiro e Porto Alegre. Tais projetos foram engendrados por círculos de intelectuais e artistas que, nos anos 1920, estiveram à frente de agitações culturais fomentadas por elites oligárquicas desejosas de empreender um contraditório processo de modernização do país. Com efeito, o que eram críticas à d esatualização cultural brasileira e à subordinação dos artistas do X IX à estéticas relacionadas ao complexo do colonizado na década de 1920, passa a estruturar um largo plano de políticas públicas às artes com o ingresso dos intelectuais modernistas em instância de poder.

A partir da década de 1930, em São Paulo, cidade privilegiada no recorte espacial desta pesquisa, o e ngajamento no âmbito municipal do D epartamento de Cultura operado por Mário de Andrade lança as bases da ampliação do processo incipiente de institucionalização e diferenciação das atividades musicais. Através de várias iniciativas logra conferir maior vitalidade ao meio musical, sendo fundamental neste processo, além das iniciativas institucionais, a colaboração estabelecida com jovens músicos que intentavam viabilizar carreiras na área de criação musical. Dessas relações de interdependência entre compositores e intelectuais modernistas, crivadas por tensões, divergências, apoio contingencial, rupturas, etc, gesta-se a dinâmica do modernismo musical. Os músicos não seriam meros agentes passivos operadores das mudanças almejadas, uma vez que eles próprios tinham seus projetos estéticos, mas ativos formuladores do modernismo, porquanto tinham de colocá-lo em prática; seja elegendo do arcabouço construído pelos intelectuais de tradições brasileiras legítimas elementos expressivos que deveriam ser formalizados em peças, seja na condução dos órgãos musicais dos quais forma incumbidos.

O texto Ensaio sobre a música brasileira, escrito em 1928 por Mário de Andrade é comumente considerado um guia de orientação estética à criação da música verdadeiramente 
brasileira, sobretudo em relação ao material musical. Isto é, aquela distante tanto do g osto "cosmopolita" por óperas italianas da elite oligárquica paulistana, quanto despida de exotismos e lugares-comuns, aos quais Villa-Lobos incorria, segundo o autor. Pode-se, todavia, entrever no texto um intento mais amplo e ambicioso, qual seja, a inserção da música erudita num projeto de construção nacional do Brasil, assim como diretrizes para um projeto de "modernização" do meio musical, prevendo a urdidura de referenciais à música brasileira a partir de suas tradições. Para tanto, além de fomentar instituições de formação e divulgação de repertório e garantir a profissionalização de criadores e intérpretes, trata-se de formar um grupo de compositores "modernos", norteados por questões estéticas da fonte do material musical. Fica claro, portanto, que desde o início o ensejo de modernizar o meio musical esteve vinculado ao projeto de forjar um conjunto de representações sociais emblemáticas do nosso, de uma tradição brasileira a ser inventada pelos próprios modernistas a partir da eleição de elementos legítimos das produções musicais "populares" de regiões interioranas, num primeiro momento, do país. Tais representações sociais orientam a es colha das fontes "folclóricas", termo que se cristaliza no meio musical da época, entre os compositores e intelectuais.

Apesar do s ubstrato institucional do c ampo musical ter se ampliado, a gestão de Mário de Andrade não foi suficiente para garantir as condições necessárias à formação de compositores, nem de manter a profisssionalização da música de concerto - um tanto limitada à nomeações de compositores para dirigirem os novos conjuntos musicais criados, e ingressarem no qua dro docente do Conservatório Dramático Musical. A dependência do projeto modernista em relação aos desenlaces dos conflitos e disputas do c ampo político conformou os rumos dos principais compositores brasileiros da época, conforme veremos no primeiro capítulo. Em comum às trajetórias, por conta do atrelamento ao campo do poder, passível de fragilizar as condições de auferimento de colocações no campo musical, fica em evidência a necessidade de estabelecer redes alternativas de colaboradores, vinculados a outras instâncias de poder e sociabilidade, nacionais e internacionais.

Pretendo, com efeito, traçar os possíveis caminhos dos compositores eruditos em São Paulo, sempre trilhados a fim de buscar condições de formação musical e viabilização da obra. Entre as décadas de 1930 e 1960, o polo erudito do campo musical ganha corpo institucional em relação às condições que Carlos Gomes, Henrique de Mesquita e Francisco Braga encontraram no século XIX e início do xx. Tais décadas representam um marco na dinamização do meio da música de concerto no Brasil com a criação de uma rede de instituições de difusão e formação, transição operada pela

estruturação do mecenato oficial encarnada nas políticas públicas para a arte do getulismo, bem como, no âmbito paulista, da direção de Mário de Andrade no Departamento de Cultura da prefeitura. Esta rede de instituições, mantida sob a guarida do Estado e geri da pela dinâmica que se depreende das relações de interdependência entre intelectuais dos círculos de poder e os músicos encarregados, 
realiza a i mplementação do projeto do mecenato estatal. Contudo, nitidamente atravessado pelas tensões entre os intelectuais e músicos, pois estes também partilhavam de poder, ao passo que ensejavam se afirmar como artistas e realizar a contento seus projetos estéticos, e por vezes políticos, o espaço institucional criado abre novas possibilidades de posições no campo musical, novos caminhos possíveis aos compositores. Entre tais possibilidades surgem as primeiras experiências especulativas de vanguarda, ao final da década de 1930, interessadas em repensar o material musical e sua fonte folclórica, movimento que entraria em choque com parte dos compositores estabelecidos. As experiências dos grupos de compositores como o pioneiro Música Viva, de meados da década de 1930 e de 1940, e o Música Nova de 1963, fixaram na história do campo as primeiras reelaborações e rupturas com as preocupações do modernismo musical de Mário de Andrade. Do primeiro para o segundo grupo, como veremos, há grandes diferenças institucionais e a extensão dos trabalhos de produção para o ambiente do mercado publicitário, bem como da música popular.

Pensei, portanto, em organizar a dissertação em três capítulos, um para cada experiência dos grupos de compositores tidos, conforme discutido, como fundamentais à formação do polo erudito do campo musical brasileiro, seguindo a ordem cronológica de seus inícios:

No primeiro capítulo pretendo destrinchar alguns dos aspectos decisivos à trajetória de compositores bem-sucedidos que encontraram no âmbito do Estado o caminho para a viabilização de seus projetos artísticos. Neste sentido, Camargo Guarnieri é tomado como ilustração bastante representativa dessa figura, ao ser cotejado com outras trajetórias de compositores paulistas em suas respectivas tentativas de lograr boa formação técnica e colocações profissionais num meio musical marcado pela precária institucionalização do ensino e indiferenciação entre as diversas atividades musicais empreendidas no mercado popular de divertimento. Limitando-me ao período compreendido entre as décadas de 1920 e 1950, da gestação e implementação do p rojeto modernista dirigido à música, destacarei alguns elementos característicos do campo musical da época, especificamente do polo erudito. Tal caso será examinado à luz de suas redes de relações estratégicas e interdependências com os patronos do Estado, o círculo modernista estabelecido na imprensa e em órgãos públicos e até mesmo com a política de "boa vizinhança" orientadora do panamericanismo musical e respaldada pelos interesses do mercado da música sinfônica dos Estados Unidos. Este capítulo é o mais desenvolvido neste texto de qualificação, de forma que

pretendo ainda completá-lo com estudos sobre aspectos musicais de cada período, para além dos poucos momentos em que aparecem no atual capítulo. Ainda faltaria, a meu ver, um último item a respeito do esforço de Guarnieri, durante a década de 1950, de formar uma escola de composição, já que as preocupações com um legado a ser deixado parecem acometê-lo de forma mais peremptória nesse período. 
O segundo capítulo, a ser completamente escrito, ensejaria compreender o que significou o projeto de Hans-Joachin Koellreutter para o campo musical brasileiro, sobretudo as tentativas de justificá-lo através de uma elaboração própria de alguns elementos dos textos sobre música de Mário de Andrade, persistindo numa interpretação bastante particular em relação as de outros criadores, críticos e musicólogos, seguidores já consagrados enquanto tais dos princípios do Ensaio. A despeito da tentativa de se integrar ao campo musical via adesão crítica ao modernismo nacionalista, Koellreutter reaviva a tensão em torno da questão do material musical, ensinando a seus alunos alguns procedimentos serialistas da Segunda Escola de Viena - procedimentos estes que foram utilizados por Cláudio Santoro, Eunice Catunda, Edino Krieger e César Guerra-Peixe, seus principais discípulos no grupo Música Viva, de forma bastante livre e particular a c ada um dos citados. Apesar de não aplicados com ortodoxia, tais procedimentos entraram em confronto com a posição mais legítima no campo musical, na época em que Villa-Lobos já gozava de seu lugar no panteão dos compositores brasileiros do na cionalismo modernista. Contudo, o que determinou a rigor o desmantelamento do grupo foi a ruptura de seus integrantes que participavam do PCB, por conta das diretrizes estéticas do Secretário de Cultura de Stálin, Andrei Zhdanov. Com efeito, os militantes do PCB endossam as críticas feitas por Zhdanov ao caráter degenerado das tendências "atonalistas" e, por sua vez, retomam a pesquisa do material folclórico. Percebe-se que neste momento, de hegemonia do nacionalismo, os discursos justificativos dos projetos musicais se investem de teor político, especificamente alinhado à esquerda, e as disputas estéticas se lastreiam em posturas autoproclamadas marxistas, de modo a se distinguirem daquilo que consideravam nacionalismo ufanista, empreendido por compositores atrelados ao Estado.

O terceiro capítulo, aqui apresentado em forma de esboço, deter-se-á sobre o retomo das propostas de atualização da linguagem musical, suscitadas antes pelo Música Viva e retomadas pelos compositores do grupo Música Nova de Santos/São Paulo, no início dos anos 1960. O compassamento com algumas tendências da vanguarda europeia congregadas nos cursos de verão de Darmstadt, reúne circunstancialmente um grupo de compositores, conhecidos entre si da movimentação nos círculos de artistas do Partido Comunista Brasileiro. Reconhece-se esta propriedade comum aos dissidentes do Música Viva; no entanto, os mais jovens compõe uma nova geração do meio partidário, crítica das tendências nacionalistas de esquerda e de direita, diferença

que se converte em tensão geracional formalizada em novas demandas expressivas, questões estéticas e problemas de composição. Dentre estes problemas, retoma-se o debate da memória do material musical, tão presente nas inflexões estéticas e c ontradições da obra de Willy Corrêa de Oliveira, debate que se perdera antes pelo consenso tácito do interesse pelo material folclórico entre os compositores vinculados aos dirigentes do c ampo político. Serão, pois, analisadas futuramente na dissertação enquanto expressões da experiência social do compositor, situado nas disputas específicas 
do campo musical, peças representativas das inflexões estéticas dentro do conjunto da obra. Afinal, uma vez comparadas com peças diferentes, produzidas por compositores de outras orientações estéticas, podem desvelar o estado dos debates estéticos representativos das posições configuradas no campo musical da época, que movem a produção. 


\section{CAPÍTULO 1}

\section{A década de 1920: busca pela formação e a construção da vocação}

Antes de mais nada, esbocemos em linhas gerais o cenário musical erudito mais especializado da cidade no início do século $^{1}$ a fim de visualizá-lo melhor. Nas duas primeiras décadas do século XX, as oligarquias ligadas ao café erigiram espaços de sociabilidade da alta sociedade, como o Teatro Municipal (de 1911), inscritos num projeto de urbanização de feições europeizantes, ora levado pelo poder público, ora por associações privadas, ora por um indistinto vínculo entre ambos - O Conservatório Dramático e Musical de São Paulo (1906), o Pensionato Artístico do Governo do Estado de São Paulo (1912), o Centro Musical São Paulo (1913) e a Orquestra de Concertos de São Paulo (1920) são parte do mesmo intento. Atinadas a tal gosto, as elites se reuniam em torno das óperas organizadas pelas companhias estrangeiras da Temporada Lírica e concertos promovidos pela Sociedade de Cultura Artística (1912) em iniciativas esparsas do mecenato oligarca, conjunto de atividades que fazia às vezes de um mercado da música erudita local, que melhor se caracterizaria como extensão do mercado europeu em países da periferia dos centros da "música Ocidental", geralmente durante os intervalos das principais temporadas de lá. Contudo, os instrumentistas e regentes paulistas mordiscavam um ou outro concerto da SdCA, auferiam um ou outro posto temporário junto às companhias de fora, enquanto o mercado da música erudita era largamente ocupado por artistas estrangeiros em tournées comissionadas por empresários italianos, como Walter Mocchi. Em paralelo, os músicos locais encontravam acolhida na pulsante cena de divertimentos da cidade, tanto de convívio dos setores médio, quanto de entretenimento e sociabilidade das elites, isto é, dos bordéis, festas e bares, até cinemas, cafés, lojas de música, hotéis, apresentações privadas em residências e clubes, etc. A constante circulação entre os ambientes de extração social variada conjugada à incipiente profissionalização dos músicos, estimulou certa indiferenciação das funções, de modo que os agentes fossem requisitados a desenvolver suas habilidades de intérprete, regente e compositor de acordo com as oportunidades que lhes surgissem, conferindo certa versatilidade aos músicos.

Nos anos 20, a extração social dos músicos era pouco diversificada entre aqueles que circulavam nos meios da elite paulistana, e que detinham as habilidades específicas para tratar do repertório erudito. Havia dois grupos principais, cujas origens remetem ao processo de urbanização de São Paulo do final do XIX - do qual o afluxo de imigrantes, sobretudo italianos, e a riqueza das famílias produtoras de café foram determinantes para a configuração cultural da cidade:

1 Para se ter uma visão mais completa do cenário musical da cidade na virada e início do século, ver os trabalhos de José Geraldo Vinci de Moraes (1995, 2000) Denise Sella Fonseca (2014), Virgínia de Almeida Bessa (2012), Alberto Ikeda (1989) e Nicolau Sevcenko (1992). 
“De fato, havia grande concentração de italianos na cidade que, em 1897, 'superavam numericamente os brasileiros na proporção de dois para um', segundo o pesquisador Richard Morse (1970:240). Entre estes, existiam os mais variados níveis socioeconômicos, desde o operário sem qualquer qualificação profissional a grande comerciante e o industrial. A provinciana cidade, que em 1886 contava com aproximadamente 45.000 habitantes, já em 1920 tinha praticamente 600.000 habitantes, isto, em grande parte, devido à vinda de grandes levas desses imigrantes. Assim, a contribuição destes se fez nos vários setores da sociedade, e de maneira significativamente importante no campo da música, como se vê desde 1885 com as atividades do célebre professor e promotor musical Luigi Chiaffarelli (1856 1923) e com as presenças, na cidade, da Banda de Música Bersaglieri [...] em concerto no Circolo Italiano Recreativo - e da Banda Ettore Fieramosca, de atuação destacada na primeira década do século. [...] Os italianos foram responsáveis por boa parte dos empreendimentos musicais na cidade, não só nas atividades própriamente artísticas, mas, ainda no setor de fabricação, importação e comércio de instrumentos musicais, no setor de impressão e comércio de partituras de música e nas atividades empresarial-teatrais. Isto, evidentemente, acrescentado das presenças de inúmeras companhias italianas itinerantes de ópera e operetas que, anualmente aqui vinham completar suas temporadas. [...] No setor comercial de instrumentos, e partituras musicais, grande parte das iniciativas no início do século atual deveu-se aos italianos, como se percebe em qualquer consulta aos jornais e revistas da época [citação de anúncios referentes a tais iniciativas: Fábrica de Mandolins Napolilitanos, de Vincenzo Pirondi; Casa Fritelli, fábrica de violinos e bandolins; Scavone \&Cia, fábrica de instrumentos em metal e madeira; Fábrica de Pianos Nardelli; A Corda Ideal, de Vito Guaglietta; Casas Bevilacqua \& Cia e Tranquillo Giannini, fábrica de cordas]

Além desses estabelecimentos, na primeira década do século, a cidade contava com as editoras A. Di Franco, Chiafarrelli \& C e José Guzzi, e posteriormente, com a Campassi \& Carmin, Casa Manon (Fachini \& Zanni), Attilio Izzo; Pedro Tommasi, Irmãos Vitale e outras casas que não somente editavam, mas também comercializavam partituras e instrumentos musicais. Em 1930, fazendo parte de uma associação que congregava editores e comerciantes do setor - a Associação Nacional de Editores e Negociantes de Música, ANEM - a cidade contava com 35 estabelecimentos associados, sendo que 22 (63\%) destes tinham proprietários ou sócios italianos ou descendentes destes. [...]

Entre os professores músicos, o destaque dos italianos se verifica já na inauguração dos cursos do Conservatório Dramático e Musical de São Paulo, em 1906. 


\section{[...] Também [...] na fundação do Centro Musical de São Paulo (uma espécie de}

sindicato da categoria), em $1^{\circ}$ de maio de 1913, onde, dos 206 professores relacionados, mais de 70\% tinham sobrenomes italianos; devendo-se levar em conta, ainda, que nesta relação não constaram muitas professoras italianas de piano e de canto, e professores de instrumentos populares como o mandolino (bandolim), a guitarra (violão) e o acordeão.” (IKEDA, 1989b)

Do panorama do mercado musical apresentado, depreende-se logo o primeiro desses dois grupos, ou "polos", que dividem as origens possíveis dos músicos eruditos. O polo da imigração italiana de classe média ou baixa, com origem estrangeira imediata ou descendente de primeira geração, sequiosos por lograr integração social via busca de oferta de colocações apropriadas à qualificação obtida pela educação especializada nas instituições europeias, ou senão na iniciação musical orientada pelos familiares detentores dessa especialização prévia; uma grande parte dos filhos da imigração são primogênitos ou únicos. Este polo encontrou abrigo, com efeito, junto aos interesses de distinção simbólica das oligarquias rurais, dispostas a contratar professores particulares de piano para formar suas filhas na melhor emulação possível de tradições projetadas do "requinte" europeu, convertidas em trunfo social. Entre o grupo dos imigrantes estão Zacarias Autuori, Torquato Amore, Ferrucio Arrivabene, Francisco Murino; Alfério Mignone (pai de Francisco Mignone), Giuliano Bastiani, Guido Rocchi, Giacomo Foschini, Carlos Pagliuchi, Agostinho Cantú e Luigi Chiaffarelli foram professores do CDMSP; o último fundou o Centro Musical de S. Paulo, junto com Savino de Benedictis e Furio Franceschini; entre os filhos de imigrantes musicistas se encontram Alexandre Levy (1864-1892; pai clarinetista francês), Francisco Mignone (1897-1986), Armando Belardi (1898-1989) e Camargo Guarnieri (1907-1993), nenhum deles se limitou a apenas uma especialidade, foram regentes, compositores e intérpretes. Há nomes de destaque na música popular também, como Adoniran Barbosa (João Rubinato), José Rielli (Giuseppe Rielli, nascido na Itália), Paraguassu (Roque Ricciardi), Canhoto (Américo Jacomino), Vadico (Oswaldo Gogliano), Mário Zan (Mario Zandomenighi, nascido na Itália), Sérgio Reis (Sérgio Basini), Toquinho (Antônio Pecci Filho), etc. Neste polo amplamente dominado por homens, há pouquíssimos exemplos femininos, entre eles o da violinista Paulina D'Ambrosio e a compositora Lina Pesce, ambas de família italiana, com percursos diferentes dos seus colegas ${ }^{2}$.

O segundo polo é constituído por membros vinculados às famílias de alto prestígio das elites, sejam das velhas oligarquias rurais, sejam de uma emergente elite industrial de origem

2 Há alguns estudos que mapearam trajetórias de mulheres no meio musical. Entre eles, o cuidadoso trabalho de Dalila Vasconcellos de Carvalho (2012) sobre a construção social das carreiras musicais a partir do recorte de gênero nos casos de Joanídia Sodré e Helza Camêu. A discussão em si é complexa, portanto vamos nos concentrar em desfiá-la de acordo com os nossos objetivos, ou seja, incorporando as indicações de diferença de oportunidades e acesso a caminhos apontadas por Dalila, mas sem nos aprofundarmos neste marcador. 
imigrante. Grande parte são mulheres, mas há homens também. Entre estes é notável a maioria de rebentos caçulas de famílias em declínio social, filhos dos chamados "primos pobres” (cf. MICELI, 2001:105), que mobilizaram seu capital social de proximidade com as camadas dominantes da política e da intelectualidade para viabilizar carreiras, lançando mão da rede de contatos familiar. Entre exemplos estão Guiomar Novaes (1895-1979), Antonietta Rudge (1885-1974) e Souza Lima (1898-1982), todos reconhecidos pianistas, embora Souza Lima tenha exercido atividades de composição (com menos prestígio) e regência.

A ligação entre os dois grupos e as frações dirigentes compreendia o mesmo caráter de dependência mútua que se dava entre o poder político e controle de recursos a que as elites sociais e políticas garantiam e o conhecimento técnico da linguagem e produção de padrões de gosto dos imigrantes. Exemplos claros dessa relação de interdependência perpassam a fundação da Sociedade de Cultura Artística por Freitas Valle, Nestor Pestana, Ramos de Azevedo e Vicente de Carvalho, junto a alguns artistas, entre eles os músicos Agostino Cantù, Furio Franceschini, Zacarias Autuori, Felix de Otero, José Wancolle, Luiz e Maurício Levy, o irmão mais velho de Souza Lima e Luigi Chiaffarelli. Este último, trazido para o Brasil em 1883 por iniciativa de um grupo de fazendeiros para que ensinasse piano às moças, foi responsável pela maior escola de pianistas da época, cuja lista de discípulos totaliza 509, 469 mulheres e 40 homens ( $92 \%$ mulheres, 8\% homens), e contém inúmeros sobrenomes poderosos: Prado, Rebouças, Homem de Mello, Siqueira Campos, Toledo Piza, Tobias de Aguiar, Lacerda Franco, Rudge, Paes de Barros, Matarazzo, Klabin, França Pinto, Penteado, Pujol, Anhaia, Mesquita, Rodrigues Alves, entre filhas de presidentes da República, do Estado e do prefeito da cidade (cf. BINDER, 2013). Ademais, deu aulas para as mais importantes figuras do piano da época, como Guiomar Novaes, Magda Tagliafferro, Antonietta Rudge e Souza Lima, bem como participou da fundação das principais instituições musicais (além da SdCA, CMSP e CDMSP)

Há alguns elementos em comum nas trajetórias, independente da origem social associada a um dos polos, mas que, de acordo com estes, se apresentam de formas diferentes aos agentes. A circulação entre os ambientes das classes altas, no caso dos músicos que se especializaram no repertório erudito, foi imprescindível em todos os casos examinados aqui. Não nos esqueçamos de que tais espaços eram, antes de tudo, espaços de sociabilidade de grupos sociais, e que portanto forneciam não só uma gama de possibilidades de viabilização de formação e carreiras. Cada um com sua história e especificidade, deram relevo a ideias e projetos, condicionaram tensões, alianças e rupturas que marcaram o percurso desses grupos e seus agentes. Nas duas primeiras décadas os lugares mais recorrentes nas trajetórias examinadas, além dos já citados, foram os salões das famílias abastadas, como a Vila Kyrial do senador Freitas Valle (frequentada por quase todos os 
nomes mais e menos importantes da época, abrangendo todos os músicos que se ligaram ao movimento modernista, e antes dele, como Carlos Gomes); a residência dos Amaral (importante para Souza Lima), a residência de Olívia Penteado, etc. Percebe-se que havia espaços fixos de circulação das altas rodas da elite social e política que serviram de palco para a sociabilidade de caráter cosmopolita, passível de incorporar os artistas que correspondessem aos anseios de distinção simbólica dos mecenas, como no caso dos pianistas; contudo, tais espaços também atraíram figuras menos identificadas aos valores artísticos tradicionalistas, agentes que se serviram de maneira ambígua do que queriam combater simbolicamente, no caso dos músicos que se aproximaram dos intelectuais modernistas e enveredaram para uma carreira na composição.

Outro elemento em comum é o envolvimento dos pais, ou irmãos, com a música, cujo tipo e grau é fundamental tanto para a orientação artística e a construção do tipo de "vocação", que em parte é "herdada" e portanto diferente entre os dois polos, quanto determinante à inserção no meio musical. "Pois quando os pais são músicos profissionais (instrumentistas, compositores ou professores de música) (...) transmitem aos filhos o ofício musical, isto é, oferecem um modelo de atuação no meio que significa muito mais do que ensinar um instrumento; trata-se de aparelhar os herdeiros para entrarem no jogo social em vigor no universo em questão. Em alguns casos, são os(as) irmãos(ãs) a desempenharem este papel” (CARVALHO, 2012: 79), como o caso de Mário de Andrade (formado em piano no CDMSP) e Souza Lima, dos quais os irmãos forneceram modelos profissionais "masculinos" de pianistas em meio à "regra" de destino feminino.

Cada um dos polos genericamente apresentados aqui, combinados às condições institucionais da época, engendraram diferentes potencialidades de itinerários, voltagens de ambição artística e experiências estéticas. Em meio a tantas personagens o movimento modernista de 22 encontra diversos níveis de adesão e envolvimento, sobretudo entre os filhos da imigração e os intérpretes oriundos das famílias tradicionais, estes responsáveis por levar adiante a programação musical da Semana de Arte Moderna, geralmente executando peças modernas, combinadas a peças do repertório mais tradicional. Como se sabe, o único compositor brasileiro a ter peças interpretadas foi o carioca Villa-Lobos ${ }^{3}$. Os músicos paulistas mais jovens haveriam de participar do movimento mais tarde, em iniciativas da década de 1930, porquanto estavam na época cavando caminhos para se formar na cidade ou no exterior, sobreviver de música no mercado de divertimento, dando aulas particulares ou tentando compor operetas e o que mais agradasse seus protetores. As possibilidades institucionais em relação à formação e colocação profissional são comuns aos mais jovens, portanto se evidenciarão ao elaborarmos um retrato coletivo composto pelos itinerários de alguns desses

3 Ver WISNIK, 1977. 
protagonistas do modernismo. Destarte, tracemos a trajetória emblemática de "sucesso" de Guarnieri como um "fío guia", que conseguiu não só se tornar compositor de música de concerto, como se consagrou um dos mais importantes compositores "modernistas" pela crítica ligada aos pares do movimento; no entanto, o quadro de caracterização geracional não estaria completo se, em paralelo, deixássemos de cotejar outras trajetórias "menos louvadas" pela crítica, especialmente o caso de Souza Lima, músico que não logrou reconhecimento pelos pares modernistas para seu projeto de composição, tendo sido fixado pela historiografia como grande concertista e, por vezes, regente.

Mozart Camargo Guarnieri nasceu em 1907 e permaneceu até os 15 anos em sua cidade natal, Tietê, interior de São Paulo. O pai, Miguel Guarnieri, imigrante italiano pobre, flautista, trabalhou como barbeiro a fim de garantir a subsistência da extensa prole de nove. A mãe, Géssia de Arruda Camargo, rompe com sua família tradicional de fazendeiros paulistas abastados, casando-se contra a vontade dos pais, movimento que lhe impingiu declínio social e material. Ambos instrumentistas amadores com boa educação musical, ensinaram rudimentos de teoria da música e piano ao primogênito - enquanto este ajuda o pai na barbearia, interrompendo os estudos regulares formais. Tal início de percurso, marcado pela iniciação musical precoce no ambiente familiar, orientada por parentes ativos neste começo, é típico entre as condições reconhecidas de formação e materialização das vocações artísticas. Instila-se desde cedo o modelo vocacional do dom individual e da predestinação por meio de estímulos. Nesse sentido, há o episódio conhecido em que, ainda em Tietê, Guarnieri tem aulas de piano com Virgínio Dias, professor que o desencoraja em seu primeiro esforço criador, a valsa Sonho de Artista, fruto das improvisações que constantemente fazia. A despeito da reprovação do professor, o pai entusiasmado custeia a impressão da partitura em São Paulo, com ajuda financeira de amigos, pela “Off. Musical Mignon”. Diz-se nas biografias do compositor que a peça é elogiada por alguns jornais, e logo comemorada como um pequeno êxito. Embora não haja como comprovar documentalmente a repercussão da crítica, a valsinha criada parece ter reiterado a projeção dos pais acerca do talento, tanto quanto sugerido, pelo nome significativo da peça, a ressonância positiva dessa projeção no filho. Pouco depois do episódio, o bom desempenho ao piano, limitado pelo despreparo dos professores do interior, faz com que a família se mude para São Paulo em 1923, a fim de dar ao filho melhores condições de prosseguir os estudos musicais. A família, portanto, passa a se engajar completamente na construção da carreira do talentoso primogênito, investindo-o de expectativas de alçar melhores posições na sociedade da qual haviam se distanciado ao romper laços com o prestigioso lado materno, da elite quatrocentona.

Não só do flagrante entusiamo nutrido por música, especialmente por ópera - além de 
"Mozart", nomes fortes do gênero foram dados aos demais filhos: Rossine, Belline e Verdi - é possível extrair as razões do grande esforço dos pais de tentar realizar as potencialidades do primogênito, como vimos. Neste caso, assim como em outros, o desejo do pai por fazer do filho promissor aquilo que nunca conseguiu, isto é, viver de música, combina-se a um projeto de ascensão social familiar, busca não rara entre os extratos da imigração italiana de formação especializada, ou semi-especializada, do qual boa parte dos músicos advinha. Em entrevista, Mignone relata o mesmo tipo de esperança do pai, flautista italiano e professor do CDMSP, em relação à sua trajetória: “(...) meu pai acalentava a ideia de fazer do seu filhote um compositor à estampa da trinca Puccini-Mascagni-Leoncavallo” (MIGNONE in MARIZ, 1997:45).

A aposta da mudança para a capital com fins de investimento em formação artística, instiga a ambição de alta voltagem pela qual Guarnieri é reconhecido em torno de uma carreira artística. O compromisso pessoal da entrega total de si à atividade musical presente na concepção vocacional da arte é tão forte diante da incorporação do pacto familiar das aspirações sociais referidas que o conformou, quanto dependente das condições institucionais do meio para se realizar em uma carreira musical. Antes de tratar de tais condições, examinemos ainda a construção dessa vocação.

Apesar do fornecimento de pistas importantes à análise, as biografias ${ }^{4}$ do compositor aderem ao receituário do apagamento dos rastros da construção social do dom, instilando a ideia de uma qualidade excepcional que se revela paulatinamente por meio do reconhecimento dos pares - de forma que o sucesso é a comprovação do carisma, isto é, de que se estava predestinado a ser um artista. Tratam do início do trajeto artístico se servindo de depoimentos tardios de Guarnieri, sem que se possa lastreá-los em documentação sobre sua juventude. Guérios registra o mesmo problema de construção biográfica da juventude de Villa-Lobos, amparada na memória do compositor com poucas fontes documentais, reforçando o adagio do talento precoce, do rigor do pai ao dar as primeiras lições de música ao filho e da vocação para a criação musical (cf. GUÉRIOS, 2009).

No entanto, o risco assumido na mudança para São Paulo parece se justificar por outro elemento, qual seja, a notória trajetória de Villa-Lobos, vinte anos mais velho, cujo estabelecimento de sua reputação já na década de 1920 a partir de estadas em Paris, assoma “como um modelo

4 Publicadas em 2001, as duas biografias sobre Camargo Guarnieri, de Marion Verhaalen, pela Imprensa Oficial, e Maria Abreu, pela Funarte, valem-se de testemunho próprio da amizade (no caso de Abreu, amizade de longa data), documentos do acervo pessoal e declarações tardias do biografado, colaborando com a visada de consagração do "artista nacional", atento à construção de seu legado à época. Na correspondência entre Abreu e Guarnieri, catalogada e mantida no acervo do IEB na USP, fica patente o grau de participação e controle do amigo na elaboração de sua própria biografia, encomendada pela Funarte através de Vasco Mariz, em 1986. Já a musicóloga e pianista norte-americana Marion Verhaalen, que fazia tese sobre a obra pianística do compositor, hospedou-se por anos na residência dos Guarnieri por ocasião da pesquisa (segundo informações do prefácio da edição de 2001) o que gerou laços de amizade. O itinerário contado pelas duas é praticamente igual do ponto de vista das fontes e eventos fundamentais considerados. 
evidente para seu colega mais novo, cujas semelhanças nas biografias não podem ser consideradas mera coincidência” (EGG, 2010:20). A referência da experiência bem-sucedida de Villa-Lobos, que embora tenha advindo do meio musical carioca, encontrou oportunidades de viabilização do início da carreira de compositor junto aos círculos modernistas e seus mecenas perrepistas, pode ter instigado Guarnieri a cogitar as veredas da composição enquanto alternativa emergente à competição acirrada entre a horda de pianistas de origem abastada formados ou nas salas do Conservatório Dramático e Musical, por dois ou três professores de piano que faziam escola, ou em viagens à Europa, geralmente para completarem os estudos no Conservatório de Paris, diretamente na fonte da tradição francesa do padrão de gosto a que as elites buscavam cultivar.

Como em Tietê, abrem uma pequena barbearia anexa à residência da qual mal conseguem tirar o sustento mínimo, apesar do trabalho árduo. Assim, Miguel arranja emprego de regente da orquestra do Cine Bijou, integrando o filho pianista ao conjunto. Pouco tempo depois, Camargo Guarnieri empregou-se na Casa Di Franco, na qual tocava ao piano as partituras solicitadas pelos clientes da loja de música, função que deve lhe ter desenvolvido capacidade de leitura e conhecimento de repertório bastante variado ("popular urbano" e erudito), tanto quanto lhe dado boa noção do gosto e padrão de consumo da clientela de elite. Pois nesta época Marcelo Tupinambá teria recomendado ao jovem pianista desconhecido, que o impressionou por ocasião de uma visita à Casa Di Franco, que fosse estudar com Ernani Braga. Professor de piano no Conservatório Dramático e Musical de São Paulo, compositor e frequentador dos círculos modernistas, Braga apreciou tanto as potencialidades do jovem que se propôs a ensiná-lo de graça. Nesta época, a despeito das atividades musicais de Guarnieri estarem associadas à função de sustento, porquanto trabalhava dia e noite, acumulando empregos na loja citada, num cinema da Avenida Rio Branco e em um bordel no centro da cidade, o que consumia quase todas as horas de seu dia, conseguia tomar as lições de piano e compor por conta própria. Às vezes mostrava o que escrevia ao entusiasmado professor de piano. Esse momento atribulado é retratado nas biografias como de extrema dedicação metódica às atividades. Sob o interessante subtítulo "um operário da boemia", a biógrafa Maria Abreu assim a descreve:

"Não havia tempo para descanso, nem para diversão. Mozart chegava em casa às 6 horas da manhã. Dormia até as nove. Depois, levantava-se para estudar as lições que Ernani Braga Ihe passava. Assim, tinha três horas de sono, separando a música dos bailes das sonatas de Beethoven e das baladas de Chopin. E ainda compunha (...) [tinha] de atender aos cinco empregos (...)” (2001:37)

No caso, o modelo vocacional vincula-se ao ethos ascético, distintivo do profissional em 
relação ao amador, conforme discute Sapiro5; entretanto, diferentemente do caso francês, em que as horas de dedicação à obra são tidas como trunfo da contraposição de Flaubert à elite, a extenuante jornada de atividades, cumprida com abnegação e superação do desgaste físico, parece reforçar menos o caráter da imprevisibilidade associada à criação ${ }^{6}$, do que a regularidade prevista em afazeres de um “operário". Compreender o tipo de afirmação ascética encontrada na vocação musical de Guarnieiri, na medida em que tende a fixar pontos de contato com o universo previsível da profissionalização, passa por voltar à restituição do processo de institucionalização do meio musical paulista, especialmente à abertura de caminhos da composição erudita.

A situação de Guarnieri é emblemática, se considerarmos o estudo de Vinci de Moraes sobre o meio musical, no qual evidencia a incipiente profissionalização dos músicos paulistas nos anos 1930 em relação à situação carioca. Em São Paulo, como era constante a movimentação entre a música erudita e a música popular, os intérpretes cumpriam múltiplos trabalhos, tocando em bailes, acompanhando cantores e em orquestras de rádio ou cinema - como também ocorria no Rio de Janeiro, apesar da cena "erudita" ser mais movimentada. Não raro, combinavam as atividades artísticas com outros ofícios e cargos modestos em empresas públicas ou privadas. (cf.VINCI DE MORAES, 2000). Francisco Mignone, outro compositor do meio paulista, dez anos mais velho que Guarnieri, contou em depoimento que seu pai não conseguia se empregar em teatros e orquestras, somente em pequenos conjuntos de casas de espetáculos, até que mais tarde ocupou o cargo de professor de flauta no Conservatório Dramático, onde matriculou o filho:

"Meu pai era músico e tocava muitos instrumentos; ele perdeu o pai muito cedo e entrou numa instituição onde ensinavam vários instrumentos. Ele tocava trompa, violoncelo, violino, um pouco de piano. A flauta era o instrumento principal, e a mim também ensinou a tocar flauta, colocou-me no piano, ensinou teclado e pequenas coisas, e mesmo de trompa ele me deu algumas aulas. Era quase obrigatório

5 “La conception vocationnelle de l'art n'oppose cependant pas le don au travail ni à l'apprentissage comme en témoignent le nombre incalculable d'heures et l'effort que Flaubert investit dans son oeuvre, ce dont il ne se cache pas dans sa correspondance. Elle est au contraire étroitement liée à un ethos ascétique qui la démarque de l'amateurisme à la fois éclairé et distancié des élites contre lequel il s'affirme.” (2007:7)/ A concepção vocacional da arte não opõe todavia o dom ao trabalho, nem à aprendizagem, como atesta o número incalculável de horas e o esforço investido por Flaubert em sua obra, o qual não esconde em sua correspondência. Ao contrário, está estreitamente ligada a um ethos ascético que a diferencia do amadorismo, a um só tempo claro e distanciado das elites contra as quais se afirma. (tradução livre)

6 "La conception vocationnelle de l'art suppose en effet un investissement total, souvent manifesté à travers la souffrance corporelle ou morale qu'il engendre, et qui vise à se distinguer de l'exécution routinière de tâches prédéfinies, qu'il s'agisse de l'artisanat, de l'académisme ou de la bureaucratie. L'imprédictibilité et l'originalité deviennent alors les principes par lesquels les champs de production culturelle manifestent leur distance par rapport à ces univers et sur lesquels repose le mode de valorisation des oeuvres” (idem)/ A concepção vocacional da arte supõe, com efeito, um investimento total, frequentemente manifestado através do sofrimento corporal ou moral que engendra, e que busca se distinguir da execução rotineira de tarefas pré-definidas, associadas ao artesanato, ao academicismo ou à burocracia. A imprevisibilidade e a originalidade se tornam, então, os princípios pelos quais os campos de produção cultural manifestam sua distância em relação a esses universos e sobre os quais repousa o modo de valorização das obras. (tradução livre) 
conhecer todos os instrumentos naquele tempo”. (Depoimento de Francisco Mignone para o MIS-RJ, 1968 apud EGG, 2010: 24).

Outras figuras do cenário musical, como Souza Lima, cuja educação também começou em casa, relata a mesma experiência prática, no início de carreira, quando teve de se sustentar tocando em vários cinemas e no Hotel de la Plage no Guarujá. Passou-se o mesmo com Armando Braga e Villa-Lobos (no Rio de Janeiro). Todos estes tiveram de enfrentar as adversidades da precariedade das condições de profissionalização do músico, especialmente na área de criação musical múltiplos eram os casos de enriquecimento de editoras especializadas em música; leis de direitos autorais datam de 1928, mas nem sempre eram observadas.

No entanto, os músicos citados tinham algumas vantagens entre seus concorrentes: o tipo de formação musical advinda de familiares músicos (em geral imigrantes italianos), que costumava não se limitar ao estudo de piano típico das moças da elite, proporcionando-lhes, em realidade, contato com diversos instrumentos e repertórios. A isso, soma-se a falta de recursos materiais por não serem de famílias da elite econômica. A necessidade de ajudar no orçamento doméstico tocando nos meios de divertimento popular, onde eram obrigados a aprender na prática a improvisar, arranjar, dirigir conjuntos, adquirir rapidez de leitura de partituras e tocar de "ouvido" um amplo repertório - que abrangia tanto os maxixes, tangos e valsinhas apreciados pelas classes médias ou baixas, quanto as operetas do gosto dos abonados - converteu-se em mais uma vantagem.

Esta educação musical prática e informal, embora riquíssima e relevante para a compreensão da escolha da principal atividade musical, assim como dos percursos estéticos e técnicos dos compositores em suas primeiras peças, é apagada por eles e por seus biógrafos, que preferem atribuir a opção pelos trilhos da composição ao "dom" inato para a criação musical. Ao elegerem o início da educação musical "séria" a partir de passagens pelas instituições de ensino de música? como marco da determinação "formal" da carreira, pecam em debitar a tais instituições um protagonismo que não tiveram, porquanto desempenharam papéis coadjuvantes na escolha do métier de criação, servindo muito mais à aprendizagem da técnica dos instrumentos (nem isso, no caso de Guarnieri) e/ou a uma rede de contatos para auferir colocações profissionais; ou ao autodidatismo, nem sempre tão solitário, pois orientado por professores particulares (formais ou “informais") e os diversos círculos frequentados pelos músicos. No caso de Guarnieri, tais narrativas mitificadoras atribuem sua formação única e exclusivamente a mestres, responsáveis pelo ensino sistemático de regras e procedimentos para a criação de "música séria" e pelo norte estético, descartando tudo que teria sido retido das movimentações no meio da música popular urbana de divertimento. Só a partir das décadas de 1950 e 1960 essa movimentação seria ressignificada ante a

7 Em São Paulo, o Conservatório Dramático e Musical; no Rio de Janeiro o Instituto Nacional de Música 
aceitação de materiais provenientes da música popular urbana pela crítica, e os compositores a um só tempo deixam de se envergonhar do contato com a música de divertimento dos salões e se regozijam pela oportunidade de terem tomado contato com este "material bruto" na juventude, processado com destreza pelo burilamento formal de criação. A ressignificação, no entanto, não alterou a exclusão das primeiras "pecinhas" do catálogo de obras legítimas de nenhum dos compositores do nacionalismo folclorista, que lançavam mão de pseudônimos para assiná-las. Mignone talvez seja mais aberto ao trato de seu legado ilegítimo, à medida em que enxerga carinhosamente, com ares nostálgicos, suas incursões como "Chico Bororó” pela música popular, em comparação a Guarnieri, cujas obras sinfônicas conferiram a este maior prestígio, levando-o a se diferenciar mais enfaticamente do polo popular do campo na década de 1950. Como Guarnieri começa a carreira de compositor erudito já na década de 1930, pela observação do descrédito à obra popular dos mais velhos, escolhe manter suas peças de juventude, a "obra de difusão interdita", fora de circulação. Tal parte de sua produção, proibida em testamento de ser executada, publicada ou divulgada, está guardada em seu acervo no IEB-USP, sob difíceis condições de ser sistematicamente examinada por pesquisadores (os documentos só podem ser observados, sem que se possa registrar anotações em cadernos, ou aparelhos eletrônicos).

Deste modo, a versatilidade que foram obrigados a cultivar nesse primeiro momento de suas formações seria de grande proveito ao domínio das características esperadas de um compositor. Guarnieri, em sua obra, visitou todas as formas consagradas, da fuga ao ballet, passando pelo prelúdio, variação, sonata, concerto e prelúdio; da canção à ópera, passando pelo madrigal, cantata e missa. O catálogo de Guarnieri, grande e variado, apresenta um perfil que acompanha as múltiplas atividades exercidas, bem como as preferências pessoais. Amante da literatura, escreveu canções para várias formações; regente de coro, no início da carreira, tem obras a capella; maestro de grupos sinfônicos, tem sinfonias e concertos para instrumentos solistas; bom pianista, tem obra vasta e cultuada para teclado; diretor artístico de um grupo de cordas, produziu atendendo às características desse grupo, também. Além da prática em reger e fazer arranjos, é digno de nota o favorecimento à criação musical através da familiaridade de Mignone e Guarnieri com o piano, instrumento típico de estudos de harmonia e contraponto, também facilitador da "visualização" de peças orquestrais pela possibilidade de sintetizá-las em reduções (cf. EGG, 2010). Aliás, não é de se estranhar, ao examinar o catálogo de obras, o fato das primeiras peças para orquestra de Guarnieri serem, na verdade, transcrições de peças originalmente compostas para piano, posteriormente orquestradas. O jovem se sentia desconfortável em compor diretamente para grandes conjuntos, insegurança progressivamente sanada ao longo dos anos em que pôde trabalhar como regente à frente das execuções de sua obra. Além das características relacionadas ao piano, há a facilidade de 
produzir melodias e trabalhá-las. Neste sentido, a qualidade atribuída a alguns deles, por parte da crítica que resgatava a legitimidade da tradição da música popular urbana nos anos 1950 e 1960, de desprendimento em relação a rigidez dos procedimentos técnicos clássicos em favor da espontaneidade ao parecer "improvisar" peças, possivelmente advém da capacidade de improvisar aprendida nos salões e cinemas. Ademais, é provável a constituição de uma memória sonora, de padrões melódicos e rítmicos, amparadas no repertório popular urbano (diferente do material modal) e fixada daqueles tempos nos exercícios de improviso que os auxiliavam a compor.

Ate aqui se pode dizer, em resumo, que dentre os elementos fundamentais deste período inicial de suas trajetórias, ao qual chamamos de formação, destaca-se a luta para contornar um sistema parcamente institucionalizado de educação musical, muito voltada ao aprendizado dos instrumentos e pouco à composição. Portanto, é de se questionar os motivos que teriam levado Guarnieri e Mignone a se tornarem compositores em tempos de demanda mais alta por intérpretes do que por compositores. Em parte, a escolha do investimento na carreira de compositor é facilitada pela "versatilidade", mas só se pode compreendê-la de fato a partir do ingresso de Guarnieri e Mignone nos círculos da alta sociedade, no papel um tanto subalterno que desempenhariam nessas rodas se comparados aos pianistas filhos das próprias famílias abastadas que poderiam lhes franquear acesso aos espaços e oportunidades que controlavam. Ou seja, a desvantagem "de origem" frente a competição com os filhos da elite para a carreira de intérprete de música erudita nesses espaços concorreu para que os dois jovens músicos filhos de imigrantes se tornassem disponíveis para buscar outros caminhos possíveis e projetos estéticos a fim de realizar suas pretensões de prestígio. Prestígio que, como vimos na relação de Guarnieri com os pais, entrelaçava consagração artística, profissionalização do ofício e aspirações de ascensão social. Vejamos a inserção dos músicos nos ambientes de extração aristocrática.

Os musicistas do polo aristocrático, como Souza Lima, tomam um atalho ativando uma verdadeira rede de contatos na qual já estavam inseridos para constituir suas carreiras. Em seu livro de memórias, o pianista começa a elaboração de sua autoimagem a um só tempo destacando o envolvimento com a música e fazendo uma extensa enumeração dos vínculos com a elite dirigente ou ilustres personagens da época, a qual denomina "Minha gente". Demora-se em elencar os parentes ilustres, seus nomes completos, ocupações, filiações, feitos notáveis, cumulando-os de elogios e deferências:

"Meu pai era filho de um industrial português, Souza Lima, que se instalou na cidade, casando-se com uma moça alemã, ou filha de alemães (não estou bem certo), de nome Gertrudes Krauter, de Hamburgo. Seu filho, portanto meu pai, José Augusto, foi casado com Luiza de Azevedo Marques, minha mãe, que era um dos 
dezesseis filhos de Joaquim Roberto de Azevedo Marques. Dessa união nasceram sete filhos: Oscar, José Augusto, Luiz, Antônio, Pedro, João [o autor] e Maria Augusta, que ficou com o apelido de Menina até hoje. Todos esses irmãos estudaram música. A irmã Maria Augusta chegou a adiantar-se bem no piano. Tornou-se uma segunda mãe para mim, incentivando-me, auxiliando-me em toda a minha vida artística. Foi casada com Francisco Martins Teixeira - que desfrutava de alto cargo na Prefeitura (... ) O irmão José Augusto dedicou-se com total tenacidade ao estudo do piano (...) Joaquim Roberto de Azevedo Marques, meu avô materno, foi o fundador do tradicional jornal 'O Correio Paulistano' - de gloriosa memória - folha diária que viveu por mais de cem anos. Possuo e conservo com todo o desvelo o primeiro número deste jornal. Minha mãe (...) contava detalhes interessantes com referência à fatura daquele matutino (...).

Foram meus padrinhos de batismo: D. Virgilina de Souza, senhora distintíssima, fundadora da 'Revista Feminina', que existe até hoje, e o Dr. Cláudio de Souza, ilustre médico, que criou o conhecido medicamento Gelol, muito procurado ainda. O Dr. Cláudio Souza foi também deputado e homem de letras (...) Ainda descendente da família Azevedo Marques foi o deputado, lente da Faculdade de Direito do Largo de São Francisco, Ministro do Exterior no Governo do Dr. Epitácio Pessoa , o Dr. José Manuel de Azevedo Marques, figura de escol, que gozava do título de 'homem mais bem educado de sua época'. Outros tantos membros da família, advogados, militares, tiveram posição de relevo na nossa sociedade". (SOUZA LIMA, 1982, 16-17)

A caracterização de "primo pobre" que Miceli $^{8}$ cria para classificar as origens sociais de parte dos escritores modernistas também pode ser empregada para descrever as condições em que se deram a carreira de pianista de Souza Lima. Seu pai realizou um casamento que lhe favoreceu, na medida em que pode contar com as conexões do sogro em seu percurso profissional. Contudo, não eram abastados, moravam numa casa modesta da Rua Tabatinguera, próxima à Sé. Ainda moço perdeu o pai, o que trouxe a um só tempo dificuldades financeiras e a centralidade da figura do irmão mais velho, um dos primeiros homens a seguir carreira de pianista na cidade, segundo Souza Lima, para o núcleo de suas referências e horizontes de possibilidade. No entanto, como qualquer outro dos jovens músicos, precisou buscar sustento nos já mencionados espaços de divertimento da cidade, mas com a vantagem dos contatos para ingressar nos mais “nobres” deles, logo de saída.

As limitações impostas pelos rendimentos modestos e o anonimato melhoravam consideravelmente quando os músicos eram convidados a tocar em salões de mecenas da oligarquia paulista. Os cinemas, casas de espetáculos, hotéis de luxo, lojas de música e cafés nos quais

8 Ver MICELI, 2001: 104-106 
trabalhavam, faziam as vezes de portas de entrada aos salões, pois davam-lhes possibilidade de circular em ambientes desse segmento social, por indicação de colegas já integrados, tão distinto da proveniência de classe média. Freitas Valle talvez tenha sido dos mais significativos mecenas da música, junto com Olívia Guedes Penteado, por conta do envolvimento à frente da Comissão Fiscal do Pensionato Artístico do Estado de São Paulo, o qual cumpriu importante papel de alternativa real de formação musical, concomitante à atribuição de prestígio ao compositor que fosse agraciado. Em troca, Freitas Valle podia contar com a garantia de ter entretenimento sofisticado e compassado com o que havia de requintado em arte na Europa, angariando para sua figura os louros dos préstimos às artes, modernas ou não - quando não conseguia baixar os custos de transações de investimentos privados com isto, no caso da relação com os artistas das belas-artes.

Da interdependência estabelecida entre Freitas Valle e alguns compositores entre meados de 1910 até os anos 30, destaca-se a experiência do pianista Souza Lima, registrada em um dos capítulos de seu livro de memórias. Souza Lima conta que foi introduzido ao convívio da Villa Kyrial - residência do senador estadual Freitas Valle - por um dos amigos das reuniões da Casa Sotero. O mesmo local onde também foi habitué o jovem Francisco Mignone. Em seu livro de memórias, Souza Lima começa por apresentar o anfitrião com um entusiamo laudatório sugestivo da simpatia que nutria por ele:

“(...) 'Vila Kyrial', mansão de propriedade do Dr. José de Freitas Valle, advogado, político, que ocupou altíssimos cargos no nosso governo. Este homem, de uma cultura excepcional, além de desempenhar com grande brilho e competência as atividades na vida pública de nossa cidade, era um autêntico artista: poeta, escritor, músico, perfumista, conhecedor perfeito de vinhos (possuidor de uma riquíssima adega) e organizador de lindíssimas recepções quando da visita de importantes personalidades a São Paulo. Sua Vila Kyrial se tornou célebre e única por ter sido o centro mais famoso de artistas" (SOUZA LIMA, Op. Cit.,44)

Em seguida, reconta o feitio de confraria que assumiam as reuniões na Villa Kyrial, capitaneadas pelo eminente político:

"Para fazer-se uma ideia do quanto nosso anfitrião prezava os artistas e cultivava o seu convívio, basta dizer que em todos os dias da semana, sem exceção, reunia um grupo para jantar ao seu lado. Assim, nas segundas-feiras recebia pintores, nas terças-feiras escultores, nas quartas-feiras músicos (aos quais chamava: o 'Pessoal da Lira'. Nesse grupo estavam João Gomes Junior, Carlos Pagliuchi, Osório César, eu, os cantores Ernesto de Marco e Santino Giannattasio), nas quintas-feiras poetas, nas sextas-feiras escritores, aos sábados políticos e amigos e aos domingos, em almoços magistrais, realizados no grande terraço de sua bela vivenda, todos os 
que estiveram durante a semana, em quantidade fácil de se imaginar. Nesses domingos passávamos o dia. Depois do lauto almoço, passeávamos no parque que rodeava a casa, divertindo-nos, completamente à vontade até a tarde, quando então, já à noitinha, éramos reunidos na 'Galeria', grande salão onde se apreciava a imensa coleção de valiosíssimos quadros (para os quais havia iluminação própria e adequada), esculturas e objetos de arte. Ali tínhamos, então, alguns momentos de cultura, quando se exibiam músicos, poetas, declamadoras, etc. Nessas tardes tinha-se oportunidade de ouvir o que havia de melhor; por vezes, até obras em primeira audição, leituras de obras literárias que iam ser lançadas, pequenas palestras sobre os assuntos do momento (...)” (idem: ibidem),

Além de se lembrar dos escritores, artistas e políticos recebidos, sua narrativa memorialista nos fornece pistas sobre o tipo de relação estabelecida com cada uma das "categorias" de visitantes, transpostas da representação que essa fração das classes dirigentes fazia das artes e letras, separando as áreas de acordo com interesses distintos - de aquisição e negociação de obras, com os pintores e escultores acadêmicos, no início da semana; de puro deleite e divertimento, com os pianistas e compositores de operetas (Gomes e Pagliuchi), da paixão "desinteressada" pela poesia simbolista às quintas e, possivelmente, sextas. A tônica da relação de Freitas Valle com a música pode ser apreendida nas entrelinhas das anedotas narradas pelo pianista; nesse sentido ganha relevo a intimidade estabelecida com alguns dos músicos, especialmente aqueles oriundos do polo da imigração, ou dos filhos da elite em declínio no caso de Souza Lima, intérpretes do repertório tradicional que lhes era requisitado, ou compositores atendendo ao gosto do senador, enquanto outros ilustres frequentadores não são mencionados:

“Entre os móveis havia uma cadeira especial, uma espécie de trono, no qual só podia sentar-se o nosso anfitrião, que dali dirigia o desenvolver da noitada. Não preciso dizer que havia, além dos móveis, um magnífico piano de meia cauda 'Bechstein'. Por brincadeira, um dos nossos, que fazia parte do 'Pessoal da Lira', fingindo-se distraído, sentava-se na tal poltrona, sendo imediatamente admoestado e expulso com energia por somente aquele que tinha esse direito. O autor dessa façanha não era outro senão Carlos Pagliuchi, possuidor de gênio muito folgazão, $e$ que nos divertia deveras com suas brincadeiras.. Alguns dos componentes do 'Pessoal da Lira' tinham apelidos. Assim, Carlos Pagliuchi, que naquele tempo escrevia muitos tangos que alcançavam muita popularidade, era chamado por 'Tanguqui', o violinista Osório Cesar, que tinha seu cartão de visita com o seu nome escrito 'Caesar' era chamado de 'Caesar'; eu, que escrevia um pouco de música popular com o pseudônimo de 'Xon-xon', era chamado por 'Yan de Botucatu', e isso se explica pelo fato de que numa certa viagem que o Dr. Freitas Valle fez àquela cidade 
para uma convenção política, levando-me em sua companhia, ficamos hospedados, suntuosamente, no Palácio do Bispo. Naqueles poucos dias tive a oportunidade de tocar para algumas pessoas, alcançando bastante sucesso. Daí aquele apelido. Com grande satisfação declaro que o 'Pessoal da Lira' era o grupo que mais gozava da camaradagem do nosso chefe e amigo" (idem: 46).

Se o "Pessoal da Lira" era o que mais gozava da camaradagem, ou não, é questão secundária, embora se saiba que Freitas Valle cultivava, com grande apreço, a poesia simbolista, além das atividades da Sociedade de Cultura Artística, da qual tomava parte, privilegiarem muito mais a literatura e a pintura ${ }^{9}$. O que de fato havia era uma espécie de hierarquia entre os convidados para distinguir os mais próximos, compreendidos num "círculo" de confiança - ao que parece, de aprovação ou adesão aos padrões sociais de gosto e consumo de arte empreendidos ali - dos demais. Sobre a divisão dos convidados, Souza Lima afirma:

"A Vila Kyrial, que possuía um enorme número de frequentadores amigos, era uma espécie de 'Ordem Cavaleiresca', e todos os comensais dos domingos tinham um título, uns sendo 'Cavaleiros', outros menos graduados, 'Aspirantes'. Todos ostentavam na lapela o distintivo de seus graus. O Chefe Supremo, Dr, Freitas Valle, tinha como seu heraldo, o professor Félix Otero [músico]; a língua oficial nas reuniões era o espanhol e cada vez que o Chefe precisava fazer uma comunicação, levantava-se o heraldo e dizia com voz pomposa: 'Habla nuestro jefe y señor', e ao término de sua comunicação, dizia novamente o heraldo: 'Y que se lo tengan por entendidos'” (idem: 47)

Nota-se que a assimetria em favor do anfitrião era atualizada em certos rituais por ele controlados, mesmo entre os mais próximos e entusiastas dos protocolos e “jogos" de consumo requintado, inscritos no horizonte de valores e fruição de bens artísticos. A contrapartida da relação de dependência mútua, no caso dos músicos, eram as grandes oportunidades de viabilização de carreiras num contexto de poucas opções institucionais, que na verdade eram controladas pelos mecenas que as haviam criado. Entre elas, o ingresso em outros salões por recomendação, concertos próprios e apresentações de repertório pela Sociedade de Cultura Artística, bem como as conhecidas bolsas de viagem para a Europa via Pensionato Artístico. Para conquistá-las era preciso galgar posições na escala dos amigos da Vila Kyrial, atendendo a condições que iam da participação nos eventos dos espaços do senador até servir aos interesses artísticos do mesmo a partir do próprio métier, musicando poemas, compondo operetas sobre libretos indicados, criando hinos:

9 Ao longo dos anos 10, a Sociedade realizou diversas atividades: 34 conferências, 74 concertos, 7 espetáculos com declamação de poesia, 1 ópera, 1 balé e uma apresentação teatral. Entre tais eventos, as conferências teriam sido a principal motivação de seus fundadores para organizar a instituição em 1912. 23 delas tinham por tema a literatura, enquanto à música foi dedicada uma única conferência. (cf. BINDER, 2013:55). 
"Freitas Valle dotou sua Vila de um hino de sua lavra, não só na música como na letra e sempre com aquela intenção de estimular os seus amigos músicos, fez questão que os compositores escrevessem uma paráfrase sobre o hino. Assim, depois de pouco tempo, apareceram trabalhos do professor Cantù, de Mignone, de João Gomes Jr., todos para piano. Apenas o meu foi escrito para piano a quatro mãos. Todas essas composições apresentaram interesse de concepção, muito bem elaboradas e escritas com entusiasmo pelos seus autores; alguns até incluíram em seu desenvolvimento o tema principal em forma de Fuga. Muitas composições de valor surgiram naquela Vila de Arte, principalmente em obras para canto e piano, que eram escritas sobre versos, em francês, de Jacques D'Avray, pseudônimo de Freitas Valle (professor e profundo conhecedor da língua). Era professor dessa língua no Ginásio do Estado (...) De Freitas Valle são de grande valor os 'Trajipoèmes', obras literárias e filosóficas (...). Alguns foram postos em música por Alberto Nepomuceno, João Gomes Jr. e Carlos Pagliuchi. Este teve o seu trabalho apresentado em público pelo famoso baixo francês Marcel Journet, que o cantou com acompanhamento de orquestra em concerto no Teatro Municipal. Como disse acima, inúmeras poesias foram trabalhadas musicalmente por vários compositores, enriquecendo assim o repertório de canto e piano. Tive a felicidade de também musicar algumas de suas poesias, entre as quais: 'Amour Avide', (...) e 'La belle aux fleurs' (...). Esses dois trabalhos desencadearam definitivamente o meu futuro e a realização de minha carreira musical. Numa das magníficas recepções na vivenda de Freitas Valle, quando foi recebido e homenageado o grande músico francês Xavier Leroux, este ouviu essas duas composições cantadas pelo tenor Santino Giannattasio. Foram acompanhadas por mim e Leroux aplaudiu-as com entusiasmo, tendo admirado suas harmonizações, que achou de muito bom gosto (...). Imediatamente interpelou Freitas Valle, dizendo: 'É preciso mandar este jovem para Paris, estudar no Conservatório, na minha classe de composição, sem perda de tempo'. Daí resultou a atribuição a mim de uma bolsa de estudos para a Europa. (...) Continuamente as recepções proporcionavam encontros dos mais interessantes e proveitosos. A produção de novas obras era uma constante entre os compositores; as audições continuavam apresentando os artistas da casa e revelando outros, às vezes de passagem por São Paulo (...)” (idem: 47-49).

Conforme descrito, embora não haja como confirmar a história do convite informal de Leroux, foi nesta convivência que surgiu a iniciativa de enviar Souza Lima à capital francesa, em 1919, para aperfeiçoar os estudos de piano com Isidor Philipp (por recomendação de Chiaffarelli e Guiomar Novaes) e Marguerite Long, no Conservatório de Paris. A bolsa do Pensionato Artístico de 
São Paulo era uma decisão praticamente pessoal de Freitas Valle, que presidia a comissão numa época em que não havia qualquer procedimento público de seleção dos bolsistas. Muitos foram os músicos agraciados, proporcionalmente mais pianistas e cantores e alguns poucos da composição (caso de Mignone e Villa-Lobos); todos frequentadores da Vila e, na época que foram, um tanto hesitantes sobre os rumos modernos que as artes tomavam - novamente a exceção de Villa-Lobos, que destoava do perfil social de origem tradicional dos outros. Neste ponto os músicos se distanciam dos artistas modernistas das belas-artes, pois apesar de terem participado da Semana de 22 e frequentarem espaços comuns aos intelectuais e artistas modernistas, não se entusiasmaram tanto com a parte mais moderna do repertório que lá interpretaram por indicação dos organizadores. Suas preferências estéticas e repertórios estavam muito mais identificados aos padrões de gosto, de um lado, das frações mais tradicionais da elite, donde provinham, e de outro, das instituições estrangeiras de formação que frequentaram.

Essa reserva, que chegou a ser abertamente colocada em artigos de jornal e livros, partiu dos pianistas. Guiomar Novaes, Frutuoso Vianna e Antonietta Rudge se pronunciaram após os concertos no Teatro Muncipal. A participação de Vianna, pianista mineiro que fez carreira no Rio de Janeiro, deveu-se unicamente à proximidade com Villa-Lobos, que lhe fez o convite, sem que tivesse preocupações com as ideias modernistas: "Participei da Semana apenas como intérprete, em função da amizade de Villa-Lobos, nada mais” (VIANNA in CASTRO, 2003:25). Sobre a postura de Frutuoso Vianna e Guiomar Novaes, um biógrafo daquele afirma:

“Acabava o seu número, Frutuoso ia para dentro. Não estava interessado senão em fazer música; não estava interessado em abranger toda a figuração daquela coisa que movimentou demais o ambiente. Sabia que eles estavam recebendo vaias $e$ tudo e achava que em alguns casos havia até razão. Houve um grande protesto da Guiomar Novaes contra o que se estava fazendo na Semana e Vianna protestaria também, segundo afirmou mais tarde. Satie fez uma peça debicando Chopin e Ernani Braga tocou-a em plena Semana de Arte Moderna. 'No fundo tenho certeza que o próprio Ernani não estava gostando daquilo", diria depois, "foram as circunstâncias que o levaram a tocar aquilo, assim como poderiam levar-me também'; pois Chopin, para Vianna, 'não é um autor que a gente apenas admira; é um autor que a gente ama!'” (idem:27).

Anos mais tarde, já na década de 60, ajustaria o discurso sobre o balanço da Semana, enquanto iniciativa louvável e corajosa, empregando o jogo de termos "antigo vs moderno" significativo da fatura modernista, embora mantivesse a reserva em reconhecer o valor artístico das produções modernas em declarações como estas: "Achei excelente para o nosso meio, como uma chibatada na rotina” e “(...) Oswald de Andrade, Sérgio Milliet... esses é que foram vaiados e os 
motivos não foram suas obras; foram vaiados por menosprezar a parte antiga da arte e abraçarem ali, a priori, sem razão plausível, as coisas, só por serem modernas, embora não fossem realmente arte” (idem: 28). As relações de Vianna com as principais figuras do modernismo paulista raramente se converteram em realizações de seu projeto artístico. Para isto, contou de início com a família para financiar parte de sua viagem à Europa e com os contatos getulistas do meio carioca, sendo Villa-Lobos seu propulsor. Não à toa, pouco se serviu das expressões nobilitadoras da doxa modernista de "artista nacional", exaustivamente usadas na construção da consagração e do legado de seus colegas paulistas, ou cariocas associados ao modernismo; nem mesmo depois da integração de seus líderes ao Estado Novo de Getúlio. Frutuoso Lima-Vianna nasceu em Itajubá, Mina Gerais, em 1896, segundo filho de uma família com recursos da região; seu avô materno era imigrante português jurista e jornalista; seu pai, Miguel Arcanjo de Souza Vianna era magistrado, industrial e bacharel em Direito, formado no Largo São Francisco, na última turma da Monarquia (1889) e seu irmão mais velho, Luiz, tornou-se engenheiro químico em Ohio, EUA, através de uma bolsa do Estado de Minas. Sua família era entusiasta de música, amadores até então: o pai era tenor (chegou a estudar com o compositor de óperas João Gomes de Araújo), tocava piano e gostava de compor valsas e polcas; a mãe tocava piano e cantava em reuniões da sociedade, assim como a irmã; o irmão mais velho também cantava e tocava piano; entre seus tios havia compositores relativamente conhecidos e um pintor formado na Escola Nacional de Belas Artes. Iniciou-se aos 8 anos com professores franceses estabelecidos em Itajubá, até ir completar os estudos no Rio de Janeiro, com Henrique Oswald em 1913, um pouco a contragosto do pai advogado, preocupado com os parcos meios de subsistência dessa escolha (cf. CASTRO, 2003:11-20). Estabeleceu-se no Rio de Janeiro, onde travou contato com Villa-Lobos, como vimos.

A mesma desidentificação com as vias de legitimação artística providas pela experiência do modernismo se deu com outros agentes do polo aristocrático, afinal não se conhece Guiomar Noaves, Magda Tagliaferro e Antonieta Rudge como valorosas intérpretes da "música nacionalista". Ao contrário, fizeram fama antes de 22 enquanto exímias "porta-vozes" do repertório francês, alcançando prestígio na Europa. Já o grande protesto da pianista paulista Guiomar Novaes, a que o biógrafo de Vianna se refere, é o depoimento publicado no jornal O Estado de São Paulo, em que se justifica num tom de desculpas:

“Em virtude do caráter bastante exclusivista e intolerante que assumiu a primeira festa de arte moderna, realizada na noite de 13 do corrente [o artigo é publicado no dia 15 de fevereiro, dois dias depois da apresentação], no Teatro Municipal, em relação às demais escolas de música, das quais sou intérprete e admiradora, não posso deixar de declarar aqui o meu desacordo com esse modo de pensar. Senti-me since- 
ramente contristada com a pública exibição de peças satíricas à música de Chopin. Admiro e respeito todas as grandes manifestações de arte, independentemente das escolas a que elas se filiem, e foi de acordo com esse meu modo de pensar que, acedendo ao convite que me foi feito, tomei parte num dos festivais de Arte Moderna” (NOVAES in idem: ibidem)

É provável que a mea-culpa tenha sido motivada pela notoriedade que ganhou como intérprete de Chopin e as oportunidades de projeção internacional dela advindas, o que reforçaria a tese de que teria sido convidada a tocar na Semana menos por identificação estética e política com o movimento, e mais em função do brilho do reconhecimento internacional de sua presença.

Nos casos das mulheres, a questão de gênero parece se sobressair à da origem social como condicionante de escolhas e opções de percurso e há muitos elementos em comum aos itinerários que evidenciam essa relação ${ }^{10}$. Se considerarmos artistas, sem distinção entre cariocas, mineiras e paulistas, nem em relação à descendência estrangeira, como Novaes, Rudge, Magdalena Tagliafferro, Paulina D'Ambrosio, Vera Janacópulos e Bidu Sayão, veremos praticamente as mesmas portas abertas e portas fechadas atinentes à carreira que podiam seguir. Muito embora algumas delas realizassem atividades de composição e regência, só conseguiram enveredar com reconhecimento dos pares pelas vias da interpretação - o que não era de pouco prestígio; pelo contrário, na época, essas instrumentistas eram famosas e seus nomes conferiam legitimidade a eventos, como vimos no caso de Novaes, e a jovens compositores. Praticamente todas foram cedo à Europa para completar a formação iniciada por incentivo dos pais e construíram reputação lá - as que tiveram apoio da família.

Paulina D'Ambrosio iniciou estudos em São Paulo e logo foi para a Europa concluir no Conservatório de Bruxelas a formação de violinista ${ }^{11}$, só retornando ao Brasil por ter sido impedida pela família de seguir no exterior com sua carreira. Prosseguiu no Rio de Janeiro e se tornou spalla da Orquestra Sinfônica. Já Janacópulos e Sayão após estudarem na França, permaneceram no exterior, respectivamente na Europa e nos EUA, estabelecendo sólida reputação como cantoras de câmara, no primeiro caso, e de ópera, no segundo. Vera, nascida em Petrópolis, em 1892, tinha origem social mista, mas era quase estrangeira. Seu pai era grego e sua mãe tinha por irmão um Ministro do governo Epitácio Pessoa. Um pouco à revelia da família, foi morar em Paris aos 4 anos

10 Os dados de cada itinerário foram extraídos do estudo de Dalila Vasconcellos Carvalho, anteriormente citado, e cotejados com os poucos materiais a que tive acesso sobre essas artistas. Como tais são escassos, reproduzo quase que integralmente as informações dessa fonte, mais concentradas no capítulo "Vocação musical: conexões de gênero e classe social em três gerações de músicos" (pp. 23-84)

11 Apesar de ter sido uma das poucas musicistas a se engajar no modernismo e ter feito "escola" no ensino de violino na Escola de Música do Rio de Janeiro, não há biografias, nem boas fontes de informação sobre D'Ambrosio. Não há como saber ao certo como financiou seus estudos em terras estrangeiras. De sua procedência, sabe-se que era filha de imigrantes. Provavelmente eram de extração social média, mas não há como se ter certeza. 
com a irmã mais velha, que se formaria escultora. Estudou violino com Enescu e canto, área pela qual foi convidada mais tarde à cátedra no Conservatório de Paris - o que recusou face a obrigação de naturalizar-se francesa. Apresentou-se no Brasil poucas vezes em comparação com suas tantas tourneés na Europa. Sayão, por sua vez, nasceu no Rio de Janeiro, em 1902. Perdeu o pai muito cedo, fato que se diz ter impedido sua escolha de virar atriz (por influência do tio, o teatrólogo Alberto Costa), visto que, aos olhos da mãe, a profissão era "moralmente" arriscada para uma mulher sem o pai. Começou a estudar canto na adolescência, fez sua estreia no Teatro Municipal aos 18 anos e, quatro anos depois, rumou para a Europa para completar os estudos e fazer carreira. Bidu, Vera e Paulina foram as principais intérpretes das obras de Villa-Lobos e ajudaram-no nos primeiros anos de sua carreira com a legitimidade de seus nomes já conhecidos. Em meio a escassez de informações e trabalhos, o levantamento de informações sobre a família, as ocupações dos pais e irmãos, bem como o envolvimento destes nas atividades musicais limita o relevo sociológico que pretendemos dar a essas personagens. Em compensação, há mais fontes de dados sobre as trajetórias das pianistas célebres.

As três pianistas mencionadas, Novaes, Tagliafferro e Rudge, assemelham-se logo nos primeiros passos, tomando aulas de piano por volta dos 5 anos de idade e se apresentando em público aos 10, aproximadamente. Criadas em ambientes tradicionais, o incentivo aos estudos musicais vinha da família, para que se educassem aos moldes dos padrões femininos da elite da época. Guiomar nasceu em 1894, em São João da Boa Vista, interior de São Paulo, sendo a $17^{\mathrm{a}}$ filha de um total de 19 irmãos. Seu pai era negociante de café e major do Exército, enquanto sua mãe, Anna, havia aspirado a uma carreira de pianista e incentivava as filhas mais velhas a realizarem o que não havia logrado. Graças ao apadrinhamento da jovem por Alda Silva Prado, vai a São Paulo tomar lições de piano com Chiaffarelli, que a prepara para o ingresso no Conservatório - em 1919, aos 15 anos, vai à Paris por meio do Pensionato Artístico. Sua carreira, repleta de concertos e prêmios importantes, pode ser longa e duradoura por conta do apoio do marido, que se engajou na vida artística de Novaes como empresário, cuidando das finanças e dos filhos. Magda, de Petrópolis, nasceu em 1893 de pais imigrantes franceses abastados e assim como a mãe de Guiomar, seu pai fora um pianista frustrado. Segundo suas memórias, ainda que seu avô tenha interferido nos projetos musicais de seu pai, obrigando-o a se bacharelar engenheiro e exercer a profissão, muitos anos mais tarde se tornou professor de música, alternativa à impossibilidade de ser pianista com mais idade. Imbuído da ambição que tivera, cultiva-a num projeto de carreira para a filha, cujo ingresso no famoso Conservatório de Paris constituía uma das principais metas na etapa da formação. Magda ingressa no Conservatório aos 13 anos, ganha o principal prêmio da instituição para pianista aos 14 e, em seguida, sai em tourneé com o compositor Gabriel Fauré pela França. 
Antonietta, por sua vez, nasceu na capital em 1885, de pais bastante abonados de ascendência inglesa; por influência da mãe se iniciou ao piano cedo e precocemente, aos 8 anos, apresentou-se na extinta Sala Levy. Sendo a exceção à regra, não frequentou o Conservatório de Paris; no lugar, foi acompanhada durante toda a sua educação por Chiaffarelli. Continuou se apresentando depois em espaços da elite cefeeira e imigrante, como o Salão Steinway, o Clube Internacional, Clube Germânia e o Teatro Municipal, bem como nos inúmeros concertos que deu pela Sociedade de Cultura Artística (a qual ajudou a fundar e financiar com os recursos da família). Depois de se casar com o primo Charles Miller, também de origem inglesa, organizou apresentações em Londres e em cidades da França e Alemanha. Após ter filhos e enfrentar certa resistência do marido, recusou convites para novos concertos na Europa, até que o divórcio com Miller, em 1920, fez cessar de vez sua bem-sucedida carreira. Isto se deve ao "escândalo" em torno do divórcio, pois ao desmanchar o casamento anterior para viver com o poeta Menotti Del Picchia, figura pública tão conhecida quanto seu ex-marido, foi reprovada pelos círculos em que se movimentava.

As circunscrições a carreiras na área de interpretação de repertório a que as "heranças" familiares conduziam mulheres provenientes de ambientes familiares musicais, e o maior peso do fator do casamento na determinação das condições de possibilidade de seus projetos artísticos enquanto signo da estabilidade da carreira, no caso de Novaes, ou de instabilidade no caso de Rudge são dois pontos característicos das trajetórias femininas. Em contraposição à "especialização" feminina, a "multiplicidade" masculina cultivada na "versatilidade" a qual, como vimos, facultava aos homens outras áreas da música, como a composição e a regência. O casamento, embora também pudesse denotar o mesmo signo de estabilidade, não era tão determinante na viabilização de seus projetos - Guarnieri se casou três vezes, Mignone duas e Souza Lima uma vez, sem que a vida um tanto nômade desses artistas fossem significativamente alteradas por ter de cuidar da família, geralmente tarefa delegada às esposas. No caso dos homens, os casamentos passavam por outros sentidos, como o de formar alianças com famílias tradicionais que lhes auxiliassem em seus caminhos pelas instituições (caso de Souza Lima que se casa em um arranjo com a família Amaral), ou de suporte à carreira, quando se juntavam a mulheres musicistas, ou entusiastas, que participavam ativamente das vidas artísticas dos maridos, o que implicava estabilidade, uma vez que se liberavam das obrigações domésticas para se empenharem em seus planos (como Guarnieri, Mignone e Villa-Lobos), interpretando peças, organizando a obra, acertando detalhes das viagens a trabalho, juntando materiais úteis à construção do legado dos maridos, etc.

Assim como nos itinerários femininos, os homens também dependiam de períodos na Europa, principalmente aqueles que seguiram os caminhos da especialização em um instrumento. Para estes, o significado da viagem era o mesmo. Já com os compositores, este lemento adquiriu 
outros sentidos, entre eles abrir vias de divulgação de obras, além de entrarem em contato com o que havia de mais recente na linguagem musical erudita. Em São Paulo, estavam limitados tanto aos salões e festas da oligarquia, quanto aos horizontes do gosto convencional que seguiam por orientação dos professores italianos trazidos de seu país pelo mecenato oligarca, alocados nos quadros do CDMSP. Assim, os primeiros musicistas paulistas a viajarem, ou seja, aqueles que o fizeram antes da derrocada do Movimento Constitucionalista de 32, e o consequente esmorecer de forças de seus patronos, aproveitaram suas estadias para servir aos padrões estéticos aos quais depois se oporiam ao se juntarem às hostes modernistas.

Como vimos, Souza Lima mudou-se para Paris em 1919, como bolsista, caminho que seria trilhado por Mignone em 1920 rumo a Milão, e por Villa-Lobos rumo a Paris em 1923. Mignone relata em entrevista ao Jornal do Brasil, em 1968 os propósitos de sua viagem:

“(...) Para encurtar, direi que a Comissão do Pensionato Artístico do Governo de São Paulo, chefiada pelo meu protetor, o saudoso senador Freitas Valle, achou que eu devia ser, para o Brasil, o êmulo de Carlos Gomes. E lá fui eu despachado para Milão. Aí escrevi duas óperas e assim cumpria a missão de compor óperas justificando o meu pensionato. Em Milão, quase que às escondidas, estudei de novo harmonia, contraponto e fuga com o velho Vicenzo Ferroni, todo imbuído de Savard, Dubois, Massenet e César Franck. E, creiam, essa foi uma coisa da qual jamais me arrependi. Pois, confesso agora, estava muito cru em fato de música” (MIGNONE in MARIZ, 1997:45).

Camargo Guarnieri, mais novo que os colegas, viaja à Paris somente em 1938, selecionado por meio da concessão do Prêmio de Aperfeiçoamento Artístico, controlado por um outro aparato público, o Conselho de Orientação Artística que foi instalado no lugar do Pensionato Artístico. Já sob maior controle dos modernistas, suas viagens foram estratégicas menos à formação do compositor, apesar da relevância das aulas com Koechlin, e mais pela construção da legitimação de “compositor sinfônico". Da breve estadia em Paris, pode-se dizer por enqunto que expressa o duplo intento de, concomitantemente, instruir-se e se firmar como "compositor".

Entretanto, ainda na década de 20, se a situação de indiferenciação dos meios musicais da época não oferecia a seus agentes um leque de colocações tão diversificadas assim na "estrangeira" cena erudita da cidade para os musicistas desprovidos das credencias da estadia no exterior, confinando-os à "versatilidade" do meio da música urbana, deixava-os igualmente na escassez de opções de ensino formal, sem o qual não adquiririam habilidades que lhes valessem maiores êxitos nos espaços da música erudita, nem no aprendizado do métier. Os jovens compositores, então, 
tiveram de buscar soluções para aprender música e manter o sustento, ao mesmo tempo que almejavam destaque em alguma das áreas musicais, sem precisarem ser "versáteis" na noite da cidade. A carreira de pianista, como vimos, estava reservada aos membros com maior facilidade de acesso ao "combo" formado, de um lado, pelos professores particulares das moças e "primos pobres" ligados às oligarquias, ou aos industriais imigrantes, que os preparavam tecnicamente e, de outro, patronos que lhes enviassem ao Conservatório de Paris, financiando-os com bolsas públicas ou auxílio familiar direto.

Em 1924 e 1927, Guarnieri trava conhecimentos com outros dois professores que viriam a lhe dar aulas de graça, respectivamente Antônio Sá Pereira, professor de piano no Conservatório Dramático formado na Europa (Alemanha e Suiça) e Lamberto Baldi, maestro italiano contratado pela Sociedade Filarmônica de São Paulo - naquela época era típica a contratação de regentes italianos de razoável ou médio prestígio na Europa, ao gosto "cosmopolita" dos frequentadores de ópera criticado por Mário de Andrade. Ao contrário do que se poderia esperar, Baldi era um simpatizante de correntes do modernismo europeu, e incorporou parte do referido repertório na elaboração de programas dos concertos que dirigia, no que foi elogiado por Mário de Andrade nos jornais. O estabelecimento do decisivo vínculo com Baldi não poderia deixar de ser representado nas biografias por meio do enaltecimento do gosto pelas produções modernas, numa espécie de chancelamento modernista ao maestro italiano, diferenciando-o dos "outros" italianos que vinham ao Brasil com as companhias de ópera. Assim, a biógrafa Maria Abreu retrata o encontro, despindo Baldi das eventuais contaminações "europeizantes", para lhe vestir de "estrangeiro moderno" pronto a contribuir com a parte "técnica" da formação de um jovem compositor nacionalista - a Mário de Andrade ficaria confiada a "orientação estética":

"Guarnieri assistiu a um concerto seu e ficou empolgado. A tal ponto que, vencendo sua timidez, foi ao camarim cumprimentá-lo. Vê-lo de perto. No dia seguinte, houve um encontro mais demorado e de resultados definitivos. A conversa em italiano entre o pai de Guarnieri concluiu assim:

- Vou permanecer algum tempo no Brasil, Preciso de um aluno e seu filho de um professor. Vamos ver se serei o professor que ele espera e ele, o discípulo de que necessito.

A partir de então, Guarnieri começou a trabalhar muito seriamente orientado por un vero maestro! Diferentemente daqueles que haviam feito de São Paulo um porto seguro para uma notoriedade fictícia: eram os italianos que vinham com companhias de ópera e opereta (...) Músicos cuja significação em seu país de origem era pouca ou nenhuma, mas que no Brasil se tornavam, sabe-se lá por quê, representantes do prestígio europeu. A esses Mário de Andrade combateu sem dó nem piedade. 
E venceu-os ao impedir que a nacionalidade da arte brasileira se afogasse em águas de tão pouco profundidade Mas com Lamberto Baldi o caso era outro, oposto ao amadorismo arrogante (...) Mário, de imediato, reconheceu nele o verdadeiro músico, excelente diretor de orquestra, enfim, alguém que só poderia contribuir para o enriquecimento do país”. (ABREU in SILVA, 2001:39)

Torna-se uma grande referência para Guarnieri, por lhe ter proporcionado estudos sistemáticos de áreas compreendidas na criação musical, como harmonia, contraponto, fuga, orquestração, etc, durante quase 5 anos. Em depoimento de 1959, Guarnieri afirma:

"Do ponto de vista da técnica de composição, devo a Lamberto Baldi os ensinamentos mais eficazes e que constituem os princípios básicos que ainda hoje adoto.” (GUARNIERI in Op. Cit.,15).

Estes dois professores fornecem a instrumentalização da qual o compositor se muniria a fim de contornar o déficit de condições de formação erudita do campo musical. O deficit de meios de subsistência também é sanado, pois por indicação de Sá Pereira é nomeado, já em 1927, regente da classe de piano e acompanhamento no Conservatório, onde posteriormente, assumiria a turma de composição de Baldi em 1931 e seria por pouco tempo diretor da instituição entre 1960 e 1961.

No entanto, não só os almejados estudos formais de piano e composição definem a importância dos três professores de Guarnieri em São Paulo, somando-se Ernani Braga. Todos se engajaram de alguma forma no projeto modernista e proporcionaram o decisivo acesso do jovem aluno ao movimento cultivado em círculos de sociabilidade estratégicos à viabilização de posições auferidas nas décadas seguintes em órgãos públicos. Muito do direcionamento à composição e orientações dos melhores caminhos a se trilhar para conquistar espaço num campo musical desafiador à carreira vem do convívio com Braga e Sá Pereira - para não mencionar a introdução à estética do nacionalismo folclorista, no que devem ter antecipado o papel cumprido por Mário de Andrade na vida do artista. Pedagogo e pianista que tiveram o auge no varguismo, Sá Pereira e Braga promovem nas rodas cariocas o aluno promissor, inclusive a Luiz Heitor, quando se mudaram para o Rio de Janeiro na década de 1930. Não menos importante no estabelecimento de redes, Lamberto Baldi desperta em Curt Lange o interesse em conhecer o aluno. Veremos mais tarde que, por influência dessas alianças, Guarnieri chamaria a atenção de agentes ligados às políticas de cultura para a América Latina dos Estados Unidos em meados dos anos 1940.

Contudo, para as biógrafas amparadas nas memórias do compositor, o maior responsável pelo acesso do jovem ao círculo modernista, e posteriormente sua posição de destaque, foi Mário de Andrade. Não à toa, evidenciam Abreu e Verhaalen, Guarnieri se refere constantemente a Baldi e Mário como seus dois grandes mestres; o primeiro pela educação clássica e sólida de composição e 
o segundo pela educação cultural e orientações estéticas, seguidas fielmente. Mesmo tardiamente, nos anos de publicação de suas biografias oficiais, o vínculo com Mário de Andrade continuou sendo um importante fator de legitimação de sua fase de formação. Contudo, é de se questionar a efetividade do encaminhamento quase "dirigista" dado pelo intelectual ao compositor - não significando, com essa sugestão, que o papel de orientador estético de Mário possa ser desprezado em sua formação. Só para se ter uma breve ideia do que será mais detidamente tratado no próximo capítulo, os exercícios de fuga, contraponto e harmonia feitos a partir das aulas particulares com Baldi, disponíveis no arquivo do compositor no IEB, evidenciam uma formação "clássica" e convencional, típica dos antigos conservatórios europeus, permeada pelas formas tonais, como o “alegro de sonata", enquanto Mário em seu texto "Ensaio sobre a música brasileira" sugeria a busca por formas mais ligadas à fala e à dança para dar conta do material modal folclórico eleito por ele.

Se Mignone relata a primeira aproximação com o intelectual a partir das aulas que davam no mesmo lugar, o Conservatório, o relato de Guarnieri é fixado por este como um marco em sua vida, um divisor de águas. A versão é mais ou menos esta: por intermédio do amigo e pianista Antônio Munhoz, em março de 1928, Guarnieri foi apresentado à figura central do movimento modernista e executou ao piano algumas peças escritas durante os estudos com Baldi. É relevante lembrar que entre sua obra até 1928, já constavam essas peças de seu catálogo autorizado, afora as relacionadas no que se convencionou chamar de "obras de difusão interdita"; incluem-se entre as autorizadas Dança Brasileira e $1^{a}$ Sonatina (publicada em 1929, dedicada ao líder modernista). Mário gosta do que ouve e ambos passam a se encontrar semanalmente para discutir questões de criação artística, estética, literatura, cultura brasileira, etc. Estes encontros são exaltados pelo compositor em falas tardias, como nesta entrevista de 1976:

“Eu era um sujeito bisonho, mal saído do segundo ano do grupo escolar. Mário não só organizou um plano para meus estudos, onde obras de valor universal estavam presentes, como também colocou sua biblioteca à minha disposição”(Entrevista ao Diário de São Paulo, 4/05/1976 apud ABREU, 2001:40)

Talvez mais do que cumprir papel de mestre num primeiro momento, Mário tenha aproveitado os espaços nas colunas de crítica cultural de que dispunha nos jornais aos quais colaborava para divulgar o trabalho do recém-estabelecido amigo, escrevendo regularmente sobre as qualidades “nacionais” das peças. Ainda na referida entrevista de 1976:

"Nessa altura de minha vida, alguns trabalhos meus haviam sido impressos. Um punhado de críticos surgiu para me atacar. Mário de Andrade, sabedor de tudo, pôs-se a defender-me pelas colunas do Diário Nacional" (entrevista do compositor ao Diário de São Paulo, em 4/05/1976 apud idem). 
A visão de que Mário era uma espécie de mentor que determinava vários dos aspectos musicais presentes nas obras de Guarnieri passa a ser amplamente aceita por outros agentes da crítica musical próximos ou simpáticos a Mário. Eurico Nogueira França, por exemplo, afirma:

“Com seu prestígio de crítico, Mário de Andrade lançou-o, quando Guarnieri compôs a Dança Brasileira, e daí por diante ia pelos jornais amparando o jovem compositor com a imparcialidade de suas observações, restritivas ou elogiosas, mas sempre fecundas, enquanto pessoalmente galvanizava o discípulo em longas discussões que tratava com ele sobre os problemas da criação musical” (Eurico Nogueira França, 1968 apud VERHAALEN, 2001: 25)

Em contraste, observa Egg, tem-se a representação corrente difundida da autossuficiência de Villa-Lobos, tido como autodidata, um aliado de Mário, mas de difícil de ser "influenciado" por este na estética; Villa-Lobos seria um "modernista por si só" aos olhos da crítica. Quanto aos dois compositores mais novos, Mignone e Guarnieri, falava-se largamente em "influência direta", "mentor", "mestre". Mignone é visto por parte da crítica modernista como "italianizado" demais, como se tivesse que ser "convertido" por Mário à cultura brasileira, ao passo que Guarnieri, nascido em meio ao ambiente rural do interior, onde o folclore não tinha sido contaminado pelo "cosmopolitismo" urbano, de saída portaria maior potencial. Com efeito, tomando um fantasioso instante de "eleição do pupilo pelo mestre" como referência da "nova fase" de "compositor erudito profissional”, egresso da fase "(1923-1928)" de pianista de salão, o incremento biográfico e a crítica da época, a um só tempo forjam Guarnieri como herdeiro "mais legítimo" do modernismo e encobre um longo processo de determinação social, isto é, o período de formação em que Guarnieri progressivamente vai se encaminhando para a composição, área que lhe parece mais "rentável" para cavar um lugar próprio no difícil meio musical erudito. É de se imaginar a difícil adaptação ao meio musical paulista, repleto de problemas que deveriam despertar insegurança a um jovem artista, portador de tantos investimentos simbólicos e materiais da família ao seu projeto de ganhar destaque e se profissionalizar num meio incipiente para tal. Transição disfarçada pelo próprio compositor de ponto de inflexão, que pode ser observada, inclusive, na organização de seu catálogo, pois o material de antes de 1928 entrou em interdição, como já tratado. Sobre este material, ao qual não tive acesso por contingências de manutenção e deslocamento do arquivo, outro pesquisador comenta:

"Mesmo submetidas a um olhar superficial, as obras incluídas nessa coleção revelam que a técnica composicional de Guarnieri vinha de modo geral da sua atuação como pianista de música ligeira. As obras são tonais, acordes construídos em forma de tríades ou tétrades sobre graus da escala diatônica, essencialmente os acordes de Tônica, Subdominante e Dominante [o que me sugere cadências simples de desen- 
volvimento] - este último usando às vezes a sétima. Este tipo de construção indica que nas primeiras peças escritas na década de 1920, a harmonia era para

Guarnieri uma construção prática - não vinha do estudo teórico. Construção prática a partir de um repertório simples, de pouca inovação ou elaboração musical, pois complexidades harmônicas de diversos tipos (modulações, cromatismos, acordes alterados) já vinham sendo experimentados há quase um século no repertório de concerto. Outro indicativo é a predominância do compasso ternário simples, derivado da rítmica da valsa, que constituía o principal domínio de um músico de salão em São Paulo. A rítmica desenvolvida nas peças de Guarnieri deste período, em geral tratam o ritmo de forma a enquadrá-lo dentro da pulsação básica, e dos acentos do compasso ternário: não há mudanças de compasso, deslocamentos de acento ou figuras irregulares, como já era usual nas composições que vinham do uso de técnicas mais elaboradas" (EGG, 2010:55).

O caderno de exercícios da época de aluno do maestro italiano, compreendido em sua obra interdita, atesta a iniciação do jovem na educação formal de composição. Das primeiras pecinhas da adolescência às lições mais convencionais, e dessas para uma maior abertura, no decorrer dos quase cinco anos com Baldi, às linguagens e técnicas do modernismo europeu:

"De uma escrita pianística convencional, em que a mão direita toca a melodia principal, e a mão esquerda complementa com acordes formados em tríades, a partir do estudo com Baldi o compositor passa a desenvolver a técnica de combinar linhas melódicas independentes, numa textura mais elaborada, e numa linguagem harmônica que passa a fugir da obviedade de tônicas e dominantes. Da harmonia tonal para o contraponto modal, era uma grande passagem de estilo, que simbolizava o aprendizado das técnicas mais modernas em uso na época, ligadas às vanguardas não-germânicas” (idem: 57).

Quando, em 1931 Baldi é convidado por Curt Lange para trabalhar no SODRE (Serviço Oficial de Difusão Rádio-Elétrica) em Montevidéu, isto é, no cargo de regente da orquestra vinculada, e por lá se instala até falecer em 1979, deixa de dar aulas para Guarnieri. Sabe-se por artigos de jornais uruguaios que Lamberto Baldi é considerado um dos principais operadores da modernização do meio musical do país vizinho e responsável pelo investimento de compassá-la ao que se fazia de novo na Europa (cf. GROSSI, 2002). A menção de Mário de Andrade a Baldi, em sua coluna no Diário de São Paulo, não deixa de ressoar tal atributo "oxigenador" do ambiente musical. Egg afirma:

"Afora Baldi, as únicas experiências tentadas no sentido de modernização da vida musical da capital paulista eram os convites a Villa-Lobos para organizar concertos, ou algum regente estrangeiro como Otorino Respighi, trazido por iniciativa da 
editora Recordi para concertos em 1927”. (idem:56)

Os métodos de ensino de composição do maestro italiano, cujo objetivo, segundo Guarnieri, era despertar no aluno a busca por seu próprio caminho na harmonia e na construção de um estilo particular, era reverenciada por críticos e professores de música dos círculos paulistas do modernismo. Sá Pereira, em artigo de 1929 no Diário de São Paulo, "Mozart Camargo Guarnieri uma esplêndida afirmação da música brasileira", escreve:

“(...) o professor de composição, mesmo muito competente, sendo estrangeiro, pode, sem querer, asfixiar um talento em formação, simplesmente por não compreender $o$ espírito novo do ambiente em que vive, o que oferece novos problemas e exige novas soluções. E é nisso que vejo a grande superioridade do maestro Baldi, que soube submeter o seu aluno a uma severa disciplina de contraponto, sem todavia lhe tiranizar o espírito com o torniquete da idolatria estéril pelas coisas feitas, incitando-o ao contrário a procurar uma solução nova, um estilo pessoal, aproveitando e fortalecendo as tendências nacionalistas já tão pronunciadas do aluno. Foi para Camargo Guarnieri verdadeiramente providencial o fato de se ter o maestro Baldi fixado em São Paulo. Não conheço ninguém que lhe pudesse ter guiado o estudo com a mesma largueza de concepção artística aliada à mais severa disciplina escolar”

Concluindo de forma contundente:

"E penso que sem o encontro providencial com tal maestro, o autor da Sonatina talvez estivesse agora, como amador sem mestre, a compor tanguinhos, ou como pretensioso e mal-guiado, a escrever rapsódias, burlescas e polonesas internacionais” (Transcrição do artigo. In SILVA, 2001:24)

O método de ensino de Baldi parecia consistir em requisitar toda sorte de exercícios de escrita, conjugando a isso o estudo dos instrumentos tradicionais, cobrando do aluno que participasse de apresentações que dirigia na Sociedade Sinfônica. Não nos parece descabido questionar em que medida, em meio a tantas fugas convencionais e contrapontos modais, coisas que geralmente se opõem na linguagem musical, a aprendizagem do métier com Baldi instrumentalizou Guarnieri para o que Sá Pereira chamou de "as tendências nacionalistas já tão pronunciadas do aluno". É provável que o professor, simpático às correntes musicais mais recentes da Europa, tenha disposto ao aluno aquilo que considerou mais cabível dentro das expectativas dos modernistas paulistas - cujas críticas a algumas experiências da vanguarda, ou ao seu uso pelos jovens compositores são conhecidas de artigos e missivas de Mário. Entre exercícios mais tradicionais, no entanto, é possível que Baldi tenha apresentado minimamente ao aluno técnicas de compositores como Schoenberg, Berg e Hindemith, dos quais Guarnieri teria buscado partituras no acervo de Mário. Em que pese tais considerações, talvez melhor seria essignificar o adjetivo "aberto" com 
que se qualificou a pedagogia do maestro para aberto às demandas simbólicas do meio musical no qual, assim como o aluno, circulava - e dependia. Ou seja, demandas de renovação da linguagem musical, mas dentro dos interesses e parâmetros retraduzidos na orientação estética prestada pelos intelectuais aos compositores. Há indícios disso na assimilação um tanto contraditória e "filtrada" de tais métodos por Guarnieri em suas próprias atividades como professor, quando nas décadas seguintes almeja formar uma "escola nacionalista" de composição dando aulas gratuitas para alunos selecionados mediante avaliação de potencial talento. Percebe-se traços do legado de Baldi nos seguintes trechos do depoimento "Meu professor Camargo Guarnieri" prestado por Osvaldo Lacerda para o livro organizado por Flávio Silva:

"Foi assim que, preliminarmente, Guarnieri me submeteu à seguinte prova: harmonizar imediatamente, sem auxílio do piano, uma pequena melodia modal por ele escrita. (...) As variações eram ruins, mas Guarnieri, bondosamente, julgou descobrir em mim algo aproveitável, e me aceitou como aluno”

Ou ainda:

“As primeiras formas estudadas foram o Tema com Variações e a Invenção. (...) A Invenção (...) constitui um meio ideal para libertar o aluno do rigor do contraponto escolástico, e prepará-lo para a composição da fuga. (...) Os temas das invenções, que seus alunos trabalham, são escolhidos pelo próprio Camargo Guarnieri que costuma extraí-los de dois livros: Ensaio sobre a música brasileira de Mário de Andrade, e Melodias registradas por meios não-mecânicos, coletânea de melodias folclóricas brasileiras, publicada pela Discoteca Pública Municipal de São Paulo. Destas, dá preferência às que ele próprio coletou na Bahia, quando lá esteve em 1937. (...) A composição de invenções, da maneira como é ensinada por Guarnieri, produz um quádruplo e salutar efeito: dá desenvoltura à escrita polifônica; ensina o desenvolvimento temático; aumenta a familiaridade com a melódica brasileira; $e$ ensina o manejo de diversos instrumentos [musicais]”

O maestro italiano, mesmo distante espacialmente do amigo brasileiro, continuaria bastante presente em sua trajetória, nunca deixando de prestar avaliações e conselhos técnicos sobre as peças que Guarnieri lhe enviava por correspondência. A título de ilustração, pode-se observar no seguinte trecho de uma carta de 1969 endereçada a Baldi, época de bastante conforto do compositor brasileiro em relação a sua posição no campo musical nacional e reputação internacional, o lugar que as orientações técnicas do antigo professor mantiveram na autoavaliação de suas peças, bem como a necessidade de compartilhar suas inseguranças e decisões procedimentais:

"Quando a sua carta chegou, eu já estava no meio da partitura do Concerto nº 4. Afinal, resolvi diferente a orquestra. Não usei guitarra elétrica (...) também 
“zampogna” foi eliminada. Afinal, a orquestra ficou assim - $2 \mathrm{Fl}+$ pic, 2 ob + Cor Ing, 2 Cl B, 2 Fag + C. Fag [ 2 flautas + piccolo, 2 oboés + corne inglês, 2 clarinetes em Si, 2 fagotes +2 contra-fagotes], 4 Cornos, 3 trompetes (em Dó), 3 Trombones, 1 tuba, tímpanos, percussão (alguns instrumentos nacionais) celesta, vibrafone, xilofone, harpa, violas, violoncelos e contrabaixos. Não usei os violinos. No início me deu grande trabalho, a fim de me ambientar dentro da orquestra escolhida. Felizmente a "matéria-prima”, como diz você, me facilitou a realização. Assim é que estou no fim do terceiro movimento e esta semana terminarei, creio eu. Assim é que estou gostando muito do resultado, pois agora já posso ter uma ideia do conjunto da obra. O $2^{\circ}$. movimento saiu como você sugeriu, quase solístico para todos os instrumentos e usei uma orquestra menor. Quando você vir a partitura vai gostar, estou certo. A minha alegria é grande, creio que dei um passo à frante” (Guarnieri em missiva a Lamberto Baldi. São Paulo, 19 de fevereiro de 1969. Série de correspondências, Fundo Camargo Guarnieri, IEB-USP)

Conforme discutido, a importância de Baldi para a formação técnica é clara, mas um tanto nublada em relação a seu caráter modernista, isto é, do que foi assimilado por Guarnieri em termos de proposta de renovação da linguagem, visto que também era fortemente influenciado por outros atores. Por ocasião da partida de Baldi do Brasil, o pupilo sofre com o interrompimento brusco das aulas, que corriam de vento em popa, e do afastamento do querido professor que lhe caíra tão bem pelo modo "aberto" e expansivo de ensinar. Durante a passagem de 1931 e 1932, carecendo de orientação, e certamente de alguém que pudesse verificar a qualidade do que escrevia, Guarnieri busca em Mário de Andrade os apurados juízos críticos de ouvinte pelos quais seria aconselhado e, ao mesmo tempo, legitimado, investindo-o do papel de uma espécie de "consciência crítica" de sua obra. Afora a apreciação da pertinência das peças, a partir do maior envolvimento com o intelectual vem, a reboque, a possibilidade de se embrenhar nas análises de partituras constantes do inestimável acervo da biblioteca pessoal; empreendimento necessário à continuidade dos estudos formais, agora autodidatas pelas contingências. Em contrapartida, é provável que Mário de Andrade enxergasse na aproximação os auspícios de investir num jovem tão aberto a oportunidades que lhe valessem espaço na música, para que este contribuísse a contento com seu projeto de liderança. Ademais, um fato pouco conhecido contribui para a aliança entre os dois. Em carta ao poeta Manuel Bandeira de 29 de agosto de 1928, Mário revela que provavelmente só logrou publicar seu conhecido texto Ensaio sobre a música brasileira por conta da proximidade que estava tecendo com Guarnieri, este por sua vez ligado à comunidade de imigrantes italianos que dominavam o mercado editorial especializado em música:

“Mas meu caso agora é que o Ensaio custa 6 contos a edição e careci de campear 
editor. Achei um na casa Chiarato que pelos elogios que tenho feito pra ela, justos, por estar editando as músicas do Mozart Camargo Guarnieri (mocico aparecendo, 21 anos, aluno de composição do Lamberto Baldi e bastante aconselhado por mim na orientação estética, sem ser aluno meu) a casa acho que ficou um bocado comovida e aceitou editar o Ensaio...” (ANDRADE apud. TONI \& SILVA, 2001:245 nota de rodapé 111).

Adiante, Passaremos à análise desse laço, emblemático do feitio das relações de mútua dependência que caracterizaram o modernismo musical em São Paulo durante a década de 30, de grandes oscilações no campo político. 


\section{CAPÍTULO 2}

\section{As décadas de 1930 e 1940: política modernista negociada e as novas colocações}

A década de 1930 pode ser caracterizada na trajetória de Guarnieri como maturação de sua técnica, apesar da insegura escrita orquestral, e expansão da rede de apoiadores de sua música para além dos que encontrava no CDMSP, bem como a cristalização desses aspectos em sua personalidade artística na forma de uma necessidade de ser avalizado por alguém reconhecido do meio - Baldi e Mário de Andrade. Se desde 1928, marco inicial de seu catálogo legítimo, o jovem músico egresso dos salões e cinemas que tanto contribuíram à aquisição prática de muito de seus atributos - como a facilidade em compor melodias e trabalhar ao piano - conjugada à instrução formal dada por Lamberto Baldi, passa a ser considerado e a se considerar um compositor, o período subsequente traria a definitiva entrada nos círculos modernistas - a amizade com Mário de Andrade, Luiz Heitor Corrêa de Azevedo, Curt Lange e Charles Koechlin, a participação na fundação da Sociedade Pró-Arte Moderna em 1932 junto a seu "divisão musical”, ao lado de Mignone, Souza Lima, João Caldeira Filho, Artur Pereira, Guiomar Novais, Antonieta Rudge, Frutuoso Viana e outros. A década de 1930 traria igualmente novos desafios e tensões. Da interrupção dos estudos com Baldi, seria preciso, mais uma vez, buscar meios de contornar a insuficiência institucional de formação erudita; dos poucos espaços públicos dedicados à audição de música de concerto em São Paulo, somados ao interesse limitador dos empresários por companhias de ópera italiana oitocentista que hegemonizavam as apresentações do Teatro Municipal e a fragilidade de organizações associativas como a Sociedade de Concertos Sinfônicos de São Paulo, fazia-se necessário forjar alianças estratégicas com quadros do movimento modernista. Estes possuíam ampla rede de apoiadores no Estado e no empresariado, figurando-se, portanto, como único setor da sociedade capaz de formular e implantar um real projeto de ampliação e institucionalização do campo musical na época - prevendo tanto a construção de espaços fixos de formação e difusão de repertório, visando superar as insuficiências do CDMSP e das sociedades associativas de músicos e fomentadores de concertos, quanto um conjunto complexo de diretrizes estéticas que guiariam a constituição de uma geração de novos compositores brasileiros, cuja produção se referenciaria numa "tradição" entabulada por esse mesmo projeto.

Para se compreender este momento da trajetória de Guarnieri, é preciso começar por retomar o significado de década de trinta para o movimento modernista de 22 , sobretudo as condições que levaram Mário de Andrade ao Departamento de Cultura em meio à efervescência política e cultural do país ${ }^{1}$, e ao estreitamento das alianças dos intelectuais com os círculos de poder.

1 As informações, discussões e referências sobre o Departamento de Cultura foram extraídas dos trabalhos de 
Mário exerceu funções de direção no Departamento Municipal de Cultura de São Paulo entre 1935 e 1938, isto é, ao longo de toda gestão de Fábio de Almeida Prado na prefeitura e Armando de Salles Oliveira no governo do estado. Assim como a Semana de 22, a criação do órgão pelo intelectual foi um projeto apoiado pelas oligarquias paulistas em disputa com os demais grupos dirigentes regionais pela hegemonia no plano nacional; este, no caso, estaria dentro da perspectiva de retomar a liderança cafeeira posta em xeque pelas mudanças políticas e econômicas decorrentes dos fracassos das movimentações de 30 e 32. A partir da ascensão de Getúlio Vargas provocada pela crise de 29 essa fração da classe dirigente paulista passa a empenhar seus esforços em recuperar a hegemonia política em iniciativas por parte do poder público de fomento ao desenvolvimento urbano, populacional e cultural da "capital econômica do país". Daí são criadas instituições como a Escola de Sociologia e Política, a Universidade de São Paulo e, claro, o próprio Departamento de Cultura, cujas inúmeras divisões pretenderam dar conta de formar um arcabouço de conhecimento sobre a cidade para organizá-la e modernizá-la, a fim de se tornar bem-sucedida a experiência local de um projeto para todo o país. Para tanto, era preciso formar nas universidades direções, isto é, um corpo de funcionários públicos especializados capazes de elaborar políticas de governo para transformá-lo, assim como pensar e garantir a implementação prática dessa elaboração, função do Departamento. Caberia a este órgão:

"Não só a reorganização urbanística e populacional da então mais industrializada e desorganizada capital brasileira, mas também a preocupação com o advento das artes e das atividades ligadas ao lazer que ali se desenvolviam, numa tentativa de controlá-las e moldá-las conforme os interesses e os valores do grupo que, vale dizer, concebia sua cidade e seus respectivos moradores de modo técnico e rigorosó, isto é, de maneira cientificista, tal qual em voga no período:

- 'com as pesquisas sociais pretendia-se conhecer a realidade da cidade, diagnosticar seus problemas e propor soluções para a ordenação da vida urbana. A referência à pesquisa como sendo uma possibilidade de ver a cidade por meio o microscópio revela uma percepção de cientificista em que a estatística e a ciência são utilizadas como pretexto de neutralidade no analisar a cidade. A preocupação com a forma pela qual a população vivia não só os momentos de trabalho mas também os de lazer, e a tentativa de controlar e guiar toda essa gama de atividades, apesar de irrealizável, era um dos objetivos que o Departamento tentava alcançar. Essa visão parecia acreditar que a cidade, como um enigma, deveria ser pesquisada, destrinchada e analisada, para então, ser organizada e melhor controlada'.”

(OLIVEIRA, 2005b:12) .

Francini Venâncio de Oliveira (2005a, 2005b) e outros (BARBATO JR, 2004; DASSIN, 1978; RAFFAINI, 2001; NOGUEIRA, 2002). 
O tom de inventariar tudo que integraria um acervo cultural através de procedimentos sistematizados somada "à convicção de que somente pela ciência e pelos critérios racionais de análise a tradição brasileira poderia ser recuperada em seus termos autênticos” (idem:13) confere relevo ao emergente compromisso do papel assumido pelo Estado na montagem de um amplo e ambicioso projeto cultural - que, como dito antes, deveria começar em São Paulo para seguir à transformação do país. No comando dessa nova tentativa da classe dirigente paulista de recuperar o espaço federal através da cultura estão os intelectuais modernistas ligados ao PD, especialmente Paulo Duarte, Sérgio Milliet, Rubens Borba de Moraes e Mário de Andrade. Seus conhecidos engajamentos institucionais só se explicam pelas mudanças das relações entre os grupos dirigentes e os intelectuais ${ }^{2}$. Ao longa dos anos 20 , houve um processo de diversificação de interesses interna às classes dirigentes, gerando correntes de dissidência ao PRP; da Liga Nacionalista, passando pela facção Mesquita do grupo do Estado e sua empreitada editorial Revista do Brasil, até a consolidação de uma frente "liberal" e "modernizadora", o P artido Democrático (fundado em1926), as frações especializadas em funções políticas, técnicas e culturais puderam colher da alteração da correlação de forças em desfavor do regime oligárquico condições de fazer valer seus interesses e projetos. Com efeito,

“As mudanças ocorridas tanto no nível das organizações políticas como no nível das instâncias de produção cultural (que resultaram, por sua vez, na transformação da estrutura de classes) se fizeram acompanhar por uma transformação radical das modalidades de acesso às carreiras dirigentes. De agora em diante não era mais possível valer-se das prerrogativas inerentes ao sistema de reprodução direta que fazia com que a passagem pela Faculdade de Direito constituísse apenas um simples estágio de iniciação ao conjunto de modelos masculinos da classe dirigente e de integração na rede de relações de suas famílias” (MICELI, 2001:93)

As condições de acesso que integraram os intelectuais às instituições do Estado também implicaram o ingresso dos jovens músicos, que encontraram uma outra forma de mecenato, isto é, a subvenção pública das atividades musicais. A passagem do antigo modelo de suporte de mecenas cuja força se enraizava na indistinção do poder das elites oligárquicas como o fornecido por Freitas Valle, do entrelaçamento entre público e privado, favorece principalmente aqueles musicistas de origem imigrante que enveredaram para a composição por não terem chances iguais de se tornarem intérpretes frente às vantagens familiares dos oriundos dos grupos de extração tradicional. Com a diferenciação da esfera política e do campo de produção de bens culturais, estes também passam a depender dos circuitos modernistas - de composição social bem próxima às hostes do PRP, mas já

2 Para construir o histórico dessa relação nos serviremos do trabalho de Sérgio Miceli, Intelectuais e classe dirigente no Brasil (1920-1945). 
com as demarcações internas impostas pelo Partido Democrático. O caso mais expressivo da alteração da hegemonia política que se refletia nos circuitos culturais da cidade logo após a derrocada das forças constitucionalistas talvez tenha sido a experiência da Sociedade Pró-Arte Moderna $^{3}$, cuja “divisão musical” abarcou tanto os célebres pianistas consagrados na década de 20, quanto os jovens compositores ainda por se consagrar. É notável que na estrutura hierárquica dos membros da SPAM tenha se operado a inversão da escala de prestígio não só do meio musical erudito, mas das áreas da música, uma vez que os mais jovens, os compositores, foram alocados pelos modernistas nas posições de lideranças, acima dos pianistas famosos. Foi neste espaço, em que várias peças de Guarnieri e Mignone entraram para a programação de concertos e estreiaram, que os dois se notabilizam enquanto compositores representantes do modernismo. Até então Guarnieri só havia apresentado peças de seu catálogo para um público significativo poucas vezes (em função dos contatos no CDMSP e de Baldi) e Mignone estava mais associado às tentativas da elite tradicional de formar compositores brasileiros de ópera no rastro de Carlos Gomes. Este, assim como Souza Lima e outros, viram seus antigos mecenas perderam terreno, e portanto condições de lhes garantirem espaços no meio musical, para um novo grupo de agentes melhor posicionados no sistema de concorrência política e intelectual.

O estabelecimento de relações de interdependência entre músicos e intelectuais modernistas, ao contrário do que as biografias de Guarnieri sugerem, é repleta de tensões e dissensões em torno do processo de acomodação dos projetos. Em linhas gerais, de um lado, a elaboração de um “inventário das tradições" ligado às questões da construção de uma identidade nacional, por parte dos intelectuais, de outro, os diferentes projetos individuais dos músicos, cujo caso de Gurnieri é emblemático e será explorado na troca de correspondências com Mário mais adiante. No entanto, antes de explorar o franco espaço de negociação em torno das questões do nacionalismo e das soluções estéticas encontradas, é preciso apresentar em quais marcos se deram especificamente as referidas relações de tensão e interdependência sob pena de reincidir tanto nas mistificações biográficas, quanto no senso comum erudito musicológico atinente a "jogos de oposições" da linguagem musical enquanto eixos de análise, o que não é nosso caso aqui.

Primeiramente, os músicos modernistas estavam em franca assimetria, por conta da referida dificuldade institucional de formação, ao mesmo tempo em que tentavam afirmar sua personalidade artística, perante intelectuais de formação reconhecidamente erudita. Sejam "primos pobres”, sejam "homens sem profissão", estes eram provenientes das camadas médias e altas da sociedade, de origem "nobre", portanto tiveram tempo para se dedicar com calma aos estudos e pesquisas de

3 A principal fonte de informações e análises sociológicas consideradas aqui sobre a Sociedade Pró-Arte Moderna é o estudo de Fernando Antônio Pinheiro Filho, Lasar Segall: arte em sociedade. Especialmente os capítulos "A Sociedade Pró-Arte Moderna" e "Na spamolândia". 
assuntos variados, além de dispor de recursos como amplas bibliotecas pessoais, professores particulares, fluência em francês, etc. Também o capital social adquirido das condições familiares lhes seria favorável às carreiras possíveis dos intelectuais na imprensa e no funcionariado público, em funções de crítica cultural e assessoria política. Sujeitos como Mário de Andrade, Sá Pereira, Luiz Heitor e Andrade Muricy tinham igualmente se formado em música praticamente na mesma época que Mignone, Guarnieri ou Souza Lima, enfrentando as mesmas dificuldades e desestímulos do meio musical para seguir adiante em carreiras de intérprete, regente ou compositor. Tendo condições de acesso a outras carreiras, e se valendo do investimento intelectual, optam por direcionarem suas atividades na música às áreas de pesquisa, crítica e pedagogia, tornando-se musicólogos, professores, historiadores e críticos de peso no cenário musical por contribuições relacionadas à organização de sociedades de concerto, edição de revistas de música, publicação de artigos suscitadores de debates sobre estética e problemas da institucionalidade do ensino musical, edição de partituras, pesquisa etnomusicológica "folclorista" e etc. À guisa de ilustrar o caráter de parte dessas contribuições, que veio a integrar o projeto modernista de Mário de Andrade para o meio musical, há o exemplo do papel da formação musical problemática, comum aos compositores, vivenciada e elaborada criticamente pelos intelectuais:

"Eles [os intelectuais] também viveram em tensão com as limitações institucionais e o escolasticismo muito inflexível que dominava instituições como o Conservatório de São Paulo ou o Instituto Nacional de Música do Rio de Janeiro. A antropóloga Elizabeth Travassos já propôs, num estudo comparativo entre a realidade brasileira e a do leste europeu deste início de século XX [Os mandarins milagrosos: arte e etnografia em Mário de Andrade e Béla Bartók.], que a pesquisa etnográfica e as teorizações sobre o uso das falas populares na composição musical moderna foi derivada, em grande medida, da situação de insatisfação com o ensino musical disponibilizado pelos conservatórios do Brasil e da Hungria” (EGG, 2010:79)

Em contrapartida, o acesso aos círculos de poder logrado pelos músicos, colhido da movimentação nos círculos modernistas, facilita a complementação de suas formações. Por um lado, por meio do aberto favorecimento desses músicos na seleção de candidatos ao pensionato público - selecionados por bancas formadas por colaboradores muito próximos - podem se instruir e se apresentar no exterior. Guarnieri vai tardiamente à Paris, de 1938 até o acirramento das tensões em 1939 causado pela Segunda Guerra, a fim de estudar com Charles Koechlin e François Rühlmann; com aquele teve aulas de contraponto, fuga, orquestração, estética musical e instrumentação, com este, regência de orquestra e coral. Por outro lado, a complementação da formação se dá pela prática musical empreendida à frente dos novos conjuntos fixos criados, como 
é o caso do Coral Paulistano e de uma orquestra do Departamento de Cultura, frutos da gestão de Mário. Apesar da orquestra e outros conjuntos não sobreviverem ao final do mandato, é fato conhecido que, durante a gestão do prefeito Fábio Prado, Mário de Andrade encabeçou uma série de iniciativas de dinamização das atividades musicais na cidade:

“A 31 de maio de 1935 Mário de Andrade fora nomeado Diretor do Departamento de Cultura e Chefe da Divisão de Expansão Cultural, acumulando, portanto, as duas funções. Como Diretor, seguia de perto o que ia acontecendo nas demais Divisões: a de Biblioteca, Educação e Recreio, e a de Documentação Histórica e Social. Em sua própria Divisão, acompanhava o dia-a-dia das Seções de Teatro e Cinemas e da Discoteca Pública. Durante os três anos em que se mantém à frente de seus postos destacam-se, na esfera musical, a criação das entidades: Coral Paulistano, Madrigal, Coral Popular, Quarteto, Trio, a estruturação de uma orquestra dando origem à atual Orquestra Municipal de São Paulo [que só se tornaria evetiva na década de 1940], além da promoção de concursos para obter peças novas destinadas ao repertório das diversas formações instrumentais e/ou vocais. Outros fatos devem ser mencionados devido a suas importâncias no panorama musical brasileiro: em 1937, a realização do Congresso da Língua Nacional Cantada; em 1938, o envio de uma equipe de pesquisadores para o Norte e Nordeste, a Missão de Pesquisa Folclóricas (...). Para dirigir o Coral Paulistano, Mário nomeou Camargo Guarnieri, em 1935, posto que o compositor manteve até sua ida para a França, em 1938, quando foi substituído por Frutuoso Viana" (SILVA, 2001:219, nota de rodapé).

Alguns desses corpos estáveis ficaram sob a batuta de Guarnieri, conforme citado, o qual pôde tirar todo o tipo de proveito da situação privilegiada para qualquer compositor de ter ao seu inteiro dispor conjuntos diferentes e completos que executassem parte de suas peças recém-criadas, ou de seu recente repertório, a fim de testá-las e retrabalhá-las in loco. Assim, o compositor pôde ganhar experiência no manejo do conjunto orquestral, habilidade que, como anteriormente dito, faltava-lhe. O Coral Paulistano deveria se dedicar à música exclusivamente vocal, a fim de forjar uma tradição coral ainda inexistente. Já a orquestra foi montada em parceria com a Sociedade de Cultura Artística (associação privada da qual Mário de Andrade também fazia parte) a partir dos concertos sob regência do maestro alemão convidado Ernest Melich. Mais tarde, na década de 1940, essa orquestra se firmaria, finalmente se vinculando ao Teatro Municipal. É notável, portanto, a situação favorável de Guarnieri se comparada às condições ainda precárias dos intérpretes participantes dos concertos regidos por maestros estrangeiros ou Villa-Lobos, da Sociedade de Concertos Sinfônicos e da Sociedade de Cultura Artística. Estes não tinham estabilidade 
profissional, e ainda davam aulas particulares e tocavam em concertos, óperas ou cinemas; não recebiam salários por ocasião dos concertos de iniciativa das duas sociedades sinfônicas de São Paulo. Deviam, ao contrário, contribuir como sócios dessas entidades associativas, enquanto mantenedores das temporadas.

Com efeito, supriam-se temporária e muito restritamente algumas das carências do cenário paulista da música de concerto à formação de compositores, quais sejam, as possibilidades de ouvir concertos, regê-los, ouvir a execução de peças próprias e debatê-las com os críticos - para além das aulas de harmonia e contraponto. Em São Paulo, a partir de base institucional mínima criada pelo Departamento de Cultura, é que se torna possível constituir uma pequena geração de compositores eruditos, ao invés do surgimento no varejo de um compositor ou outro, anteriores aos modernistas, ligados ao Império ou às hostes perrepistas, que geralmente precisavam trocar a cidade pelo Rio de Janeiro, ou mesmo o exterior, a fim de viabilizarem carreiras de criação. Talvez se deva à falta de vitalidade do meio musical erudito do início do XX o insucesso do projeto de formar compositores no Conservatório Dramático, projeto advindo das discussões infrutíferas e disputas iniciadas por entidades representativas dos músicos no final do XIX, que não conseguiam obter consenso sobre quais interesses e direitos defender, nem em quais questões se centrar para efetuar a organização da atuação profissional. Como já dissemos, o CDMSP só seria finalmente viabilizado em 1906 por iniciativa do vereador Pedro Gomes Cardim, enquanto entidade associativa, angariando os fundos negados pela prefeitura entre apoiadores da tradicional elite política e músicos ilustres, além de que se limitava a formar intérpretes e professores, sobretudo de piano, com seu quadro docente composto majoritariamente pelos mesmos professores imigrantes italianos que, antes da fundação do Conservatório, davam aulas particulares sem grandes preocupações de elaborar um projeto pedagógico comum.

Um segundo fator de tensão implicada na relação de interdependência era a diferença de condições de acesso ao poder entre intelectuais e jovens compositores. A começar, o nem sempre convergente alinhamento político dos círculos de sociabilidade dos intelectuais e dos músicos, por vezes rivais, no caso de alguns compositores de outras cidades (Villa-Lobos e Frutuoso Vianna). Com efeito, há exemplos de rupturas dessa relação interdependente, como se averígua na primeira colaboração entre Mário de Andrade e Villa-Lobos na década de 1920 (especialmente por ocasião da Semana de 22). A colaboração entre Mário de Andrade e Villa-Lobos atravessaria na década seguinte certas turbulências, como os concertos malsucedidos de Villa-Lobos em São Paulo, organizados pelo intelectual em 1931, até culminar finalmente no esgotamento do apoio mútuo, quando Villa-Lobos se afasta do círculo modernista de Mário de Andrade para encampar projetos junto ao governo de Getúlio Vargas, no Distrito Federal. Em 1932, Villa-Lobos assume a 
Superintendência de Educação Musical e Artística (SEMA), onde implementaria seu projeto de canto orfeônico no sistema de ensino básico local, para dali ser expandido ao resto do país. Sob a tutela do Estado Novo, o compositor trabalharia de maneira extremamente centralista, reduzindo suas parcerias a colaboradores que lhe fossem subordinados:

"Quando implantou o Conservatório de Canto Orfeônico - que formaria os professores, foi ele mesmo o diretor, o elaborador dos programas de ensino e o professor. O Orfeão dos Professores, conjunto vocal formado para participar dos eventos cívico-patrióticos promovidos pelo governo de Getúlio Vargas, era dirigido pelo próprio Villa-Lobos, bem como a orquestra formada para também participar destes eventos - que seria chamada 'Orquestra Villa-Lobos'”. (EGG, 2010:87)

Ao se dar conta da personalidade um tanto individualista e personalista que Villa-Lobos desenvolvera como artista, e de se afastar dele por conta de diferenças políticas atinentes ao varguismo e a Revolução de 30, Mário de Andrade passa a investir no direcionamento estético dos compositores mais novos e paulistas, Mignone e Guarnieri. Presta-se, pois, a orientá-los e apoiá-los, seja ao lhes delegar incumbências e funções nas instituições recém-criadas, seja levando a conhecimento público as peças por meio de críticas em suas colunas nos jornais, ou até mesmo contribuindo diretamente à produção com letras de canções e libretos de óperas. Pode-se concluir que o recrutamento de compositores paulistas se deu tanto pela aproximação prévia nos circuitos culturais perrepistas de seus mecenas em comum nos anos 20, quanto pelo distanciamento que as alianças políticas antagônicas à hegemonia de São Paulo impusera entre os agentes ligados ao PD, que tomaram parte na "Revolução Constitucionalista", e os músicos cariocas e mineiros colaboradores de 22, agora alinhados ao varguismo. A aproximação dos intelectuais modernistas ao governo de Getúlio Vargas só se deu após o golpe de 37 e a derrocada de seu projeto no Departamento de Cultura. Assim sucedeu aos compositores paulistas, sobretudo a Guarnieiri, que perderam seus cargos após o golpe e precisaram acionar os contatos com as frações modernistas do Rio de Janeiro para se realocarem. Mignone se antecipa ao se estabelecer no Rio logo após o fracasso de São Paulo em 32, mudando-se em 1933 talvez porque não enxergasse mais modos de obter oportunidades dos velhos patronos, conjugada à liderança assumida por Guarnieri, muito mais próximo de Mário de Andrade do que ele. Em que pese as atividades por anos a frente da cadeira de regência do Instituto Nacional de Música, pôde ainda assim ser contabilizado como compositor modernista pela crítica da época por conta da preservação dos vínculos com Mário de Andrade, visíveis no reconhecimento obtido na SPAM, nas tantas peças que compôs em colaboração direta com o amigo, mesmo à distância, e nas apresentações de obras suas nos espaços ligados ao Departamento. 
Tendo em vista os catálogos dos dois compositores, percebe-se que, muito provavelmente, a primeira colaboração musical com os modernistas tenha se dado em torno da Revolução Constitucionalista de 32, quando Mignone escreve o Hino das tropas constitucionalistas e Guarnieri compõe A morte do aviador (cantata sobre poema de Mário de Andrade enaltecendo Gomes Ribeiro), Piratininga e Em Memória dos que morreram por São Paulo. Em missiva de 2 de setembro de 1932 a Guarnieri, Mário de Andrade requisita ao jovem o que viria a ser À glória de S. Paulo, hino sobre texto de Menotti del Picchia:

"Você quer ver se faz um Hino a São Paulo? Preciso disso com certa urgência, pois é para ser lançado na Record dia 7 de setembro. O mais tardar, a composição deve ser entregue a mim dia 5 de manhã. Faça a música que sobre esta serão escritos os versos. Assim você terá mais liberdade de inspiração”. (ANDRADE In TONI \& SILVA, 2001:199)

Não é de se estranhar a urdidura de laços em torno das movimentações políticas a que o Partido Democrático estava ligado. Segundo Paulo Duarte em seu livro sobre Mário de Andrade ${ }^{4}$, as discussões que embasaram o projeto de institucionalização da música aplicado ao Departamento haviam sido em boa medida travadas em seu apartamento ao longo de toda a década de 20 e início de 30, ou seja, durante a fermentação dos ideais de hegemonia paulista. No entanto, a condução das políticas no Departamento passa por uma ambiguidade, qual seja, a recusa da "política" por esse grupo de intelectuais como força mediadora da construção de um domínio mais autônomo aos campos culturais que, neste sentido, é compreensível a partir da situação anterior restrita à hegemonia perrepista das elites nestes campos. Sobre essa ambiguidade, o historiador Roberto Barbato afirma:

"Desse modo, o Departamento de Cultura acaba por ser a convergência dos esforços e das expectativas desses intelectuais que expressam, a partir dos objetivos da instituição, o desejo de democratização não só da cultura, como da vida nacional criação de cursos populares, piscinas públicas, bibliotecas públicas, preservação de documentos antigos e dados histórico-sociais. Mas além desses elementos expressos, aquilo que se constitui na finalidade principal da empreitada: a construção da nação por meio da cultura independente da mediação política” (BARBATO, 2004:11).

Conforme salienta Francini Oliveira, a separação entre as esferas políticas e culturais faz parte do ideário balizador dos projetos modernistas quando da aceitação de convites para assumir cargos públicos e prestar assessoria a políticos, sendo que no acúmulo histórico, os rumos à modernização cultural pressupuseram estreita articulação entre ambos os domínios. Prova disso

4 DUARTE, Paulo. Mário de Andrade por ele mesmo. São Paulo, Hucite,1977. 
seriam a dimensão que categorias simbólicas como "povo" e "nação" ganharam, fruto da indissociável experiência dos intelectuais a frente de órgãos governamentais com os projetos de unificação da classe dirigente do período (cf. OLIVEIRA, a2005).

Afora a estrita ocasião mencionada, outras parcerias menos explicitamente engajadas e contingenciais datam deste momento e prosseguem até a estadia em Paris, no intervalo compreendido entre 1932 e 1938. Guarnieri registra em seu catálogo várias parcerias com o intelectual modernista, em inúmeras canções compostas sobre poemas já escritos; a parceria mais direta seria Pedro Malasarte, ópera de 1932. Teve seu libreto escrito em 1928, mas todo o trabalho de Guarnieri foi acompanhado de perto pelo autor do texto. É emblemático que a Abertura da ópera, fruto da parceria quase direta, tenha sido executada logo nos primeiros concertos promovidos por Mário de Andrade à frente do Departamento de Cultura. Quanto à relação com Mignone, houve parcerias artísticas que fixariam a fama do compositor enquanto inventor de um "sinfonismo afrobrasileiro", fruto do aconselhamento estético do intelectual, em peças como Maracatu do Chico Rei (1933), Babaloxá (1936), Batucajé (1936) e Leilão (1941) (cf. idem:87).

Contudo, ao longo do desenrolar da convivência e das orientações, entrevê-se o aparecimento de várias divergências entre os amigos sobre temas estéticos, o valor de certas produções estrangeiras, a apropriação do significado inovador da escrita polifônica, etc. Muitas dessas divergências foram registradas na correspondência entre eles. Apesar de manterem encontros semanais, debatendo os referidos assuntos no convívio pessoal, Mário de Andrade fazia questão de deixar as discussões mais densas para as cartas, instigando o amigo a lhe escrever caso quisesse aprofundar as conversas pessoais. O epistolário, assim como ensaios e críticas faziam parte do redirecionamento que o intelectual impõe a sua produção entre 1928 e 1932, concentrando-se na "obra de circunstância" e se distanciando da "arte desinteressada"; inflexão marcada pelo engajamento nos assuntos culturais e em atividades públicas, bem como pela redação em 1928 do texto Ensaio sobre a música brasileira - reflexão estética balizada por incursões teóricas a certas produções populares e a materiais musicais, conjugada à avaliação dos rendimentos dos novos compositores de acordo com o que Mário chama de "valor nacional" da produção. Para compreender o pano de fundo das ideias que orientam os apontamentos do intelectual, precisamos retomar elementos contidos no Ensaio.

Logo de início, o autor faz "a crítica da crítica", chamando a atenção para o que lhe desagrada nos critérios dos pares modernistas para julgar o valor de peças recém-produzidas:

"Nós, modernos, manifestamos dois defeitos grandes: bastante ignorância e leviandade sistematizada. (...) O que deveras eles gostam no brasileirismo que exigem a golpes duma crítica aparentemente defensora do patrimônio nacional, não é a ex- 
pressão natural e necessária duma nacionalidade não, em vez é o exotismo, o jamais escutado em música artística, sensações fortes, vatapá, jacaré, vitória-régia” (ANDRADE, 1972:13-14).

Em seguida, atribui o exotismo presente nas avaliações à projeção do que seria apreciado, e portanto legitimado, na Europa. :

"Mas um elemento importante coincide com essa falsificação da entidade brasileira: opinião de europeu. O diletantismo que pede música só nossa está fortificado pelo que é bem nosso e consegue aplausos estrangeiros. Ora, por mais respeitoso que a gente seja da crítica europeia carece verificar duma vez por todas que o sucesso na Europa não tem importância nenhuma pra Música Brasileira. (...) ” (idem:14).

Logo depois, explicita a referência aos descaminhos da personalidade de Villa-Lobos “o índio de casaca" celebrado em Paris, porquanto afeito ao espírito primitivista cultivado pelas vanguardas parisienses. Ao mesmo tempo que lhe lança críticas por ir a reboque dos fluxos de legitimidade, tenta "defendê-lo se si mesmo", digamos, ao enaltecer sua obra:

“Mas no caso de Villa-Lobos por exemplo é fácil enxergar o coeficiente guassú com que o exotismo concorreu pro sucesso atual do artista. H. Prunières [crítico francês] confessou isso francamente. Ninguém não imagine que estou diminuindo o valor de Villa-Lobos não. Pelo contrário: quero aumentá-lo. Mesmo antes da pseudomúsica indígena de agora Villa-Lobos era um grande compositor. A grandeza dele, a não ser pra uns poucos, sobretudo Artur Rubinstein [célebre pianista, cumpriu importante papel na divulgação de Villa-Lobos no começo de sua carreira] e Vera Janacópulos [célebre cantora que, assim como Rubinstein, ajudou o compositor nos primeiros passos], passava despercebida. Mas bastou que fizesse uma obra extravagante bem do continuado para conseguir o aplauso.

Ora, (...) por causa do sucesso artístico mais individual que nacional de Villa-Lobos só é brasileira a obra que seguir o passo dele? O valor normativo de sucessos assim é quase nulo. A Europa completada e organizada num estágio de civilização, campeia elementos estranhos para se libertar dela mesma. Como a gente não tem grandeza social nenhuma que nos imponha ao Velho Mundo (... ), o que a Europa tira da gente são elementos de exposição universal: exotismo divertido. Na música, mesmo os europeus que visitam a gente perseveram nessa procura do esquisito apimentado.”

Critica o compositor carioca também por seu "sucesso artístico mais individual que nacional", o que aqui ganha o sentido de posição demarcada contra um modelo de modernismo que se destacava de sua zona de influência para alçar voos independentes e competir elo interesse de 
seus discípulos, afinal o carioca galgava posições junto às classes dirigentes que se alinhariam nos anos 30 contra São Paulo. Depois de apresentar um panorama da música brasileira, e de tratar das fontes possíveis do material musical, divide seu texto entre cinco parâmetros da linguagem musical: "Ritmo", "Melodia", "Polifonia", "Instrumentação" e "Forma". Em cada uma dessas partes, procede da mesma maneira, qual seja, principia por "esclarecer" mal-entendidos em relação ao que é nacional ou não de acordo com o estágio de desenvolvimento da música, e apresenta um breve balanço de como os compositores menos e mais recentes lidaram com tais questões. Concomitantemente ao apontamento das insuficiências e méritos destes, destrincha potenciais questões dos parâmetros musicais a serem trabalhadas, ou mesmo solucionadas:

"Pode-se dizer que o populário musical brasileiro é desconhecido até de nós mesmos (...) Luciano Gallet está demonstrando já uma orientação menos regionalistas e bem mais inteligente com os cadernos de Melodias Populares Brasileiras (ed. Wehrs e Cia. Rio) porém os trabalhos deles são de ordem positivamente artística, requerendo do cantor e do acompanhador cultura que ultrapassa a meia-força. E requer o mesmo dos ouvintes. Se muitos desses trabalhos são magníficos e se a obra folclórica de L. Gallet enriquece a produção artística nacional, é incontestável que não apresenta possibilidade de expansão e suficiência de documentos para se tornar crítica e prática. Do que estamos carecendo imediatamente é dum harmonizador simples mas crítica também, capaz de cingir a manifestação popular e representá-la com integridade e eficiência” (grifo meu, idem:20-21).

Ou ainda:

“Onde já os processos de simultaneidade sonora podem assumir maior caráter nacional é na polifonia (...) O problema é sutil e merece muito pensamento, muito raciocínio de nossos artistas. Quanto aos processos já europeus de polifonia eles são muito perigosos e na maioria das feitas descaracterizam a melodia brasileira (...)É o que a gente pode observar no 'Sapo Jururu' tratado por Villa-Lobos nas Cirandas $\mathrm{n}^{\mathrm{o}}$ 4, 'O Cravo brigou com a Rosa' (ed. C. Artur Napoleão) e mais fortemente ainda na 'Puxa o Melão' de Luciano Gallet (Melodias Populares, ed. cit.) na qual a repetição canônica no acompanhamento, da própria melodia principal, apesar do brasileirismo incontrastável desta, assume o aspecto de mera retórica europeia. Também no $1^{\circ}$ Tempo do 'Trio Brasileiro' de Lourenço Fernandez (...)." (idem:52-54).

Também previa a melhor postura diante de escolhas fundamentais que acabariam se apresentando àqueles que produzissem música brasileira:

“(...) e se o artista (...) reconhece que não é gênio, então é que deve mesmo de fazer arte nacional. Porque incorporando-se à escola italiana ou francesa será apenas mais um na fornada ao passo que na escola iniciante será benemérito e necessário. 
Todo o artista brasileiro que no momento atual fizer arte brasileira é um ser eficiente com valor humano. O que fizer arte internacional ou estrangeira, se não for gênio, é um inútil, um nulo. E é uma reverendíssima besta” (idem:19)

Com efeito, a primeira parte do Ensaio, de entabulação do que é e o que deixa de ser "música de valor nacional”, pode ser reinterpretada à luz das perspectivas desenvolvidas ao longo deste estudo. Imbuído de planos para as artes, Mário tinha antes de tudo, um ambicioso projeto de liderança intelectua que, no caso da música, caracterizou-se pela eleição de seguidores "em formação" que lhe correspondessem as expectativas de reverência em troca da chancela modernista, sobretudo porque não teriam outros espaços assim. Ao construir a crítica aos três compositores mais influentes na época, Villa-Lobos, Lorenzo Fernandes e Luciano Gallet, todos modelos de "modernismo" concorrentes e passíveis de inspirar influências, ressaltando o que neles é valoroso e o que é repreensível, Mário faz do seu texto um verdadeiro jogo normativo de orientações, de modo que se dispõem a "ajudar" os novos músicos a cavarem um modelo alternativo que dê conta das insuficiências daqueles disponíveis. $\mathrm{O}$ tom um tanto professoral com que conclui a primeira parte, que lembra vagamente aquele com que avaliou os trabalhos de Guarnieri e Mignone em artigos para a imprensa, evidencia a posição superior em que se coloca em relação aos compositores, especialmente os jovens promissores - aqueles que já estavam sob sua orientação; em contraposição aos intérpretes "virtuoses", os pianistas mais organicamente ligados à oligarquia que almejaram as bolsas do Pensionato para se formarem e se projetarem no exterior:

"Mas este ensaio vai acabar menos amarguento. O Brasileiro é um povo esplendidamente musical. Nosso populário sonoro honra a nacionalidade. A transformação dele em música artística não posso dizer que vai mal não, vai bem. Figuras fortes e moças que nem Luciano Gallet, Lourenço Fernandes e Villa-Lobos orgulhavam qualquer país. (...) Os mais novos aparecendo agora se mostram na maioria decididos a seguir a orientação brasileira dos três mestres que me serviram de documentação neste livro. Dos nossos virtuoses, alguns notabilíssimos, não honro estes não: me interessam e glorifico principalmente aqueles uns que não sacrificados ao ramerrão da plateia internacional, guardam memória dos nossos compositores nos programas deles. A única bereva de nossa música é o ensino, pessimamente orientado por toda a parte..

(...) A minha obra desde Pauliceia Desvairada é uma obra interessada, uma obra de ação. Certos problemas que discuto aqui me foram sugeridos por artistas que debatiam-se neles, Outros mais fáceis entram no meu trabalho para que meu trabalho possa remediar um bocado a invalidez dos que principiam.” (idem:72-73).

Mário de Andrade se esforçava em orientar Camargo Guarnieri, tanto para que este não 
perdesse de vista o projeto de "música de valor nacional" idealizado, não incorrendo nos "erros" do modelo de Villa-Lobos, quanto para fazer dele uma das figuras representativas da nova geração modernista, combatendo os traços personalistas do por vezes genioso jovem.

Um episódio conhecido do epistolário se dá por ocasião da avaliação hesitante da Segunda Sonata para violino e piano (1933) feita por Mário de Andrade. A peça tem sua estreia no " $1^{\circ}$ concerto oficial" da Sociedade Pró-Arte Moderna, ao qual o intelectual não esteve presente. Todavia, a partir da leitura da partitura, tece os seguintes juízos em carta de agosto de 1934:

"Li a Sonata, retoquei pedaços e fico atônito. Fico sem opinião. É certo que sinto dentro de mim que não chego a gostar. Mas também é a mais leal das realidades que também não chego a não gostar. Isso quererá dizer que fico indiferente diante da arte que a Sonata me proporciona. Não, fico esquecido! (...) Verifico pois que ela não é essencial, não é uma coisa necessária”.

Associando seu desconforto em relação à peça a traços da personalidade artística do jovem, enxerga com restrições os rumos do espontaneísmo romântico e do gosto "dos procedimentos pelos procedimentos", aconselhando-o a se ater em pesquisas de material e aliar inventividade técnica à expressividade verdadeira de ideias e sentimentos:

“Isso está me preocupando um bocado na obra de você. Você está moço e por isso sente aquela facilidade natural de compor da mocidade, e está compondo demais. $E$ o que é pior, compondo com muita rapidez. É raríssimo você voltar sobre uma obra já feita e recompô-la. (...) Isso, além de mostrar uma suficiência de si mesmo que é perigosíssima pra um artista, prova principalmente que você não reage diante da sua própria invenção. A invenção pra você psicologicamente ainda é aquele fato romântico, uma coisa sagrada. Você não reflete sobre, não se controla (...) Digo mais: você está sendo inteiramente escravizado pela sua invenção, ou, o que é pior, por aquilo que você pensa que é a invenção, e não é, é apenas a falsificação intelectual da invenção. Me explico. Uma pessoa aprende a compor, como aprende a fazer versos ou escultura. Bem, adquiriu o ofício. Este ofício, este métier, que é utilíssimo e valoriza, vai valorizar a invenção (veja sobre invenção, a explicação psicológica que dei na Escrava que não é Isaura) esse métier é também perigosíssimo porque muitas vezes ele não é apenas prático e ajuda a fazer a parte técnica da obra, mas é também intelectual, e ajuda a fazer a parte espiritual, digamos assim, da obra, isto é, aquela parte em que ela deriva essencialmente da invenção. E com isso, o métier vai se introduzindo sub-repticiamente no nosso ser psicológico, e ameaça substituir a invenção. A gente pensa que está inventando um tema, uma polifonia, em vez, não está, é o métier, é a habilidade de fazer que está fazendo. Não se trata pois dum apelo profundo do ser, dum grito necessário, duma verdade lírica fruto de sofrimento 
de gozo ou mesmo de reflexão: se trata sim da macaqueação de tudo isso, feita pela habilidade técnica [grifo meu]"

Persiste em se fazer entender, tão logo passa à crítica da escrita difícil do jovem e à avaliação da Segunda Sonata:

"A gente, dotado dessa traiçoeira habilidade técnica intelectual, não apena imita Camões ou Chopin, não apenas imita o profundo e o gracioso, mas acaba se imitando a si mesmo (...) Pode ser que esteja enganado, mas a minha sensação diante desta Sonata, como diante de muitas outras obras da sua já enorme produção, é que você está se imitando a si mesmo. (...) Você, se sua própria essência psicológica já é um escritor difícil, um compositor sem grandes faculdades de amabilidade, que agradem a toda a gente. Você de si é um compositor de elites pequenas. Mesmo quando a invenção de você é amável, como no caso do Impossível carinho ou da modinha da Sonatina, você arreia a melodia de contrapontos e dissonâncias, sem disfarce, duma dureza saliente, que torna imediatamente rebarbativa pra generalidade do público o que era no entanto inicialmente de fácil compreensão. Você tem o horror do agradável, por causa desse perigo do agradável que é se confundir com o banal. Está muito bem, esse horror, antes o medo do agradável é mais que justo e nobilita um artista. (...) Pego na Sonata e leio o tema iniciado pelo piano. Estamos nitidamente em mi maior. Toco, canto, e sei que compreendo a frase, a frase é minha me pertence. Gostei? (...) Gostei en passant (...) Pego no contraponto que você pôs embaixo da frase. Toco ele sozinho. Não me diz nada (...) Não negarei, Deus me livre! Que de vez em quando surge um efeito, um elemento melódico, uma partezinha de polifonia, que me agrada. (...) A lógica é puramente analítica, isto é, existe lógica só quando a gente analisa, e não quando a gente escuta. (...) No Segundo tempo, me horroriza desde logo, essa vontade do mal, essa perversão que hoje reputo incontestável que é a dissonância pela dissonância. Que quer dizer, meu Deus! Esse elemento acompanhante iniciado pela mão direita e que com uma malvadeza sadista se prolonga e muda de notas com uma malvadeza insuportável durante duas páginas. O que é isso! Não é musicalmente nada. Tecnicamente são dissonâncias. Mas você levado pela mania da dissonância, do cromatismo, da alteração que acabou dissolvendo a função harmônica da dissonância, perdeu totalmente as estribeiras. (...) Ora eu não consigo perceber nenhuma razão nem de invenção, nem intelectual, nem harmônica, nem rítmica, nem mesmo puramente técnica que justifique esse ondular vazio de nona e sétimas. (...) Mas aí se introduz o problema mais terrível da música do nosso tempo: o atonalismo. É a libertação da tonalidade e consequentemente do acorde que criou essa epidemia da alteração, que acabou usando a alteração pela alteração, isto é, sem nenhuma razão humana. (...) Não 
nego o valor da alteração, está claro. Porém a alteração gratuita, só para fugir a um som esperado, é um erro. Porque se o som era esperado, ou era porque era essencial ou então porque era lugar-comum. Ora no primeiro caso tirá-lo é destruir a essencialidade. No segundo é apenas mascarar a realidade (...) A terceira página do andante é uma delícia. A única verdadeira invenção de toda a Sonata. E, você repare, é a mais simples, a mais verdadeira. A mais sem complicações”

E sintetiza os elementos que o desagradam à guisa de concluir a carta e instigar resposta:

“(...) é uma obra cheia de cacoetes modernistas e cacoetes seus. Uso da dissonância pela dissonância, gratuitamente. Abuso da alteração, atingindo um atonalismo perigoso. Abuso da interpretação modulatória. Abuso da síncopa, abuso da sétima abaixada, isto é, abuso do brasileirismo, ou melhor, falsificação do brasileirismo. Abuso da apoiadura, que você tirou e sistematizou de certas passagens de Villa Lobos. Falta de controle, principalmente falta de controle temático. Seus temas são aceitos sem reflexão sobre se são realmente temas, ou simplesmente frases ou motivos. Eles não provocam desenvolvimentos que se sustentem por si, que sejam criações novas. (...) Pode realmente existir atonalismo?” (ANDRADE In TONI \& SILVA, 2001:201-208).

É bem provável que Mário de Andrade enxergasse o risco do encanto suscitado pela exitosa trajetória de Villa-Lobos, preocupando-se com uma possível perda de influência sobre o jovem para o outro modelo, tão criticado no Ensaio. Ou mesmo para os encantos experimentalistas de correntes do modernismo europeu, tais como as que Guarnieri conhece pelo contato com Baldi e pelos estudos no acervo pessoal de Mário, ao se embrenhar nas partituras, discos e revistas especializadas européias, as mais recentes possíveis. O entusiamo de Guarnieri por Stravinsky e Hindemith desagradava as expectativas pela inventividade polifônica à brasileira, solução de problemas de prosódia da língua portuguesa para a constituição de uma tradição coral, entre outras questões, nutridas pelo autor de Ensaio. Em resposta às críticas e questões levantadas, Guarnieri responde:

"Você me pôs umas pedrinhas nos sapatos, com sua carta (...) Nunca pensei que a minha $2^{\mathrm{a}}$ Sonata para Violino e Piano lhe provocasse toda essa eclosão de problemas estéticos, que muito me preocuparam. Se você ficou atônito com a sonata, imagino as pessoas que a ouviram lá no concerto da Spam, como devem ter sofrido!... Usando do mesmo direito seu, respondo na medida das minhas forças, mesmo porque responder a sua carta e assumir responsabilidades dos argumentos em réplica aos seus, é qualquer coisa de sério! O que me dá coragem é a ânsia de saber, para poder esclarecer alguns pontos obscuros na minha obra."

Desta feita, após as devidas reverências, o compositor discorre sobre seu processo de 
criação. Há na carta comentários de Mário, que estarão sinalizados por “[“"”]” quando forem pertinentes:

"Quando escrevo, nunca o faço porque quero, sempre uma força, uma vontade interior me obriga a isso. Nesse primeiro impulso, nem penso na forma. Naturalmente quando já estou escrevendo, de acordo com as possibilidades do material (temático) ["portanto reconhece que temas têm + ou - possibilidades"] é que se vai processando o desenvolvimento e consequentemente determinando a forma. Vamos aos caso da $2^{\mathrm{a}}$ Sonata na qual você não encontrou justificação artística. Quando comecei a escrevê-la, confesso a você, eu não pensei que com a continuação ela se tornasse uma sonata.[ "É o mal. Só a inspiração é subconsciente. Em seguida é na consciência que pela análise e concepção do moto lírico se processa a noção da obra e esta se esboça e fica concebida"]

Comecei a trabalhar uma peça para piano e depois de alguns compassos, senti a falta de um outro instrumento que respondesse e repetisse ["Que absurdo de desleixo criação. Não sabia o que ia fazer! Quanto à repetição e resposta temática (...) veja como estava se deixando levar por alguma coisa que era simplesmente memória... muscular, memória técnica, uso de cachimbo, tudo sem necessidade íntima, ou lógica natural dos temas. Puro impressionismo, e o que é pior, dentro do vício formalístico exterior"] o que havia já feito o piano e nesse momento, veio-me à mente o violino, como poderia ter sido outro qualquer instrumento. Continuando a escrever, senti que já estava preparando a entrada dum segundo tema e achando que havia lógica nisso e sentindo a possibilidade de desenvolvimentos idealizei a dita sonata. Aliás, essa sequência não foi premeditada conscientemente, talvez de acordo com você mesmo, quando na Escrava que não é Isaura (...) disse isto: 'o princípio da associação é utilizado pela música há séculos (...) exposto um tema, o músico deixa-se levar por uma série de associações de imagens sonoras que o reconduzem ou ao mesmo tema (rondó, fuga) ou a um segundo (alegro de sonata)'. Você achou que o tema era fraco, gostou en passant, e disse mesmo 'não ser um tema, ser mais uma frase, e principalmente não ser um tema inicial dum alegro de sonata'. Quanto à beleza, a gente pode gostar ou não, achar que é en passant etc. Mas achar que não serve para início de uma sonata já é mais difícil. Eu acho que qualquer tema, frase ou motivo pode servir de início a qualquer forma musical, dependendo naturalmente da maneira que o artista o concebeu. É muito difícil a sua afirmativa! É verdade que em muitos casos, principalmente tratando-se de uma anacruse, ["desvirtuamento, sem querer, do que eu disse”] dá mesmo sensação de ter começado antes, ser aquilo que a gente tomou como início, uma continuação. Experimente você arranjar um começo nesse caso, e verá ser impossível, apesar da 
nossa sensibilidade continuar sentindo o contrário. Quem sabe se o tema começou antes no subconsciente!?... Casos assim em todos os compositores é possível a gente encontrar. Outro dia, conversando com o Frutuoso Vianna, nós comentávamos isso mesmo, que muitas vezes um começo não e bem um começo, parece mais uma continuação. Gostaria que você me respondesse: quando é que um tema é inicial e o que é necessário para sê-lo?

Você encontrou sétima abaixada, síncopa no tema ${ }^{5}$. Pois eu nem pensei nisso. Quem sabe? Se eu vivesse na China ou no Japão não os teria usado!... Se de fato uso sempre isso a justificação é a esta: a inspiração é um fenômeno subconsci- ente e involuntário, por conseguinte, deve ter alguma relação com o meio em que a gente vive! Depois dessa afirmativa, você pode pensar: não se controla mesmo, te-nho razão de afirmar isso; sofre suficiência de si mesmo. Mas meu caro, de acordo com Ribot: 'o trabalho criador é também organizador, cria e coordena ao mesmo tempo; é o trabalho crítico que acrescenta, elimina, adapta $e$ modifica'. Fique sabendo que para a Sonata chegar a ser uma realidade, ela sofreu toda expurgação possível e (concordando com você) ao passar a limpo novos retoques os quais só terminarão quando ela já estiver impressa e quem sabe se na reimpressão ainda sofrerá outras modificações. Se com tudo isso você continuar achando que eu não me controlo, é porque estou fazendo alguma coisa que você ainda não percebeu. Como pode ser boa, pode ser má. Você não sabe a quantidade enorme de trabalhos que eu tenho inutilizado! Se fosse como diz você, eu estaria convicto do valor que eles pudessem ter, e assim estariam eles fazendo parte da minha obra. Quem sabe se a minha autocrítica ainda não está bastante desenvolvida e nesse caso dou a minha mão à palmatória!... O que eu não posso compreender é você dizer que estou falsificando intelectualmente a invenção. Os fenômenos que eu sinto, só a inspiração os justifica e logo após, (no momento de escrever) a criação artística. Você mesmo já disse: 'a criação artística é preliminarmente um desafogo. Como todo desafogo ela importa preliminarmente pro indivíduo e necessariamente deriva e se organiza daquilo que o indivíduo tem de só dele.' Não Concordo com essa substituição da invenção, por 'falsificação da invenção'. Talvez no dia em que você ouvir a sonata num comcerto ela provoque um estado de alma no qual você acabe achando afinal que os meus desenvolvimentos não se 'justificam apenas tecnicamente'... Sentirá nesse caso que obedeceram a uma lógica interior.

Apesar de achar você que ela não é uma página substancial, eu confesso estar em desacordo, porque penso que esse meu trabalho ocupa um lugar importante na

5 O abuso de síncopas e sétimas abaixadas se enquadram no que o musicólogo chama no Ensaio de "brasileirismo"; não passariam de clichês. 
minha obra e acho mesmo que representa um período de transição e libertação de muitos cacoetes que aparecem nas minhas obras anteriores,

Você se engana em pensar que uso a dissonância pela dissonância, por ser moda, afinal! (...) a razão pela qual elas foram usadas é de ordem puramente expressiva. (...) As que estão na minha sonata devem ser executadas em pp porque estão em $3^{\circ}$ plano sonoro. Têm função de ambiente. Eu queria um [efeito] que não se definisse bem, que ficasse meio no ar, e ficou... Se você não sentiu isso, talvez fosse por falta de disposição da sua parte, o que é uma coisa muito possível...

Sei que o seu tempo vale ouro, não quero roubá-lo mais, por isso paro por aqui. Na próxima confissão (!) farei o possível para explicar o meu abuso modulatório (no seu dizer) e as minhas ideias sobre o muito discutido atonalismo"

(idem:209-212).

O principal ponto de discordância parece residir na caracterização do trabalho de criação, isto é, a delimitação do que é da ordem do indivíduo, e o que é da ordem do social. Mário parece se apegar à dimensão coletiva da obra, da elaboração artística consciente, mediada pela razão histórica sobre o material da qual é fruto, enquanto Guarnieri alude a possíveis entrelaçamentos insondáveis entre subconsciente, inspiração e a mediação do cultural nesses níveis aparentemente individuais, prevendo certo "espontaneísmo" da criação, num primeiro momento acima de escolhas procedimentais plenamente racionalizadas, que tomaria forma à medida que o material apresentasse caminhos de desenvolvimento. Os grifos e comentários que o primeiro faz na carta da réplica chamam a atenção para o que o preocupava no modelo de criação depreendido da resposta, não tão distante assim do horizonte individualista, do apelo a clichês e exotismos, ao qual circunscreveu Villa-Lobos no Ensaio. Em certos momentos da carta do compositor se tem a impressão de que assume com certa rebeldia a adoção de procedimentos à revelia do que lhe foi orientado, concluindo o conteúdo da missiva no tom sarcástico da afirmação de que estaria se "confessando", tendo que se “justificar" perante uma "autoridade".

O compositor progressivamente durante a década de 30 se dá conta de outras alternativas de viabilização de carreira e incremento de formação. À medida em que o domínio como compositor restrito ao piano, por conta da familiaridade e da facilidade em ver os resultados sonoros da partitura, expande-se a partir de 1935 com a prática da escrita orquestral, auferida do acesso a conjuntos maiores proporcionado pelas incumbências da colaboração com o Departamento de Cultura, novas possibilidades surgem. Principalmente a alternativa de se consagrar nacional e internacionalmente através da experiência como bolsista na Europa, empreendida com êxito por outros compositores modernistas, e por lá aprimorar sua técnica e escrita sinfônica. Com isso, engaja-se em novas parcerias com outros agentes, para além de Mário de Andrade, da efêmera 
gestão do Departamento de Cultura e de sua rede de apoiadores em São Paulo. Assim, a estadia em Paris se daria ainda graças às relações no Departamento e no CDMSP; já a viagem aos Estados Unidos, no início dos anos 1940, seria arranjada por meio do apoio de Luiz Heitor, espécie de embaixador da música brasileira na Europa e nos Estado Unidos e do contato com Curt Lange, espécie de mediador de uma enorme rede de compositores na América Latina, contato intermediado por Lamberto Baldi no Uruguai.

Após ser "selecionado" via Conselho de Orientação Artística em um conturbado processo que escolheria um bolsista laureado pelo Prêmio de Aperfeiçoamento Artístico, Guanieri ruma à Paris com suas novas esposa e sogra. Flávio Silva em "Invitation au voyage" conta que os membros da banca de seleção eram seus amigos do CDMSP e apoiadores; entre eles Samuel Araújo, Mozart Tavares de Lima, Agostino Cantù e Mário de Andrade. Segundo Silva, este último ainda cumpriria um papel importante à concretização da viagem ao conseguir junto à prefeitura a manutenção do salário do Departamento, sob pretexto do aperfeiçoamento da regência do Coral Paulistano (cf. SILVA, 2001:73). Uma vez em Paris, em julho de 1938, a despeito de vários problemas e insegurança quanto ao financiamento da empreitada pela nova gestão municipal, que demitira Mário de Andrade do cargo de diretor, procura Charles Koechlin para continuar seus estudos de composição. Guarnieri deve ter tomado conhecimento de Koechlin a partir de algumas obras teóricas do francês constantes na biblioteca pessoal de Mário de Andrade, e da apresentação de uma peça deste cantada por Lavínia Viotti, primeira mulher de Guarnieri. O novo professor, tendo estudado no Conservatório de Paris, era adepto de uma pedagogia mais aberta e flexível, e preocupava-se em ensinar aos alunos uma ampla gama de procedimentos ligados às experiências contemporâneas da música europeia, sempre explicando suas razões de ser, seus porquês - apanágio que o aproximaria do estilo pedagógico de Baldi. Aliás, havia concepções de música comuns a Mário de Andrade e Koechlin, pois este era igualmente estudioso de folclore e se interessava pelo caráter socializante da música. A compatibilidade de ideias talvez tenha valido a indicação da leitura dos livros de Koechlin ao jovem compositor ávido por continuar a formação interrompida com Baldi.

Segundo o historiador André Egg, Guarnieri teria aprendido muito mais com a observação dos tantos concertos que frequentou em Paris do que propriamente com as poucas aulas com Koechlin, porquanto a quantidade reduzida de encontros com o professor e as dificuldades financeiras para se estabelecer com conforto na capital francesa obrigaram-no a buscar caminhos mais imediatos de interação com o meio musical francês (cf. EGG, 2010:97-106). Da correspondência com o professor, entrevê-se as atribulações do bolsista, às voltas com relatórios e as tentativas de auferir audições de suas peças, em meio ao crescente clima de tensão que acometia 
a França instantes antes da eclosão da Segunda Guerra Mundial. As apresentações que logra realizar em Paris, apesar de poucas, causam boas impressões em Koechlin, que passa a se interessar por Guarnieri e a tratá-lo como amigo, cessando a cobrança de exercícios de composição:

“O estilo das cartas muda muito a partir da carta de 19 de fevereiro de 1939. Nesta, Koechlin indica a impressão muito favorável que teve ao assistir a um concerto com obras do compositor brasileiro, informando que escreveu uma crítica entusiasta para o jornal Le jour. (...) sabemos que houve um concerto na Sale Pleyel, em 12 de fevereiro. Teve entre as obras executadas o ciclo Três poemas para voz e orquestra, em transcrição para voz e piano. A obra foi composta (na versão original e na transcrição) neste mesmo mês de fevereiro. A execução foi com a cantora Cristina Maristany e o compositor ao piano. Sabemos também de outro concerto promovido no auditório da Révue Musicale em 7 de fevereiro, no qual foi executada a canção Vai azulão, composta em janeiro deste ano. (...) Entre 19 de fevereiro e 29 de maio o francês escreveu mais 8 cartas, que se tornam mais longas, mais pessoais. A partir de meados de março, não há mais indícios de envio de exercícios” (idem:100)

Assim, a estadia em Paris rende ao compositor uma pequena rede de contatos, dos quais a amizade com Koechlin o levaria a constar em algumas revistas de crítica musical francesas. A partir de indicação deste, Guarnieri estuda regência com François Rühlmann, da Ópera de Paris; Koechlin também o auxilia na adaptação à cidade e o apresenta a várias pessoas que lhe seriam de grande ajuda na divulgação de sua música por lá. Neste sentido, Andrée d'Otemar, professora de canto de sua esposa, cumpre igualmente o papel de lhe apresentar a personalidades da música francesa. Quanto à influência musical, é possível constatar a acuidade técnica e atenção à estrutura das grandes formas, estimuladas nas preleções do professor em seus livros - a exemplo, o manual de fuga em que Koechlin faz a defesa do estudo da fuga estrita para, gradualmente compor fugas livres, mais abertas. No entanto, os breves estudos com o compositor francês foram duradouros para a personalidade de compositor, pois os críticos modernistas se valeriam do discurso do "maestria e rigor no trabalho com as grandes formas" para lhe conferir um atributo de exclusividade, de identidade artística, e assim distinguir Guarnieri dos outros compositores.

A experiência na França foi significativa para o amadurecimento do compositor, que pôde ouvir um amplo repertório, antes parcialmente conhecido em partituras e gravações. A qualidade das execuções e o alto nível dos conjuntos e intérpretes o instigariam a adotar altos padrões de qualidade, esforçando-se para alcançá-los em suas performances e produções. Ademais, as audições de suas peças, apesar do baixo número, foram bem recebidas pelo público local. Ao final de 1939, Guarnieri retornaria ao Brasil, forçado não só pela guerra, mas talvez mais ainda pelo corte de seu salário municipal, acumulado à bolsa. Fora demitido do cargo de regente do Coral Paulistano pela 
nova gestão de Prestes Maia, que encarregara Frutuoso Viana do serviço.

A situação em São Paulo não lhe era, pois, tão favorável como antes. As reviravoltas políticas do meio com o qual estava acostumado interrompia sua ascendência e os planos de internacionalização, inflexão que deixaria o compositor em vias de se consagrar ressentido com o campo musical paulista; soma-se às dificuldades do retorno a desilusão de seu orientador modernista, que passa a duvidar da viabilidade do projeto modernista e se muda em 1940 para o Rio de Janeiro, amargando posições inferiores a fim de participar de outras iniciativas. Sobre seu projeto à frente do Departamento de Cultura, Mário afirma:

"Sacrifiquei por completo três anos de minha vida começada tarde, dirigindo o

D.C... Digo por completo porque não consegui fazer a única coisa que, em minha consciência, justificaria o sacrifício: não consegui impor e normalizar o D.C. na vida paulistana." (ANDRADE apud OLIVEIRA, 2005:12).

Com isso, conclui-se que, apesar de o nacionalismo modernista ter se tornado a "estética" de maior legitimidade no campo musical, domínio visto na produção dos principais compositores brasileiros, seus representantes não lograram construir instituições musicais relativamente independentes dos círculos de poder do Estado, nem políticas públicas de ampliação do meio, redundando na continuidade das limitações de antes. $\mathrm{O}$ fato de Guarnieri, tido como o principal compositor modernista em São Paulo não ter se formado em instituições locais, nem ter conquistados colocações profissionais estáveis é sintomático desse fracasso parcial.

No início da década de 1940, com efeito, era perceptível o mesmo tipo de ressentimento de Mário de Andrade em Guarnieri, que não queria ter de se ver em condições rebaixadas em relação as que auferira nos cargos de importância junto ao Departamento de Cultura; a possibilidade de estar à frente das poucas instituições de difusão de repertório públicas e poder ouvir e apresentar suas peças, nem deixar de colher as láureas que aguardava receber na volta de Paris ao meio musical paulista, almejando o reconhecimento de integrar o seleto grupo de compositores contemporâneos consagrados internacionalmente. Assim, a situação demandava o ativamento do capital social acumulado durante a década de 1930 para prospecção de novos caminhos - e meios musicais - acrescida da percepção de que não deveria somente se ater a intelectuais, porquanto já havia boa fortuna crítica a seu respeito. Deveria procurar relações com editoras, intérpretes influentes, empresários interessados em música de concerto e demais agentes capazes de fazer com que sua obra ganhasse os palcos. Volta-se para colaborações e parcerias com diversos e variados apoiadores do Rio de Janeiro, de Porto Alegre, estrangeiros, etc. Em São Paulo, chega a se 
aproximar do grupo de vanguarda que combateria energicamente na década de 1950, o Música $\mathrm{Viva}^{6}$, em franca ascendência no cenário musical nacional, publicando uma elogiosa primeira "carta aberta” (1941) acerca da peça Música de câmara de Koellreutter. Neste artigo, publicado na revista Resenha Musical, Guarnieri mostra interesse, com reservas, pelas produções atonais num tom bastante diplomático ao tratar da querela, sentenciando quase ao final que "Todos os meios são lícitos quando visam um fim puramente artístico, sincero"; conclui com "Receba um abraço do seu amigo". A boa vontade para com a peça pode ter parte com certo interesse em partilhar das oportunidades que o ascendente grupo lograva cavar no restrito espaço da música. É fato que Guarnieri compõe o Improviso $n^{\circ} 1$ para flauta solo dedicada a Koellreutter (que era flautista), interpretado pelo músico alemão em concerto no qual os dois apresentaram músicas de Hindemith, Bach e Schubert no Teatro Municipal de São Paulo, em novembro de 1941. Ademais, a boa vontade se deve igualmente ao progressivo afastamento das orientações de Mário de Andrade e à vivência das correntes modernistas estrangeiras da recente estadia na França, donde apreende outros critérios de classificação para significar suas obras.

As "contradições" que acompanham toda a trajetória de Guarnieri quanto ao emprego das dissonâncias num registro "atualizado", foram provavelmente gestadas pelos diferentes quadros de referências e representações de modernidade circunscritos aos círculos de sociabilidade nos quais o compositor se movimentou, embora sempre estivesse mais próximo daqueles vinculados ao Estado e menos dos que se vinculavam ao PCB. Os pré-requisitos para se atestar a modernidade das obras eram conflitantes entre os círculos modernistas, e uma sismografia de seus atritos, bem como os desenlaces materiais de realização de seus projetos ao longo dos tempos não deixaria de elucidar as alterações e inflexões nos respectivos conjuntos de representações plasmadoras dos critérios de classificação de modernidade. Se, por um lado, Mário de Andrade e seu círculo mais próximo antes e durante a gestão do Departamento não viam sob bons auspícios para o projeto de brasilidade as propostas de depuração do material (folclórico) que as vanguardas europeias inspiravam em Guarnieri, por outro, o compositor, para se formar e consagrar, realiza experiências de maturação técnico-estéticas em outros círculos modernistas, centralizados por músicos imigrantes com outro aporte de questões culturais e estéticas. Assim sua produção podia tanto conter os aspectos do projeto de brasilidade que tornaria Guarnieri apreciado nos círculos nacionais mais próximos ao Estado, quanto o brio do atonalismo livre, o qual lhe interessou adotar em vários momentos de sua trajetória artística, a fim de ser apreciado nacional e internacionalmente.

Mas sua volta ao Brasil, em meados de 1940, acompanha o deslocamento das alianças do

6 Exploraremos as relações entre Guarnieri e o Música Viva no último capítulo, ao tratar do surgimento de um sistema de rivalidades meio musical erudito até então hegemonizado pelos compositores da geração modernista. 
modernismo paulista para o Rio de Janeiro, especificamente para o Ministério de Gustavo Capanema. Lá, seu principal apoiador era Luiz Heitor Correa de Azevedo, que já cumpria bem esse papel na crítica carioca, em revistas que dirigia, e conseguindo concertos para o paulista. Luiz Heitor exerceu uma miríade de atividades relacionadas à música, boa parte delas proporcionadas pelas boas relações com o varguismo, a ligação com Luciano Gallet na Associação Brasileira de Música, bem como no Instituto Nacional de Música, e com os círculos paulistas do modernismo:

"Ativista de um órgão associativo (Associação Brasileira de Música) e editor de sua revista; daí convidado a bibliotecário da principal instituição de ensino musical (Instituto Nacional de Música); editor da principal revista de música já publicada no país (Revista Brasileira de Música); professor catedrático da mesma instituição, agora alçada à condição de departamento universitário; responsável pela música erudita nos órgão oficiais do Estado Novo (Revista Cultura Política e programa radiofônico 'Hora do Brasil')”. (EGG, 2010: 136)

Assim como Guarnieri, tanto conhecia as dificuldades do meio musical, quanto, mas em maior grau, movimentava-se em diferentes espaços e constituiu uma extensa rede de contatos, entre críticos, professores de música, musicólogos, compositores, intérpretes e editores, brasileiros e estrangeiros. Assim, mesmo sendo um dos principais intelectuais do meio musical, tendo praticamente livre trânsito no âmbito do poder político do Estado, torna-se uma espécie de embaixador da música brasileira nas temporadas que passou em Washington, a serviço da Pan American Union, e em Paris, onde exerceu um cargo na UNESCO.

Luiz Heitor ocupou a representação brasileira na seção de música da União Pan-Americana por ter chamado a atenção da Biblioteca do Congresso (Library of Congress) quanto à metodologia e qualidade dos trabalhos à frente de um projeto de gravações de músicas regionais brasileiras, organizadas em uma coleção de discos; em função do intercâmbio estabelecido, a instituição recebeu em seu acervo cópias dos discos. A linha dessas instituições norte-americanas ligadas à música de promover tais intercâmbios provinha de profissionais reputados da área, membros do comitê setorial de música do OCIAA (Office for Emergency Management Coordinator of InterAmerican Affairs), agência conjunta ao Departamento de Estado e criada por decreto presidencial em meados de 1940 no contexto da entrada dos Estado Unidos na Segunda Guerra Mundial.

As atividades musicais do OCIAA datam do ano 1940, quando se expediram vários relatórios encaminhados ao referido Comitê de Música com dados e análises da dimensão da propaganda nazista e fascista veiculada nas emissoras de rádio latino-americanas. Os documentos apontavam a representação negativa dos Estados Unidos pela propaganda inimiga, especialmente no que concernia à direção política, alardeada como autoritária e dirigista, e às formas de vida dos 
norte-americanos. No cenário de uma vitória da Alemanha na guerra, temia-se a interferência do Eixo por meio do controle econômico, ou até de uma invasão direta, em um território fundamental aos interesses comerciais dos Estados Unidos. O Estado norte-americano tinha, portanto, como imprescindível a participação das empresas no planejamento de uma estratégia contraofensiva de propaganda, porquanto os efeitos negativos de uma possível intervenção alemã na América Latina lhes seria diretamente prejudicial. Assim, um dos primeiros passos era aperfeiçoar a qualidade da transmissão das rádios em ondas curtas e financiar programas em emissoras locais (cf. TACUCHIAN, 1998:86). Os comitês setoriais, formados por especialistas e profissionais reconhecidos nas áreas, deviam não só recolher mais informações sobre a situação dos vários meios musicais dos principais países do continente ao Sul, como propor soluções através de propostas que se coligiram num verdadeiro programa musical de caráter bilateral, prevendo o intercâmbio entre agentes dos dois campos, interessados em formação, pedagogia do ensino de música, pesquisa de materiais folclóricos, etc. Além dos especialistas representantes dos segmentos da vida cultural, o Departamento de Estado contava com a participação de empresas e instituições civis:

“(...) Na área de cinema e rádio, como Columbia Broadcasting System, fundações culturais, como Guggenheim Foudation, Carnegie Foundation e The American Council of Learned Societies, universidades e escolas isoladas, como Northwestern University, University of Michigan e Berkshire Music Center, entidade ligada a Orquestra Sinfônica de Boston. A área de educação musical estava representada pela Music Educators National Conference e Music Teachers National Association” (idem: 87)

Afora as citadas, empresas mais ligadas ao filão da música erudita participaram do programa, como editoras, gravadoras e fundações de orquestras da extensa rede criada no final do XIX de conjuntos, conservatórios e salas de concerto das capitais de praticamente todos os estados dos Estados Unidos. Houve bastante interesse por parte dessas instituições de participar desse e de outros programas do governo em 1940 por conta de um problema comum ao meio musical brasileiro da década de 1920, qual seja, o privilégio comercial dado à difusão da música europeia em detrimento do estímulo à produção nacional - atinada com questões de material folclórico e criação de uma autenticidade nacional, assim como os modernistas brasileiros.

O Comitê de Música era consultivo e suas propostas eram levadas à apreciação de uma esfera superior, o Executive Commmittee, onde também eram avaliados os projetos da Divisão de Música da Pan-American Union (PAU), que tinha por diretor Charles Seeger. As duas instâncias compartilhavam funções similares quanto à elaboração de programas de intercâmbio artístico e serviam ambas a estratégias de influência cultural de territórios; a diferença estava os vínculos 
mais diretos do OCIAA ao Departamento de Estado, o que fazia de seu Comitê de Música um espaço de articulação de interesses políticos, comerciais e artísticos mais centralizado pelas diretrizes do Estado, enquanto à Divisão de Música da PAU cabia formular programas de intercâmbio de modo mais diplomático, conjuntamente aos representantes culturais dos países latinos. Essa tênue diferença, apesar de inexistir por vezes na prática, visto que Seeger se tornou "membro consultor" do já consultivo Comitê, parece ter propagado uma curiosa maior aceitação da PAU, relativamente à OCIAA e seus agentes, vistos por setores dos países visados com desconfiança por conta do elo com o Departamento de Estado e as circunstâncias táticas de sua instauração pela Presidência. Não à toa Carleton Sprague Smith e Aaron Copland realizaram viagens ao Brasil sob incumbências do Comitê valendo-se, respectivamente, de seu cargo na New York Public Library e de sua posição de presidente da American Composers Alliance, enquanto Seeger se apresentava como membro da PAU. O esforço de apagar a proveniência dos recursos e o caráter de formulação do OCIAA, era empreendido por meio da ativação de outras instituições culturais:

"Para o ano fiscal de 1941-42, Rockfeller [Coordenador geral do Office] alocou para a área de música, US\$100.000 para serem utilizados como apoio financeiro aos projetos programados. (...) O orçamento incluía o repasse de verbas para o Centro de Música da PAU (US\$15.000) para pequenos projetos. O Coordenador tinha especial interesse em repassar os recursos para que os projetos saíssem com a chancela daquele organismo panamericano, evitando assim o envolvimento do nome do OCIAA. Este estava sob permanente acusação de ação propagandista na América Latina, notadamente pela imprensa local. O coordenador manifestava preocupação de que as atividades programadas aparecessem sob a sigla National Defense, esfera à qual sua Agência estava subordinada”.

E sobre o investimento, especifica:

“A soma referia-se a projetos relativos à pesquisa de campo na área de educação musical, intercâmbio com a Discoteca Pública de São Paulo, referente à cópia do acervo de material sobre folclore, organização de uma bibliografia de livros de música e material de referência, pesquisa de campo sobre o carnaval no Brasil e outros países da América Latina, turnês de companhias de balé, coral e quinteto de sopros, (...) programa de intercâmbio de estudantes, etc.” (idem:91)

Os principais mediadores do panamericanismo no Brasil foram Carleton Sprague Smith, Charles Seeger e Aaron Copland, já citados. Todos fizeram muitas viagens aos países da América do Sul, sendo o primeiro e o terceiro encarregados pelo OCIAA/Departamento de Estado de compor um detalhado relatório sobre a vida musical de alguns países, a fim de estabelecer conexões e 
conhecer as condições para possíveis intercâmbios. O OCIAA cobrava uma relação padrão de informações e tarefas que deveriam constar no relatório:

"1 - Verificar as principais coleções, arquivos musicais e conservatórios da América Latina (área de interesse de musicólogos e educadores); 2 - Levantar a demanda de pesquisa e condições de sua realização (instituições especializadas na área); 3 Examinar métodos e programas de educação musical; 4 - Contatar associações musicais, os principais compositores e identificar 'pessoas-chave' para o intercâmbio; 5 - Verificar a disponibilidade e condições físicas de salas de concerto; 6 Empreender uma classificação da música folclórica latinoamericana; 7 - Examinar as possibilidades de oferecimento de bolsas de estudo e apoio financeiro a estudantes, musicólogos e intérpretes norte-americanos em viajar à América Latina” (idem: 113)

Reunir tantas informações e contatos em alguns meses de viagem se revelou extremamente difícil em relação ao Brasil, sobretudo pela falta de tradição de pesquisa em música, fato que os impediam de se amparar em dados estatísticos e estudos históricos de música do país. Assim, Smith e outros, concentraram-se em travar relações com as figuras chaves da música e reportar o que podiam conhecer do campo musical através de observação própria e das conversas com essas figuras. Do conhecimento das condições do meio musical do Brasil, bem como do empenho em estabelecer uma rede de agentes do campo musical brasileiro, Smith pôde perceber o destaque de Camargo Guarnieri, Mignone e Villa-Lobos na área de composição. Os três seriam os principais beneficiados e envolvidos em ações da PAU e em parcerias com orquestras, escolas de música e editoras norte-americanas, mas foram escolhidos por diferentes motivos. Mignone dispunha de boas oportunidades junto ao Estado Novo, em cargos como professor do INM e diretor do Teatro Municipal do Rio de Janeiro, e era visto como uma influência a ser conquistada e "neutralizada" pelo panamericanismo, uma vez que fora convidado pelo governo alemão a passar duas temporadas em Berlim (1937 e 1938) como regente, no que teve a oportunidade de executar peças próprias.Villa-Lobos estava muito bem acomodado no Estado Novo, pois supria sozinho toda a demanda de música para o sistema educacional do país, compondo por conta todo o material do Guia Prático - conjunto de hinos patrióticos e canções infantis arranjadas para piano, coral e piano e voz. Villa-Lobos iria se aproximar das oportunidades de colaboração com a PAU somente depois de 1945, após o término de suas atribulações no Estado Novo. Guarnieri, dentre os três o menos atendido pelo varguismo, beneficiou-se mais das políticas de "boa vizinhança" para as artes. O contraste entre seu reconhecimento artístico na crítica e as perspectivas profissionais pouco auspiciosas no Brasil contribuíram para o investimento na carreira internacional, necessária à 
consagração como compositor e à superação dos obstáculos da profissionalização e das dificuldades financeiras.

Em cartas trocadas às vésperas da ida a Washington, Luiz Heitor pede ao amigo paulista que enviasse partituras de peças autorais para que fossem avaliadas e, talvez, executadas. Como membro brasileiro da PAU, Luiz Heitor se encarregaria da tarefa de divulgar o nome de Guarnieri entre os outros membros. É por sua recomendação e intermédio que Guarnieri desperta a atenção de Sprague Smith, Seeger e Copland, passando a se corresponder com os três representantes da PAU e da OCIAA antes mesmo das apresentações pessoais. Os três agentes se tornam, assim como Luiz Heitor no Rio de Janeiro, apoiadores centrais de sua rede nos EUA. Em outra carta de Luiz Heitor ao compositor é dada a notícia do arranjo da primeira de várias viagens que Guarnieri efetuaria ao longo da década de 1940 ao país de seus novos apoiadores, especificando que, novamente, tivesse às mãos peças escritas para apresentar a editoras, trazendo-as consigo. Enquanto convidado da PAU e livre de despesas, Guarnieri atenderia a visitas a escolas de música, com a finalidade de conhecer o sistema de ensino musical. Mas, ao que parece pelo tom da carta, tratava-se de cristalizar colaborações com "trunfos de primeira categoria", expressão usada por Luiz Heitor ao se referir a Aaron Copland.

Dos rendimentos da primeira viagem aos EUA, em 1942, contam-se edições de partituras, concertos e até algumas encomendas de obras, além da conversão dos contatos com Smith, Seeger e Copland em amizades pessoais. Em contrapartida, Guarnieri se empenharia em difundir as produções do modernismo norte-americano no Brasil, regendo peças de Copland.

Não só o contexto geopolítico de 1940 contaria à colaboração, mas também as políticas rooseveltianas voltadas para a superação da crise da Grande Depressão dos anos de 1930. Por meio de medidas em parceria com fundações privadas e empresas comerciais do ramo que previam a criação de empregos e expansão de mercados, o "Projeto Federal para a Música" ( Federal Music Project) seria implementado, isto é, a construção e financiamento de uma ampla estrutura nacional de conjuntos musicais, sistema escolar de formação musical, fomento editorial, circuito de concertos, transmissões radiofônicas e gravação de discos. Tais políticas alargam o horizonte de possibilidades de Guarnieri, cuja inserção no meio musical estrangeiro atende à demanda por criação de música de concerto do mercado local, ao mesmo tempo que finalmente lhe confere o alcance mundial, pretendido na frustrante estadia parisiense. Os latino-americanos não eram os únicos a se beneficiarem, como toda uma geração de músicos norte-americanos que competiam em seu próprio país com a música europeia difundida pelas instituições musicais; careciam de oportunidades no c ircuito de concertos e no mercado editorial, voltado a compositores já consagrados, tendo que viver dos rendimentos auferidos no m ercado da música popular e de 
divertimento. Portanto, a colaboração entre intelectuais e artistas brasileiros e norte-americanos não expressava somente uma política de Estado, mas também um movimento de confluência de interesse desses mesmo agentes que passavam por limitações parecidas em seus respectivos meios. Em ambos os casos é nítido o pr otagonismo dos músicos e intelectuais em projetos de desenvolvimento do campo musical. 


\section{CAPÍTULO 3}

\section{Modernidades em busca de uma tradição}

A extrema dificuldade em ter suas músicas executadas, movimentação nos espaços do Partido Comunista Brasileiro e uma orientação mais ou menos próxima ao nacionalismo, corrente estética hegemônica da década de 1950, são características comuns aos três principais compositores do grupo Música Nova no começo de suas trajetórias. O nacionalismo vigorava em todos os círculos do meio musical, portanto inspirava diretrizes de ensino em vários conservatórios e instituições musicais que se alinhavam tanto ao PCB, quanto à Academia Brasileira de Música cuja formação em 1945 demonstra a força política da estética nacionalista associada às relações de seu presidente, Villa-Lobos, e alguns membros cariocas, ao Estado; a despeito da presença de Cláudio Santoro e outros membros, nem tão alinhados àquela estética, nem ao governo de Getúlio Vargas. Para compreender a adesão ao nacionalismo, há o caso comentado por Márcio Bezerra da "Sonatina à la Mozart” (1953) de Gilberto Mendes, uma de suas primeiras composições. Trata-se de uma paródia à brasileira da "Sonata em Dó maior" K545 de Mozart. Na peça de Mendes, a sobreposição da forma-sonata com trejeitos "típicos" brasileiros - como síncopas, empregadas de maneira excessiva - resulta em uma reinterpretação irônica da peça de Mozart. Segundo o compositor, a ideia da paródia surgiu após ouvir "Bach goes to town", releitura jazzística de Bach feita por Benny Goodman (cf. SOUZA, 2011:). O pastiche, procedimento que não era comum na música erudita brasileira daquele momento, não foi muito bem recebido pelos poucos colegas de Mendes do Conservatório de Santos. Até 1953 permaneceu sem nenhum tipo de reconhecimento e se declarava "autodidata", não se adequando nem aos ditames de Guarnieri, nem aos de Koellreutter. Nestas condições não conseguia com que suas músicas fossem executadas - a maioria acabava indo para a gaveta. A pressão para se posicionar e aderir a uma das correntes estéticas da época aumentou. Neste ponto, sua movimentação no círculo de sociabilidade do PCB foi fundamental no que se refere à reorientação de sua postura estético-musical. Gastão, seu amigo artista plástico e filiado, aconselha-o a mostrar suas músicas à colega de partido e consagrada pianista, Ana Stela Schic. Em trecho de entrevista, Mendes diz:

“Aí, quando entrei para o PCB, levei todas as minhas músicas para uma pianista: Ana Stela Schic. Te contei? Ela foi uma grande pianista brasileira e gravou a obra integral de Villa-Lobos; ela foi a primeira que fez isso (...). A Ana Stela Schic era do Partido Comunista (...). Eu era o mais ilustre desconhecido possível, mas ela aceitou, pois era um pedido de um correligionário (risos). Eu fui com o Gastão, conversei e deixei minhas peças com ela. Aliás, deixei naquela altura tudo o que eu tinha 
composto, na verdade (...). Mas ela primeiro demorou muito para chamar a gente de volta, e quando nós voltamos lá, ela meteu o pau em tudo. Achava que era tudo muito cosmopolita, que não tinha nada de Brasil. Ela era comunista e o partido estava nessa. (...) Ela fez uma crítica muito negativa, muito ideológica (...). Eu resolvi fazer música brasileira depois da porrada que eu levei da Ana Stela Schic, o que eu não diria que foi horrível porque eu tenho jeito para música popular também” (fala de Gilberto Mendes, gravada em 21/12/2009 em entrevista à Carla Delgado).

A pianista, assim como boa parte do PCB, estava alinhada às diretrizes de Andrei Zhdanov, nomeado por Stálin para a dirigir a política cultural da União Soviética. A partir do momento que Gilberto Mendes se vinculou, de certa forma, à proposta nacionalista pela via pecebista sua produção começou a ser melhor recebida pelos intérpretes com quem tinha contato, o que viabilizou a execução de algumas músicas pela primeira vez. Seus contatos no partido contribuíram mais ainda para sua formação musical: de 1953 a 1959, tem aulas de composição com Cláudio Santoro. No entanto, na contramão de grande parte dos compositores nacionalistas, nutria maior interesse pela estrutura modal e rítmica do material oriundo do folclore; interessou-se mais pela música popular urbana que ouvia em Santos do que pelo material colhido por Mário de Andrade e afirmava que não lhe instigava a mente fazer arranjos e harmonizações de melodias folclóricas - a exemplo do que Guarnieri, adepto da forma-canção, realizava. Willy Corrêa de Oliveira ainda não estava organicamente vinculado ao $\mathrm{PCB}$, mesmo já o frequentando e se declarando comunista na metade da década de 1950, em razão de crises com o protestantismo familiar. Sobre sua produção, Maurício de Bonis afirma:

“O levantamento das obras desse primeiro período da produção de Willy, até cerca dos 22 anos, consistiria hoje em garimpo musicológico dos mais árduos. Com algumas exceções, as peças dessa época foram destruídas pelo compositor quando de sua aproximação da música de vanguarda, tal a transformação em seu universo referencial” (BONIS, 2012:187).

Contudo, já havia registros de embates internos em torno do zhdanovismo no partido; o mais famoso deles, como vimos, foi o episódio da Carta Aberta aos músicos e críticos do Brasil. Nela, M.C. Guarnieri combate a estética "universalista" da vanguarda que ganhava espaço na cena musical da década de 1940 por meio do movimento Música Viva, formado em torno de HansJoachin Koellreutter. Guarnieri articula seu texto defendendo certa correspondência entre as ideias de Mário de Andrade (contidas em seu Ensaio sobre a música brasileira) e a fala de Andrei Zhdanov no II Congresso Internacional dos Compositores e Críticos de Música de Praga, em 1948. 
Há relatos que atribuem a autoria da "Carta Aberta" ao irmão do compositor, o poeta Rossini Camargo Guarnieri, conforme comentários à ép oca de Pagu, Rogério Duprat e outros (ZERON, 1991:33). Para Duprat, militante bastante atuante da ala crítica ao stalinismo e dirigente da seção do partido em Brasília em 1965,

\section{“A 'Carta Aberta aos músicos e críticos do Brasil' não foi o Camargo}

Guarnieri que escreveu, pois ele não era capaz de escrever nem o primeiro parágrafo (...). A 'Carta Aberta' foi uma resposta ao 'Manifesto Música Viva' de Koellreutter (...). Na ocasião da discussão do manifesto do Koellreutter, no Museu de Arte, na rua Sete de Abril, estávamos todos lá: nós [Damiano Cozzella e Décio Pignatari], o Oswald [de Andrade] e o pessoal stalinista bravo do partido, que gerou a 'Carta Aberta'. Nós estávamos ali como membros do partido e estávamos mesmo fazendo divisionismo dentro do partido" (citação tirada de sua entrevista "Descobrimos o fim da música" apud ZERON, 1991:46).

O zhdanovismo permanece como orientação vigente no período dos compositores do Música Nova e dos concretistas, que tiveram até então a liderança de Jorge Amado no seu setor cultural, quando lá colocam suas propostas de política cultural, alternativas à linha do Comitê Central - aquelas

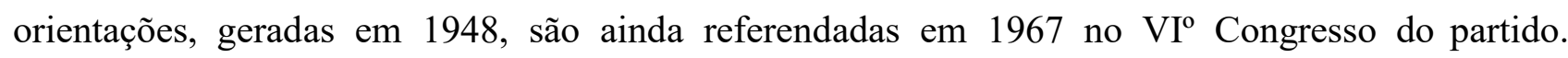
Pelo depoimento de Duprat, percebe-se o conflito entre gerações que se instaura no PCB:

"Foi uma briga antistalinista dentro do partido. Em 52 - 53 começou a briga da nova geração, que era a minha, contra o stalinismo lá dentro. Pau a pau, fomos nessa briga por 10 anos. O stalinismo, se você quer saber, era representado por um sujeito chamado Jorge Amado. Era o maior stalinista do Partidão, um cara que queríamos ver morto, um safado, no sentido de que usava todos os artifícios que qualquer safado usa hoje no governo Figueiredo" ("Descobrimos o fim da música" op. cit.).

Ao final dos anos 50, Willy e Gilberto se conhecem em Santos em função de frequentarem os mesmos espaços e terem afinidades artísticas e políticas (o PCB). Começam a estudar composição com George Olivier Toni, que os apresenta a Rogério Duprat, o qual na época não tinha mais aulas com Toni e trabalhava como violoncelista nas orquestras de televisão e rádio (Tupi, Rádio Nacional, TV Paulista). Toni, após ter estudado composição com Guarnieri e Koellreutter, torna-se regente, compositor e professor; esmera-se em criar espaços para a música em São Paulo funda o Departamento de Música da Universidade de São Paulo (1970), a Escola Municipal de Música de São Paulo (1969), bem como a Orquestra Sinfônica Jovem Municipal de São Paulo 
(1968; rebatizada como Experimental de Repertório), Orquestra de Câmara de São Paulo (1956 financiada por parcas doações de empresários. Os músicos dificilmente recebiam cachê pelos concertos; entre eles, Rogério Duprat, também membro da diretoria da orquestra) e as Orquestras Sinfônica e de Câmara da USP (OSUSP, 1972 e OCAM, 1995), além de idealizar e dirigir as edições do Festival de Música de Prados (início em 1977). O papel do maestro na constituição do Música Nova é fundamental não só por tê-los apresentado uns aos outros, mas pelo estímulo ao estudo de novas técnicas e propostas estéticas de compositores europeus alinhados à vanguarda e, sobretudo, pelo espaço efetivo à execução de novas obras, a Orquestra de Câmara de São Paulo, cuja proposta era a divulgação do repertório contemporâneo - ao contrário do que se passava com a Orquestra Sinfônica do Teatro Municipal, dirigida por Guarnieri, de repertório mais restrito. Em 1961, por ocasião da VI Bienal de São Paulo, apresenta a peça de Willy “Música para Marta”, assim como antes já havia executado músicas de Duprat e Gilberto.

No início da década de 1960, os três compositores conseguiram se descolar um pouco de sua dependência em relação aos círculos pecebistas afeitos ao folclorismo para a execução e legitimação de suas obras, além de começarem a participar das disputas sobre as diretrizes culturais do partido, no caso de Duprat. Este movimento ganhou impulso pela "união" de compositores, poetas e artista, aliados na disputa partidária contra a geração que os antecedeu. $O$ ponto de vista comum era a descrença ante as possibilidades estéticas do nacionalismo, de direita e de esquerda, e a busca pela atualização da linguagem musical. "Gilberto Mendes redefine então, sob a ótica do grupo de vanguarda, o que seria a "arte nacional": "Para aceitar a diferenciação entre música nacional e universal, eu diria que quanto mais inventiva, sem ligações com qualquer tradição, mais nacional é a música” (Gilberto Mendes em entrevista apud ZERON, 1991:58). Este impulso expressivo resultado de tensões sociais se formalizou entre os compositores nos termos da questão crítica sobre a memória do material musical. Ora sob orientação de Olivier Toni, ora estudando partituras que traziam de viagens à Europa, pesquisam avidamente os procedimentos e técnicas, bem como a fundamentação de novos problemas composicionais, da tradição serialista europeia e a produção de John Cage. Compõem vários exercícios de música serialista e aleatória e participam de experiências de formação em Darmstadt. Buscavam a internacionalização da arte desenvolvida no Brasil e conseguem reconhecimento de estrangeiros - têm suas músicas tocadas e partitura editadas na Bélgica, Alemanha e Holanda. Junto a isso, era imprescindível realizar a total ruptura com o passado da música brasileira erudita e pensá-la numa "linha evolutiva da linguagem da música ocidental", conforme palavras de Haroldo de Campos (em seu livro O balanço da Bossa e outras bossas, em que alinha vanguarda europeia, bossa nova e tropicalismo). Este discurso autojustificativo, que lembra algumas das principais ideias dos poetas concretistas, está presente no 
manifesto lançado em 1963, "Música Nova - Compromisso total com o mundo contemporâneo". As semelhanças com as ideias concretistas vão além da citação comum da frase de Maiakóvski em seus respectivos manifestos (“sem forma revolucionária não há arte revolucionária”): ambos reafirmam suas fontes de inspiração estrangeiras, seu atributo inovador, a atualização da linguagem em seu contexto de autonomização, a preponderância do trabalho sobre a forma (que se retraduz na música como a superação da supervalorização do parâmetro melódico), etc. Não à toa, muitas das obras compostas pelo grupo na década de 1960 são elaborações sobre textos poéticos de Décio Pignatari, ou dos irmãos Campos. Nessa linha encontramos de Gilberto Mendes "Nascemorre" (1963), sobre poema de Haroldo de Campos e "Motet em Ré menor" (“Beba Coca-Cola”), sobre poema de Décio Pignatari; "Um movimento" (1962) de Willy Corrêa de Oliveira sobre poema de Pignatari; “Organismo" (1961) de Rogério Duprat, também sobre poema de Pignatari, e vários outros exemplos. Todos têm suas estruturas derivadas dos poemas, procedimento que se convencionou chamar de "isomorfismo", em que a forma de uma obra é construída em referência semântica a outra obra. Por um lado, esta foi a solução formal para o problema das origens e memórias do material: como os compositores do Música Nova não podiam recorrer a nenhum tipo de material que se associasse ao folclorismo dos nacionalistas, deveriam eles mesmos "forjar" sua base, aos moldes do que as correntes serialistas desde Schoenberg realizavam ao propor que o material composicional seja "desnaturalizado", chegando à generalização paramétrica com a serialização integral de Boulez, Pousseur e Stockhausen, isto é, de todos os parâmetros da música (timbre, intensidade, alturas, durações, registros). As séries são a base do material.

Este processo de extrema depuração formal do material é reveladora do intento de fazê-lo de tabulae rasae, no sentido se eliminar qualquer relação com o passado, “apontando tanto para uma perspectiva afirmativa do presente, quanto para um projeto de exclusão (feitas as exceções assinaladas) de contribuições realizadas no mesmo campo criativo” (ARRUDA, 2001: 339). Ao serialismo, que começa a ser criticado por Duprat, incorporam-se outros elementos de expansão do universo sonoro: pesquisa de sons "alternativos" (ruídos, microtons, eletrônicos); cruzamento com outras linguagens expressivas (teatro, poesia, artes visuais, etc) e busca por grafias alternativas à notação tradicional. Aos poucos, distanciam-se da ortodoxia serial e as músicas tornam-se mais abertas, inclusivas em sua construção. Cada música começa a propor seu próprio código particular e específico em busca de uma abertura da forma que leve à plasticidade das decisões pelo intérprete, que seguindo indicações, deve propor soluções para a obra durante a execução (algo como uma improvisação orientada).

No entanto, os compositores se decepcionam com a falta de circulação, receptividade e público para suas experimentações apresentadas nas edições anuais do Festival de Música Nova 
(organizado por Gilberto Mendes até hoje) e na VIII Bienal de Arte de São Paulo, em 1965 no Teatro Municipal. Neste último episódio foram rechaçados pelo público. As diferenças entre os compositores, mais do que os fatores de agregação, acirravam-se de tal forma que redunda na cisão do Música Nova: de um lado Rogério Duprat e Damiano Cozzela, de outro Willy Corrêa. Do ponto de vista estético, a polarização era entre aqueles que estavam mais interessados na "desestruturalização" pensada por John Cage da forma face ao extremo rigor dos procedimentos serialistas e estes, tributários dos problemas de Boulez, Pousseur e Stockhausen (Willy ainda intercedia em favor de questões não superadas da fatura serialista). Do ponto de vista "político", Duprat e Cozzella defendiam a integração do compositor ao mercado de consumo a fim de ganhar público e sair do hermetismo pelo qual enveredavam; posição rejeitada por Willy e Gilberto Mendes.

Além da movimentação no espaço partidário, outro fator importante para o estabelecimento dessa fase de experimentações dos compositores foi a boa colocação que alguns auferiram no mercado publicitário, produtoras de filmes e canais de rádio e televisão. Assim mantiveram meios de sustento independentes dos restritos espaços institucionais, que não abrigavam qualquer tipo de compositor - neste sentido, a fundação dos Departamentos de Música da USP e da UNICAMP em 1970 foi decisiva à profissionalização da composição erudita, sobretudo de suas correntes experimentais. Duprat e Cozzella estiveram ligados a uma firma comercial de "produção de qualquer coisa que dependesse de som”, a Audimus Ltda.; depois Cozzella se volta ao ensino, enquanto Duprat funda seu próprio estúdio, o Vice-Versa (cf. GRAÚNA, 2002:200). Ambos ganham a vida como arranjadores de música popular. Aliás, Rogério Duprat é certamente mais conhecido pelos seus trabalhos de arranjo para os tropicalistas e por suas trilhas sonoras para filmes do que por peças junto ao Música Nova. No entanto, seus planos não pareciam ser esses, pois no ano de 1965 sua vida passa por transformações drásticas (idem:200-202). Com a intervenção do regime militar na Universidade de Brasília, onde trabalhou por poucos anos junto a Cláudio Santoro, seu ex-professor de composição, se viu obrigado a deixar a instituição com mais duzentos professores em sinal de protesto contra a repressão. Até então, sustentava planos de vida na academia (como a montagem de um laboratório sonoro para experimentações eletroacústicas, um centro de pesquisas fonológicas e um programa de divulgação da música contemporânea para a TV de Brasília). De Brasília volta a São Paulo, onde se vê desempregado e morando com a mãe de favor. Sem perspectivas de voltar aos espaços acadêmicos, volta-se ao mercado fonográfico exclusivamente. Paralelamente à busca de emprego, isto é, de sobrevivência, deixa de buscar o novo e se desentusiasma com a militância no PCB, tornando-se descrente em relação aos princípios defendidos pelas vanguardas artísticas. Outra razão de seu desinteresse pela composição de obras 
eruditas foi o fato de que elas dificilmente seriam executadas novamente, porquanto o novo contexto político desfavorável exigisse constantes "jogos políticos" para os quais não se dispunha. “Não tinha o mínimo de paciência para fazer parte dos 'esquemas', conchavos e 'politiquinhas' para que os regentes viessem a tocar a minha música” (Entrevista, 1998 apud GAÚNA, 2002: 202). Em 1966 isso o levou à dedicação integral por dezessete anos à música popular, onde alcança notoriedade e prestígio, e à reformatação do discurso estético e político - critica a cultura com "K" maiúsculo, afirma a paridade entre música popular e erudita constantemente e defende a integração do músico na sociedade de consumo como possibilidade a ser seguida (postura vista com desprezo por Willy e com certa desconfiança por Gilberto).

Willy estava em dificuldades para sustentar sua família pelos pouco rendimentos provenientes da composição e, logo no início dos anos 60, começa a fazer música para filmes, televisão e jingles publicitários. em 1966 começa a dirigir e musicar filmes na Jota Filmes; foi professor na Escola Superior de Propaganda, tornou-se diretor da J. Walter Thompson e, mais tarde, diretor do departamento de filmes e televisão da agência M. Salles; em 1969 abandona a carreira publicitária após um colapso nervoso. Mostra-se contrário a associar seus trabalhos publicitários e da área de cinema ao corpo "legítimo" de suas obras. Em 1970, a convite de Olivier Toni, torna-se professor do Departamento de Música da USP, onde trabalha até sua aposentadoria. Nota-se que suas mudanças de posição estética são bastante intensas, como quando queima sua produção "nacionalista" e, mais tarde, passa pelo conturbado processo de abandonar a vanguarda e aderir aos preceitos da música engajada - rompendo com seus amigos concretistas publicamente.

Quanto a Gilberto Mendes, colaborou igualmente em agências publicitárias e viveu como bancário da Caixa Federal até Olivier Toni o convidá-lo a lecionar no Departamento de Música da USP, da mesma forma que Willy (ZERON, 1991:55). Nos três compositores percebemos certo processo de apagamento e revisão, nos anos 70, do que não lhes parecia “ilegítimo" em suas trajetórias: no caso de Duprat, de seu passado "vanguardista-elitista", visto que se estabelece nos meios da música popular; no caso de Willy e Gilberto, seu passado nacionalista e suas atividades publicitárias. Até mesmo a experiência do Música Nova é posteriormente criticada por Willy - o fetiche pelo novo e a vontade de fazer do material uma folha em branco, algo desprovido de memória; bem como a noção de progresso linear da linguagem musical defendida por parte da vanguarda - em favor de uma música engajada que evidenciasse a memória histórica do material.

Neste sentido, sua peça “Adagio", de 1973, ilustra o início da revisão feita pelo compositor da questão histórica do material no período de sua transição estética da vanguarda à música engajada. É patente a influência do pensamento de Henri Pousseur, palestrante de várias edições dos cursos de verão de Darmstadt, neste resgate do material como tabulae scriptae (cf. BONIS, 2012). 
Pousseur, em resposta à controvérsia com Pierre Boulez sobre a inviabilidade do recurso da citação, rebate a posição do colega em seu texto Composer (avec) des identités culturelles, no qual desdobra seu argumento a favor do recurso em seis pontos, discorrendo sobre as condições de descontextualização e recontextualização do objeto citado. Em relação à contestação da possibilidade de combinar o impulso contemporâneo pela organicidade a um material historicamente reconhecível, Pousseur reafirma a validade do diálogo com músicas preexistentes desde que observada a "costura" em um todo orgânico, prevendo assim a necessidade de um sistema subjacente para assegurar a coerência dos elementos associados (cf. BONIS, 2006:823). Tais possibilidades discursivas discutidas por Pousseur orientam fortemente os trabalhos de Willy, isto é, sua manipulação estrutural e semântica dos objetos citados.

Segundo Bonis (em entrevista concedida a Ligia Amadio em 2009), fruto de reflexão sobre os movimentos lentos das sinfonias de Mahler - que, por sua vez, também traz a consideração histórica, recorrendo a citações quase literais da tradição da música orquestral barroca, clássica e romântica - observa-se na obra "Adagio" o emprego do procedimento metalinguístico da citação, contemplada pelo compositor como uma operação semântica no contexto da ausência de linguagem comum, em um momento em que se faz marcante a consciência histórica da música erudita. Considerando-se o trabalho do material pela ressignificação de suas fontes, pode-se localizar a intencionalidade política do compositor, oculta nos interstícios do material com que ele lida e na maneira de manipulá-lo. Nesse procedimento encontra-se uma proposição geral que é válida tanto para a "fase" vanguardista, por meio de certa compreensão do discurso musical derivada da semiologia, como para sua "fase" engajada, na qual busca nas propostas estético-políticas de Hans Eisler e Bertold Brecht a ideia de que a obra artística "não é obra, mas aparelho, instrumento. E quanto mais elevada for, mais suscetível de formulação, desmontagem e transformação (...). A maior exigência que se faz ao texto (...) é sua citabilidade” (BENJAMIN, 1986:124).

Sendo o material oriundo de uma determinada herança cultural, a citação comprova-a como texto principal, ao ser tratada como uma referência valorizante, ou se explicarem mutuamente numa relação interna em que a transmissibilidade da herança exige sua citabilidade. Nesse sentido, a citação operaria como a recontextualização de um significado: a paródia e a sátira como o "outro" do texto parodiado ou satirizado; a alegoria como um dizer o "outro" dentro de um contexto que lhe é originalmente estranho; a referência como a recontextualização do "mesmo”, etc. Isso quer dizer que a citação não se prestaria apenas à designação exterior de uma identidade, senão que também opera enquanto elemento metalinguístico estruturante. Pode fazer recurso tanto a uma referência histórica já instituída, quanto à ressignificação paralela desse fato na presentificação de uma imagem reconstruída do 
passado. Dessa forma, nomear - através da citação como forma de tratar o passado - significa recuperar uma determinada experiência histórica, presentificando-a na manipulação dos seus dados constituintes. Coloca-se a relação herança/memória a serviço do presente, atualizando essa experiência, suscetível de ser revivida num processo de (re)fundação contínua desse presente. (...) Por isso mesmo, o passado adquire autoridade aos olhos do presente ao ser transmitido como repositório ou consolidação de uma experiência coletiva, por este recuperada.(ZERON, 1991:343344)

Especificamente sobre o "Adagio", segundo Bonis, mais ou menos no meio, numa espécie de clímax dramático da peça, surge nos contrabaixos a marcha do início da "6a Sinfonia" de Mahler; marcha que, por sua vez, já era inspirada em "Manfred" de Schumann. Este fato é revelado no "Adagio" pois há uma sutil transição do motivo da marcha para um tema melódico da abertura de "Manfred". Ao final deste curto trecho, há a superposição de duas linhas melódicas, cada uma derivada das duas peças citadas, que se batem e terminam num choque intenso de $2^{\mathrm{a}}$ menor no registro agudo dos violinos - como que representando o c onflito entre as duas fontes; entre a referência histórica e a reflexão sobre a referência histórica que Mahler coloca. Há outros trechos também com figurações de Schumann que atravessam as cordas, dos graves aos agudos, entremeadas por outras figuras orquestrais referentes a outras peças citadas por Mahler na "6 Sinfonia". Ademais, Willy monta um conjunto orquestral para o "Adagio" de maneira a selecionar texturas, implicando possibilidades inusitadas de timbres. A m ontagem do na ipe de cordas, um desafio ao compositor que tem a intenção de driblar sua forte associação a c erta ressonância tonal das alturas, é pensado de acordo com expressivo trabalho timbrístico. Isso se manifesta na procura de efeitos e figuras deste parâmetro, as mais inusitadas, para cada um dos naipes de cordas. Unificando todos esses materiais tão díspares há uma estrutura de alturas derivadas das citações. Existe no começo da peça dois momentos em que um acorde faz um pano de fundo e acontecem colorações com os sopros e trêmulos de cordas. Acontece num primeiro momento com o naipe completo das cordas e, depois de uma intervenção dos metais, surge novamente o acorde como pano de fundo; primeiro com as cordas solistas e depois com os naipes completos. Os dois acordes funcionam como panos de fundo para pontilhismos de madeiras e metais, cada um baseado numa estrutura de alturas extraídas das peças citadas. Bonis afirma que Willy se serve da uma estrutura de

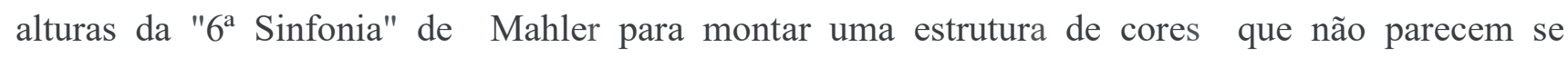
relacionar com a peça de Mahler, e o mesmo se daria com a citação de Schumann - donde deduz uma estrutura de alturas que unificaria harmonicamente os dois compostos. Ou seja, o que pareceria um tanto chocante, o surgimento da citação e seu fim, na verdade teria unidade na estruturação das 
alturas, algo comum à preocupação de Willy na vanguarda, de construir um conjunto orgânico garantidor da coesão interna da peça. Com efeito, a preocupação com a memória da história da música é também refletida numa preocupação com a memória interna do discurso, com a coerência interna do discurso, com a memória do material.

Desta forma, pode-se concluir que os deslocamentos de posição estética dos três integrantes do grupo entre os polos internos da vanguarda, da extrema experimentação formal e atualização da linguagem à valorização da história e memória do material - apesar de no "Adagio" estar quase irreconhecível para a maior parte do público por ser esta uma peça do período em que Willy ainda não havia rompido com a vanguarda - fundamenta-se no horizonte de possibilidades de inserção de seus trabalhos musicais em espaços de apreciação, tanto quanto da busca incessante de meios de sustento e financiamento da atividade musical. O contexto musical dos anos de 1950 e 1960, até a criação dos departamentos de música das universidades públicas paulistas, era de difícil acesso aos compositores que não estivessem dispostos a acatar a diretriz cultural partidária nacional-folclorista, ou o nacionalismo de Estado vigente nas mais antigas instituições de ensino e divulgação de repertório. Sobrou-lhes o espaço dos mercados culturais, onde podiam tanto financiar seus festivais de pequeno porte e cindir seus trabalhos entre "música de mercado", "música de vanguarda" e "música engajada", quanto abrir mão da circulação nos espaços da vanguarda e se dedicar à música popular, trilhas sonoras, jingles, etc. 


\section{CONCLUSÃO}

Ao longo deste trabalho, passamos em revista o processo de institucionalização do meio da música de concerto em São Paulo no período entre 1920 e 1950, a partir de seus efeitos nas trajetórias de alguns compositores que se engajaram na construção de um projeto modernista de música junto ao grupo de intelectuais. Abordamos o itinerário de Camargo Guarnieri, as condições de possibilidade para que se tomasse compositor, ensejasse formação e aprendizado do métier, arranjasse colocações profissionais e se consagrasse, tanto no Brasil como no exterior. Ficou claro que os círculos de sociabilidade em que os intelectuais modernistas se movimentavam desde o surgimento das propostas de renovação simbólica e atualização artística na década de 20 , com a Semana de Arte Moderna de 22, teve papel fundamental na criação dessas condições. Com o capital social acumulado dos contatos com as elites oligárquicas, os intelectuais conquistaram posições no campo de poder e, assim, puderam operacionalizar seu projeto de avanço da institucionalização da música. Tal se deu com a criação do Departamento de Cultura, em 1935, durante a gestão de Fábio Prado, capitaneada por Mário de Andrade.

Verificamos que o ingresso dos intelectuais no Estado na década de 30 só foi possível graças à mudança de correlação de forças nas disputas internas às elites ligadas ao PRP - donde se originou o Partido Democrático e suas lideranças intelectuais associadas aos círculos modernistas. A crise cafeeira e a d errota do movimento constitucionalista implicou a d errocada das antigas lideranças das classes dirigentes, e provocou a ascensão dos intelectuais do PD a cargos do estado maior paulista na última metade de década de 30. Tais colocações foram fruto da combinação entre os projetos dos modernistas e dos dirigentes paulistas interessados em reaver a antiga hegemonia paulista no âmbito nacional. Portanto, a gestão de Mário de Andrade a frente dos órgãos culturais almejava aplicar um plano de modernização local que, logo menos, deveria ser uma espécie de laboratório para o país. Embora os modernistas quisessem alçar a cultura a m otor central da transformação da sociedade, a mediação política a que deviam as condições de implementação de seus planos não deixou de impregnar sua operação e seu legado.

ação de agentes em tomo da música de concerto, deu-se notadamente a partir dos primeiros esforços de criação de instituições de formação e difusão musical no século XIX, pelo Império. Da relativa dificuldade em manter conjuntos musicais fixos e cen tros de ensino musical que dessem conta da formação requerida para a constituição de uma geração de compositores que não dependessem de atividades nos meio da música de divertimento associada aos espaços de sociabilidade ora da elite, ora de setores populares, advém um cenário que se manteria até meados da década de 1930. No contexto da transição entre a Primeira República e a Era Vargas, surgem 
projetos concretos de dinamização da vida musical em centros de crescente urbanização, como São Paulo, Rio de Janeiro e Porto Alegre. Tais projetos foram engendrados por círculos de intelectuais e artistas que, nos anos 1920, estiveram à f rente de agitações culturais fomentadas por elites oligárquicas desejosas de empreender um contraditório processo de modernização do pa ís. Com efeito, o que eram críticas à desatualização cultural brasileira e à subordinação dos artistas do XIX à estéticas relacionadas ao complexo do colonizado na década de 1920, passa a es truturar um largo plano de políticas públicas às artes com o ingresso dos intelectuais modernistas em instância de poder.

A partir da década de 1930, em São Paulo, cidade privilegiada no recorte espacial desta pesquisa, o engajamento no âmbito municipal do D epartamento de Cultura operado por Mário de Andrade lança as bases da ampliação do processo incipiente de institucionalização e diferenciação das atividades musicais. Através de várias iniciativas logra conferir maior vitalidade ao meio musical, sendo fundamental neste processo, além das iniciativas institucionais, a colaboração estabelecida com jovens músicos que intentavam viabilizar carreiras na área de criação musical. Dessas relações de interdependência entre compositores e i ntelectuais modernistas, crivadas por tensões, divergências, apoio contingencial, rupturas, etc, gesta-se a dinâmica do m odernismo musical. Os músicos não seriam meros agentes passivos operadores das mudanças almejadas, uma vez que eles próprios tinham seus projetos estéticos, mas ativos formuladores do m odernismo, porquanto tinham de colocá-lo em prática; seja elegendo do arcabouço construído pelos intelectuais de tradições brasileiras legítimas elementos expressivos que deveriam ser formalizados em peças, seja na condução dos órgãos musicais dos quais forma incumbidos.

O texto Ensaio sobre a música brasileira, escrito em 1928 por Mário de Andrade é comumente considerado um guia de orientação estética à criação da música verdadeiramente brasileira, sobretudo em relação ao material musical. Isto é, aquela distante tanto do g osto "cosmopolita" por óperas italianas da elite oligárquica paulistana, quanto despida de exotismos e lugares-comuns, aos quais Villa- Lobos incorria, segundo o autor. Pode-se, todavia, entrever no texto um intento mais amplo e ambicioso, qual seja, a i nserção da música erudita num projeto de construção nacional do Brasil, assim como diretrizes para um projeto de "modernização" do m eio musical, prevendo a urdidura de referenciais à música brasileira a partir de suas tradições. Para tanto, além de fomentar instituições de formação e d ivulgação de repertório e garantir a profissionalização de criadores e i ntérpretes, trata-se de formar um grupo de compositores "modernos", norteados por questões estéticas da fonte do material musical. Fica claro, portanto, que desde o i nício o e nsejo de modernizar o m eio musical esteve vinculado ao projeto de forjar um conjunto de representações sociais emblemáticas do nosso, de uma tradição brasileira a ser 
inventada pelos próprios modernistas a partir da eleição de elementos legítimos das produções musicais "populares" de regiões interioranas, num primeiro momento, do país. Tais representações sociais orientam a escolha das fontes "folclóricas", termo que se cristaliza no meio musical da época, entre os compositores e intelectuais.

Apesar do substrato institucional do c ampo musical ter se ampliado, a gestão de Mário de Andrade não foi suficiente para garantir as condições necessárias à formação de compositores, nem de manter a p rofissionalização da música de concerto - um tanto limitada à nomeações de compositores para dirigirem os novos conjuntos musicais criados, e ingressarem no quadro docente do Conservatório Dramático Musical. A dependência do pr ojeto modernista em relação aos desenlaces dos conflitos e disputas do c ampo político conformou os rumos dos principais compositores brasileiros da época, conforme veremos no pr imeiro capítulo. Em comum às trajetórias, por conta do atrelamento ao campo do pode r, passível de fragilizar as condições de auferimento de colocações no campo musical, fica em evidência a necessidade de estabelecer redes alternativas de colaboradores, vinculados a outras instâncias de poder e sociabilidade, nacionais e internacionais.

Pretendo, com efeito, traçar os possíveis caminhos dos compositores eruditos em São Paulo, sempre trilhados a fim de buscar condições de formação musical e viabilização da obra. Entre as décadas de 1930 e 1960, o polo erudito do c ampo musical ganha corpo institucional em relação às condições que Carlos Gomes, Henrique de Mesquita e Francisco Braga encontraram no século XIX e início do XX. Tais décadas representam um marco na dinamização do meio da música de concerto no Brasil com a criação de uma rede de instituições de difusão e formação, transição operada pela estruturação do mecenato oficial encarnada nas políticas públicas para a ar te do getulismo, bem como, no âmbito paulista, da direção de Mário de Andrade no Departamento de Cultura da prefeitura. Esta rede de instituições, mantida sob a guarida do Estado e gerida pela dinâmica que se depreende das relações de interdependência entre intelectuais dos círculos de poder e os músicos encarregados, realiza a implementação do projeto do mecenato estatal. Contudo, nitidamente atravessado pelas tensões entre os intelectuais e músicos, pois estes também partilhavam de poder, ao passo que ensejavam se afirmar como artistas e realizar a contento seus projetos estéticos, e por vezes políticos, o espaço institucional criado abre novas possibilidades de posições no c ampo musical, novos caminhos possíveis aos compositores. Entre tais possibilidades surgem as primeiras experiências especulativas de vanguarda, ao final da década de 1930, interessadas em repensar o material musical e sua fonte folclórica, movimento que entraria em choque com parte dos compositores estabelecidos. As experiências dos grupos de compositores como o pioneiro Música Viva, de meados da década de 1930 e de 1940, e o Música Nova de 1963, fixaram na história do 
campo as primeiras reelaborações e rupturas com as preocupações do modernismo musical de Mário de Andrade. Do primeiro para o s egundo grupo, como veremos, há grandes diferenças institucionais e a extensão dos trabalhos de produção para o ambiente do mercado publicitário, bem como da música popular.

Pensei, portanto, em organizar a dissertação em três capítulos, um para cada experiência dos grupos de compositores tidos, conforme discutido, como fundamentais à formação do polo erudito do campo musical brasileiro, seguindo a ordem cronológica de seus inícios:

No primeiro capítulo pretendo destrinchar alguns dos aspectos decisivos à trajetória de compositores bem-sucedidos que encontraram no âmbito do Estado o caminho para a viabilização de seus projetos artísticos. Neste sentido, Camargo Guarnieri é t omado como ilustração bastante representativa dessa figura, ao ser cotejado com outras trajetórias de compositores paulistas em suas respectivas tentativas de lograr boa formação técnica e colocações profissionais num meio musical marcado pela precária institucionalização do ensino e indiferenciação entre as diversas atividades musicais empreendidas no $\mathrm{m}$ ercado popular de divertimento. Limitando-me ao período compreendido entre as décadas de 1920 e 1950, da gestação e implementação do projeto modernista dirigido à música, destacarei alguns elementos característicos do campo musical da época, especificamente do polo erudito. Tal caso será examinado à luz de suas redes de relações estratégicas e interdependências com os patronos do Estado, o c írculo modernista estabelecido na imprensa e em órgãos públicos e até mesmo com a política de "boa vizinhança" orientadora do panamericanismo musical e respaldada pelos interesses do mercado da música sinfônica dos Estados Unidos. Este capítulo é o m ais desenvolvido neste texto de qualificação, de forma que pretendo ainda completá-lo com estudos sobre aspectos musicais de cada período, para além dos poucos momentos em que aparecem no atual capitulo. Ainda faltaria, a meu ver, um último item a respeito do esforço de Guarnieri, durante a década de 1950, de formar uma escola de composição, já que as preocupações com um legado a ser deixado parecem acometê-lo de forma mais peremptória nesse período. 


\section{BIBLIOGRAFIA}

\section{Fontes de Pesquisa}

Correspondência:

Fundo Camargo Guarnieri, Arquivo do Instituto de Estudos Brasileiros (IEB-USP)

- Correspondência recebida e enviada entre Camargo Guarnieri e as seguintes pessoas:

- Abreu, Maria

- Azevedo, Luiz Heitor Correa de

- Baldi, Lamberto

- Copland, Aaron

- Koechlin, Charles

- Seeger, Charles

- Smith, Carleton Sprague

\section{Bibliografia de fontes primárias - testemunhos, memórias, biografias, correspondência, análise de obras, história da música}

- ABREU, Maria. "Camargo Guarnieri - o homem e episódios que caracterizam sua personalidade". In SILVA, Flávio (org). Camargo Guarnieri - o tempo e a música. Rio de Janeiro/São Paulo: Funarte/Imprensa Oficial, 2001.

- ANDRADE, Mário. Ensaio sobre a música brasileira. São Paulo: Martins, 1972.

- _ . Música, doce música. São Paulo, Martins, 1963.

- AZEVEDO, Luiz Heitor Correa de. 150 anos de música no Brasil: 1800-1950. Rio de Janeiro: José Olimpio, 1956.

- ___ . "Si alza la tela". In. A parte do anjo, autocrítica de um cinquentenário. São Paulo: E. S. Mangione, 1947.

- BELARDI, Armando. Vocação e arte: memórias de uma vida para a música. São Paulo: Casa Manon, 1986.

- BONIS, Maurício de. Tabulae scriptae: a metalinguagem e as tragetórias de Henri Pousseur e Willy Corrêa de Oliveira. Tese de Doutorado. CMU-ECA-USP, São Paulo, 2012.

-__ . . O Misere de Willy Correa de Oliveira: “aporia” e "apodítica”. Dissertação de mestrado. CMU-ECA-USP, São Paulo, 2006.

- BRITO, Teca Alencar. Koellreutter como educador. O humano com objetivo da educação musical. São Paulo: Peirópolis, 2001.

- CASTRO, Marcos Câmara de. Fructuoso Vianna, orquestrador do piano. Rio de Janeiro: Academia Brasileira de Música, 2003.

- DUARTE, Paulo. Mário de Andrade por ele mesmo. São Paulo: Hucitec, 1977.

- FRANÇA, Eurico Nogueira. Memórias de Vera Janacópulos. Rio de Janeiro: Ministério da Educação, 1959.

- GAÚNA, Regiane. Rogério Duprat: sonoridades múltiplas. São Paulo: Unesp, 2002.

- KATER, Carlos. Eunice Katunda: musicista brasileira. São Paulo: Annablume, 2001 a 
Atraves/Musa, 2001b

- KIEFER, Bruno. Mignone, vida e obra. Porto Alegre: Editora Movimento, 1983.

- MARIZ, Vasco. História da música no Brasil. Brasília: MEC, 1981.

-___ (org.). Francisco Mignone, o homem e sua obra. Rio de Janeiro: Funarte/Editora UERJ,1997

-MEDAGLIA, Júlio. Música impopular. São Paulo: Global, 1988.

- MENDES, Gilberto. Uma odisséia musical: dos mares do sul à elegância pop/art déco. São Paulo: Edusp, 1994.

- MigONE, Francisco. A parte do anjo, autocrítica de um cinquentenário. São Paulo: E. S. Mangione, 1947.

- ORSINI. Maria Stella. Guiomar Novaes: uma arrebatadora história de amor. São Paulo: C.I., 1992.

- OLIVEIRA, Willy Corrêa. Beethoven: proprietário de um cérebro. São Paulo: Perspectiva, 1979

- _ . Cadernos. Tese de Doutorado. ECA-USP, São Paulo, 1998.

- _ Cinco advertências sobre a Voragem. São Paulo: Luzes no Asfalto, 2010.

- SOUZA LIMA, João de. Moto Perpétuo. A visão poética da vida através da música. São Paulo: IBRASA, 1982.

- SILVA, Flávio (org). Camargo Guarnieri - o tempo e a música. Rio de Janeiro/São Paulo: Funarte/Imprensa Oficial, 2001.

- TAGLIAFERRO, Magdalena. Quase tudo...(Memórias). Rio de Janeiro: Nova Fronteira, 1979.

- TONI, Flávia C; SILVA, Flávio. "Parte II. Correspondência Camargo Guarnieri - Mário de Andrade" In. Camargo Guarnieri - O tempo e a música. Rio de Janeiro/São Paulo: Funarte/Impresa Oficial, 2001.

- VERHAALEN, Marion. Camargo Guarnieri: Expressões de uma vida. São Paulo: Edusp/ Imprensa Oficial, 2001.

- WERNET, Klaus. Camargo Guarnieri: memórias e reflexões sobre a música no Brasil. Dissertação de Mestrado. São Paulo, CMU-ECA-USP, 2009.

- WISNIK, José Miguel. O coro dos contrários - a música em torno da Semana de 22. São Paulo: Duas Cidades, 1977.

\section{Bibliografia de referência}

- ARAgÃO, Pedro de Moura. Luiz Heitor Correa de Azevedo e os estudos de folclore no Brasil: uma análise de sua trajetória na Escola Nacional de Música (1932-1947). Dissertação de Mestrado. Rio de Janeiro, EM-UFRJ, 2005.

- ARRUDA, Maria Arminda do Nascimento. Metrópole e cultura. Bauru: Edusc, 2001.

- BARBATO JR, Roberto. Missionário de uma utopia nacional-popular: os intelectuais e o Departamento de Cultura de São Paulo. São Paulo: Annablume/FAPESP, 2004.

- BESSA, Virgínia de Almeida. A cena musical paulistana: teatro musicado e canção popular na cidade de São Paulo (1914-1934). São Paulo, FFLCH-USP, 2012.

- BINDER, Fernando. "Mulheres e imigrantes: invisibilidades históricas e as práticas da música culta em São Paulo na Belle Époque”. Apresentação Oral. SIMPEMUS-UFPR, 2013.

- BOURDIEU, Pierre. As regras da arte. São Paulo: Cia das Letras, 1996

- BUSCACIO, César. Americanismo e nacionalismo musicais na correspondência de Curt Lange e Camargo Guarnieri (1934-1956). Tese de Doutorado. Rio de Janeiro, IFCS-UFRJ, 2009.

- CARVALHO, Dalila Vasconcellos de. O gênero da música: a construção social da vocação. São Paulo: Alameda, 2012.

- CHERÑAVSKI, Anália. Um maestro no gabinete: música e política no tempo de Villa-Lobos. 
Dissertação de Mestrado. Campinas, IFCH-UNICAMP, 2003.

- DASSIN, Joan. Política e poesia em Mário de Andrade. São Paulo: Duas cidades, 1978.

- EGG, André Acastro. Fazer-se compositor: Camargo Guarnieri (1923-1945). Tese de Doutorado. São Paulo, FFLCH-USP, 2010.

- _. O debate no campo do nacionalismo musical no Brasil dos anos 1940 e 1950: o compositor Guerra-Peixe. Dissertação de Mestrado. Curitiba, DH-CHLA-UFPR, 2004.

- ELIAS, Norbert. Estabelecidos e outsiders. Rio de Janeiro: Zahar, 2000.

- _ _ . Mozart, sociologia de um gênio. Rio de Janeiro: Zahar, 1995.

- $\quad$. A sociedade de corte. Rio de Janeiro: Zahar, 2001

- FONSECA, Denise Sella. Uma "colcha de retalhos”. A música em cena em São Paulo entre o final do século XIX e início do XX. Dissertação de Mestrado. São Paulo, FFLCH-USP, 2014.

- GROSSI, Alex Sandra de Souza. O idiomático de Camargo Guarnieri nos 10 improvisos para piano. Dissertação de Mestrado. São Paulo, CMU-ECA-USP, 2002

- GUÉRIOS, Paulo Renato. Heitor Villa-Lobos: o caminho sinuoso da predestinação. Curitiba: Edição do autor, 2009.

- IKEDA, Alberto. Música na Cidade em Tempo de Transformação: São Paulo, 1900-1930. São Paulo, ECA-USP, 1989a.

- _ Italianos e a música em São Paulo" In. O Estado de S. Paulo, Suplemento Literário. São Paulo, 7/janeiro, nº442, ano VII, 1989b.

- KOBAYASHI, Ana Lúcia M. T. A escola de composição de Camargo Guarnieri. Dissertação de Mestrado. São Paulo, PPGM-IA-UNESP, 2009.

- MICELI, Sérgio. "Intelectuais e classe dirigente no Brasil (1920-1945)" In. Intelectuais à barsileira. São Paulo: Companhia das Letras, 2001.

- _. Nacional estrangeiro: História social e cultural do modernismo artístico em São Paulo. São Paulo: Companhia das Letras, 2003

- NOGUEIRA, Antônio Gilberto. Por um inventário dos sentidos: Mário de Andrade e a concepção de inventário. Tese de Doutorado. São Paulo: PUC, 2002.

- OLIVEIRA, Francini Venâncio de. Sejamos todos musicais: modernismo, música e política na crônica musical de Mário de Andrade (1938-1940). Dissertação de Mestrado. São Paulo, FFLCHUSP, 2005a.

$-$

"Intelectuais, cultura e política na São Paulo dos anos 30: Mário de Andrade e o Departamento Municipal de Cultura". In Revista Plural. São Paulo: Departamento de Sociologia, FFLCH-USP. 2005b, no 12, pp 11-19.

- OLIVEIRA, Lúcia. Estado Novo: ideologia e poder. Rio de Janeiro: Zahar, 1982.

- PINHEIRO FILHO, Fernando A. "Segall em São Paulo" e "A Sociedade Pró-Arte Moderna". In Lasar Segall: arte em sociedade. São Paulo, Cosac Naify/Museu Lasar Segall, 2008.

- QUINTERO RIVERA, Mareia. Repertório de identidades: música e representação do nacional em Mário de Andrade (Brasil) e Alejo Carpentier (Cuba). (décadas de 1920-1940). Tese de Doutorado. São Paulo, FFLCH-USP, 2002.

- RAFFAINI, Patrícia. Esculpindo a cultura na forma Brasil:o Departamento de Cultura de SP. São Paulo: Humanitas, FFLCH, 2001.

- ROSS, Alex. O resto é ruído: escutando o século XX. São Paulo: Companhia das Letras, 2009.

- RUBINO, Silvana. As fachadas da história: os antecedentes, a criação e os trabalhos do Serviço do Patrimônio Histórico e Artístico Nacional, 1937-1968. Dissertação de Mestrado. Campinas: IFCH/UNICAMP, 1992.

- SAPIRO, Gisèle. "La vocation artistique entre don et don de soi". In Actes de la recherche en Sciences Sociales. 2007/3, no 168, p. 4-11.

- SEVCENKO. Nicolau. Orfeu extático na metrópole: São Paulo, sociedade e cultura nos frementes anos 20. São Paulo, Companhia das Letras, 1992.

- SILVA, Flávio (org). Camargo Guarnieri - o tempo e a música. Rio de Janeiro/São Paulo: Funarte 
Imprensa Oficial, 2001.

- SOUZA, Carla Delgado de. Os caminhos de Gilberto Mendes e a música erudita no Brasil. Tese de Doutorado. IFCH-Unicamp, Campinas, 2011.

- TACUCHIAN, Maria de Fátima Granja. Panamericanismo, propaganda e música erudita: Estados Unidos e Brasil (1939-1948). Tese de Doutorado. São Paulo, FFLCH-USP, 1998.

- TOFFANO, Jaci. As pianistas dos anos 1920 e a geração jet-lag: o paradoxo feminista. Brasília: Editora UNB, 2007.

- TONI, Flávia. "Mon chèr élève: Charles Koechlin, professor de Camargo Guarnieri" In. Revista do IEB. São Paulo, nº . 45, pp 107-122, 2007

- _ . A missão de pesquisas folclóricas do Depto. de Cultura. São Paulo: CCSP, 1987.

- TRAVASSOS, Elizabeth. Os mandarins milagrosos: arte e etnografia em Mário de Andrade e Béla Bartók. Rio de Janeiro: Zahar, 1998.

- VINCI DE MORAES, José Geraldo. Metrópole em sinfonia. História, cultura e música popular na São Paulo dos anos 30. São Paulo: Estação Liberdade, 2000.

- _. Sonoridades paulistanas: a música popular na cidade de São Paulo - final do século XIX ao início do século XX. Rio de Janeiro: Funarte. 1995.

- WILLIAMS, Raymond. “A fração Bloomsbury”. In Revista Plural. São Paulo: Departamento de Sociologia, FFLCH-USP. 1999, $1^{\circ}$ sem. pp. 139-168.

- ZERON, Carlos Alberto de M. R. Fundamentos histórico-políticos da música nova e da música engajada no Brasil a partir de 1962: O salto do tigre de papel. Dissertação de Mestrado. FFLCHUSP, São Paulo, 1991. 